UNIVERSIDADE DE SÃO PAULO

FACULDADE DE EDUCAÇÃO

Luciara Batista Avelino

\begin{abstract}
O CONHECIMENTO TÁCITO E OS IMPEDIMENTOS EMOCIONAIS NO PROCESSO DE ENSINO/APRENDIZAGEM DE LÍNGUAS ESTRANGEIRAS
\end{abstract}


Luciara Batista Avelino

\section{O CONHECIMENTO TÁCITO E OS IMPEDIMENTOS EMOCIONAIS NO PROCESSO DE ENSINO/APRENDIZAGEM DE LÍNGUAS ESTRANGEIRAS}

Dissertação apresentada ao Programa de Pós-Graduação da Faculdade de Educação da Universidade de São Paulo como parte dos requisitos para a obtenção do título de Mestre em Educação.

Área de concentração: Educação, Linguagem e Psicologia.

Orientador: Prof. Dr. Nilson José Machado

Versão corrigida

São Paulo 
Autorizo a reprodução e divulgação total ou parcial deste trabalho, por qualquer meio convencional ou eletrônico, para fins de estudo e pesquisa, desde que citada a fonte.

Catalogação na Publicação

Serviço de Biblioteca e Documentação

Faculdade de Educação da Universidade de São Paulo

Catalogação da Publicação

Ficha elaborada pelo Sistema de Geração Automática a partir de dados fornecidos pelo(a) autor(a) Bibliotecária da FE/USP: Nicolly Soares Leite - CRB-8/8204

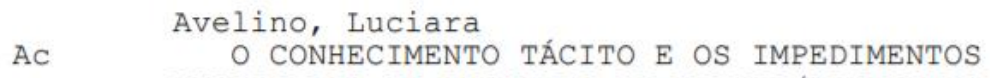




\section{FOLHA DE APROVAÇÃO}

AVELINO, L.B. O conhecimento tácito e os impedimentos emocionais no processo de ensino/aprendizagem de línguas estrangeiras. 2018. 97 f. Dissertação (Mestrado em Educação). Faculdade de Educação, Universidade de São Paulo, São Paulo, 2018.

Aprovado em:

\section{BANCA EXAMINADORA}

Prof. Dr. Nilson José Machado

Instituição Assinatura

Prof. Dr. Lino de Macedo

Instituição Assinatura

Prof. Dr. Eloísa Marques Miguez

Instituição Assinatura

Prof. Dr. Ana Paula Duboc

Instituição Assinatura

Prof. Dr. Cecília Canale Fornazieri

Instituição Assinatura

Prof. Dr. Marcia de Oliveira Cruz

Instituição Assinatura 
Aos educadores, uma pitada de entendimento no vasto plano encoberto do saber. DEDICO. 


\section{AGRADECIMENTOS}

Este trabalho não teria sido possível sem o apoio de vários indivíduos de extremo valor. Em primeiro lugar, o meu muito obrigada ao querido mestre Doutor Nilson José Machado pela nobreza de espírito, paciência e amizade nesses anos de mestrado.

Desejo igualmente agradecer ao psicanalista Norberto Keppe, pelo belo trabalho em prol da melhoria do ser humano e por fornecer instrumentos de uso prático para a nossa atividade cotidiana de educadores.

A Cláudia Bernhardt de Souza Pacheco, pela paciência, afeto, profissionalismo e por acreditar em mim. Nos trabalhos conjuntos, agradeço as oportunidades oferecidas e os caminhos trilhados com base no bem.

Ao meu querido companheiro César Soós, pelo carinho e apoio. E que, nas horas de dificuldade, sempre soube me incentivar com muito afeto.

Aos meus pais, por me terem dado educação, valores e apoio na trilha da minha vida. A meu pai (in memoriam), que, onde quer que esteja, nunca deixou de me amar, nem de confiar em mim. A minha mãe (in memoriam), que sempre teve confiança nas minhas virtudes.

A todos os meus familiares, irmãos, primos, tios, sobrinhos. Não citarei nomes, para não me esquecer de ninguém. Mas há aquelas pessoas especiais que diretamente me incentivaram com muita alegria.

A todos meus queridos amigos, especialmente de nossa escola, empenhados na formação de um grande time de trabalho para o bem! 
Às minhas amigas da USP Socorro Sarkis e Rosângela Medeiros, que foram decididamente importantes na minha vida acadêmica.

A todos os profissionais que, com seus respectivos trabalhos, permitiram esta obra.

A Deus, pela graça da vida e da possibilidade dessa maravilhosa coparticipação. 
"O mais importante é o conhecimento daquilo que impede o conhecimento." (KEPPE, 2001, p. 5) 
AVELINO, L.B. O conhecimento tácito e os impedimentos emocionais no processo de ensino/aprendizagem de línguas estrangeiras. 2018. 97 f. Dissertação (Mestrado em Educação). Faculdade de Educação, Universidade de São Paulo, São Paulo, 2018.

\section{RESUMO}

Esta pesquisa de mestrado pretende demonstrar uma nova concepção de conhecimento e a interferência dos fatores emocionais no processo de ensino/aprendizagem; traça, como objetivo principal, apresentar a dinâmica proposta por Polanyi sobre os princípios envolvidos na síntese (objetiva + subjetiva) do conhecimento e os fatores emocionais (complexo de inferioridade e megalomania/teomania) que bloqueiam o aprendizado - sobretudo de línguas estrangeiras. Para cumprir o que se propõe, explicita a proposta de Michael Polanyi, que propõe a transcendência da dicotomia do objetivo/subjetivo, mostrando a importância de se trabalhar com os aspectos subjetivos no contexto educacional. Sua abordagem elucida que sabemos muito mais do que podemos relatar (We know more than we can tell) e sintetiza que todo conhecimento é pessoal e que não pode ser descrito, mas que combinado com o mundo explícito, gera genuínas paixões intelectuais. Foi possível verificar que a proposta de Polanyi fornece ferramentas para a compreensão dos impedimentos sobretudo emocionais da articulação do saber tácito com o explícito na incorporação de novos conhecimentos chamada por ele de Indwelling. Também foi possível elucidar algumas das motivações de comportamentos obstaculizantes, a partir da discussão do Complexo de Inferioridade (1977), de Alfred Adler, e da Teomania (1980), de Norberto Keppe. Finalmente verifica-se que muitas das razões, motivações e intenções de um indivíduo podem estar frequentemente fora do seu campo de visão consciente, podendo levá-lo a atitudes e ações inconscientizadas, as quais o prejudicam até mesmo na aprendizagem de línguas estrangeiras. Sendo essencial conhecer aquilo que impede o próprio conhecimento, torna-se possível a sustentação do discurso de emoção voltado para pensar as interações em sala de aula.

Palavras-chave: Conhecimento tácito. Ensino de línguas estrangeiras. Bloqueios emocionais na aprendizagem. Teomania. Inconscientização. 


\section{AVELINO, L.B. O conhecimento tácito e os impedimentos emocionais no processo de}

ensino/aprendizagem de línguas estrangeiras. 2018. 97 f. Dissertação (Mestrado em Educação). Faculdade de Educação, Universidade de São Paulo, São Paulo, 2018.

\section{Résumé}

La recherche de ce master a pour but de démontrer une nouvelle conception de la connaissance et l'interférence de facteurs émotionnels dans le processus d'enseignement/apprentissage; établie comme objectif principal, présenter la dynamique proposée par Polanyi sur les principes impliqués dans la synthèse (objective + subjective) de la connaissance et les facteurs émotionnels (complexe d'infériorité et mégalomanie/théomanie) qui bloquent l'apprentissage en particulier les langues étrangères. Pour répondre à ce qui est proposé, ce projet présente explicitement la proposition de Michael Polanyi, qui suggère transcender la dichotomie objectif/subjectif, en soulignant l'importance de travailler avec les aspects subjectifs du contexte éducatif. Son approche précise que nous en savons beaucoup plus que nous ne pouvons en dire (We know more than we can tell), et il synthétise que la connaissance est personnelle et ne peut pas être décrite, mais, combinée avec le monde explicite, génère de véritables passions intellectuelles. Il a été possible de vérifier que la proposition de Polanyi fournit des outils pour la compréhension des obstacles principalement émotionnels de l'articulation du savoir tacite avec l'explicite dans l'incorporation de nouvelles connaissances appelées par lui d'Indwelling. Il a également été possible d'élucider certaines motivations du comportement obstructif, à partir de la discussion du Complexe d'Infériorité d'Alfred Adler (1977) et de Théomanie de Norberto Keppe (1980). Finalement, c'est observé une grande partie des raisons, motivations et intentions d'un individu peut souvent être en dehors de son champ de vision conscient et peut le conduire à des attitudes et actions inconscientisées, pouvant lui nuire gravement, y compris au niveau d'apprentissage des langues étrangères. Étant essentiel de savoir ce qui empêche notre propre connaissance, il devient possible de maintenir le discours émotionnel visant à penser les interactions en classe.

Mots-clés: connaissances tacites. Enseignement des langues étrangères. Blocages émotionnels dans l'apprentissage. Théomanie. Inconscientisation. 


\section{LISTA DE FIGURAS}

- Figura 1 - Dinâmica do conhecimento tácito

- Figura 2 - Iceberg - objeto imerso em fraca e alta densidade 48

- Figura 3 - Processos Psicológicos Ligados a Problemas Acadêmicos e Tensão

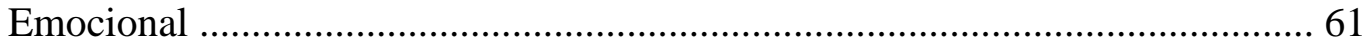




\section{LISTA DE QUADROS E TABELAS}

- Quadro 1 - Idades históricas

- Tabela 1 - Tabela de um quadro interpretativo 
INTRODUÇÃO ..............................................................................................................11

1 CONCEPÇÕES OBJETIVAS E SUBJETIVAS DO CONHECIMENTO ..................118

1.1 Princípios racioinais de René Descartes e o conhecimento objetivo de Karl Popper ........18

1.2 Giambattista Vico, sua visão histórica do homem e a importância da língua .................... 24

1.3 Blaise Pascal: "O coração tem razões que a própria razão desconhece”............................26

2 BUSCA DA SÍNTESE NA REPRESENTAÇÃO DE MICHAEL POLANYI................30

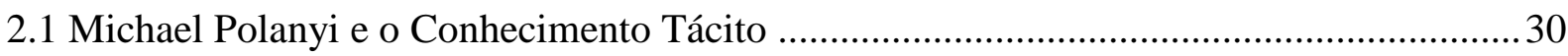

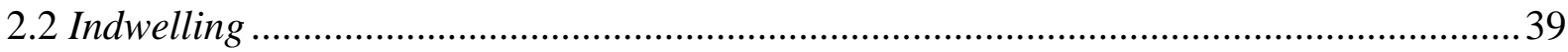

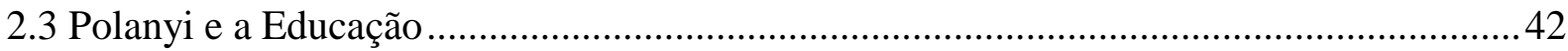

3 AS DIMENSÕES EMOCIONAIS E OS BLOQUEIOS NA APRENDIZAGEM DE LÍNGUAS ESTRANGEIRAS ........................................................................................554

3.1. Alfred Adler e o Complexo de Inferioridade e Norberto Keppe e a Teomania ................63

3.2 O Inconsciente Freudiano e a Inconscientização Keppeana..............................................73

3.3 Análises Pedagógicas e Reflexões sobre as Práticas Docentes no Ensino e Aprendizagem

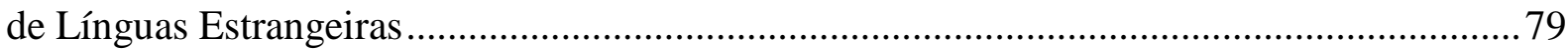

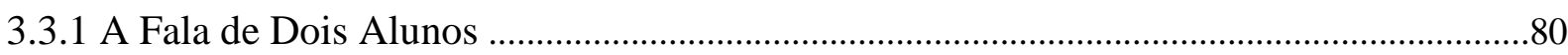

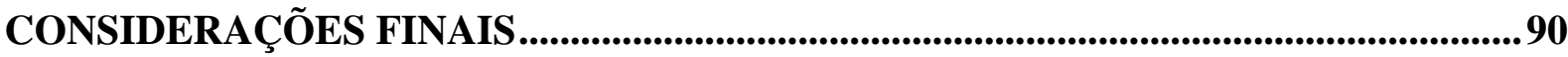

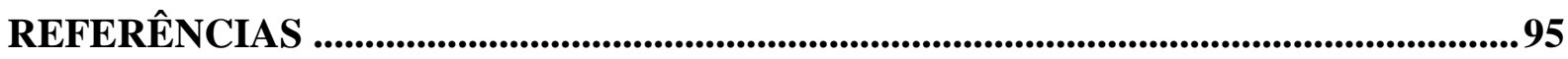




\section{INTRODUÇÃO}

Em mais de duas décadas de trabalho docente, posso afirmar que já observei "diferentes" práticas de ensino. Todavia, uso as aspas, pois no fundo, as praxes que tenho observado já não me parecem assim tão distintas entre si. É comum, por exemplo, encontrar ainda hoje discursos que defendem a objetividade e a racionalização nos processos educacionais, de modo a propagarem a ideia de que os alunos são unicamente sujeitos que aprendem e os professores são exclusivamente sujeitos que ensinam. Entretanto, o que minha experiência docente tem demonstrado é que a presença de aspectos subjetivos influencia as funções cognitivas positivas e negativas dos alunos.

Desde 1996 atuo como professora de inglês e francês em um Centro de Línguas de uma faculdade em São Paulo que utiliza um método terapêutico Psicolinguístico Trilógico que busca conscientizar os alunos dos bloqueios psicológicos que impedem a aprendizagem de línguas estrangeiras. Este trabalho me motivou a pesquisar as causas do aumento de problemas anímicos nos ambientes educacionais em geral.

Fatores emocionais, de grande carga subjetiva, alteram sobremaneira as dimensões do conhecimento para cada aluno, fazendo com que os estudantes se afastem ou se aproximem daquilo que estão aprendendo. $\mathrm{Na}$ área de ensino de línguas, esses bloqueios no momento da aprendizagem ficam ainda mais evidentes. Perceber, então, que o processo de ensino/aprendizagem é permeado por fatores subjetivos me causou uma série de questionamentos, entre eles:

a) Como reconhecer os bloqueios emocionais que impedem os alunos de desenvolverem suas habilidades linguísticas?

b) Como compreender o modo pelo qual o aluno, em todos os níveis de escolarização, resiste à aprendizagem de forma inconsciente, obstaculizando seu desempenho cognitivo?

Ao encontrar a abordagem de Michael Polanyi (1891 - 1976), a partir da sua teoria "Conhecimento Pessoal" (1958), entendi que não se tratava de uma escolha entre a objetividade e a subjetividade para a compreensão da realidade no âmbito educacional. Os estudos de Polanyi representam a síntese das duas escolhas (visão objetiva + visão subjetiva); o autor apresentam a ideia da existência de um conhecimento tácito ${ }^{1}$ em cada indivíduo que, na

\footnotetext{
${ }^{1}$ De forma resumida, podemos dizer que o termo, usado por Polanyi (1958), designa um conhecimento interior que pode ser captado ou criado por uma mente em relação a um pormenor subsidiário. Seria um conhecimento mais internalizado. Ao longo do trabalho, discutiremos mais essa ideia.
} 
combinação com o mundo exterior (explícito), gera uma forma de conhecimento genuíno, provocador de paixões intelectuais. Segundo essa teoria, o modo natural pelo qual conhecemos/reconhecemos a realidade é - subsidiário - de difícil explicitação em palavras ou articulação em teorias.

Para refletir sobre essa síntese entre o objetivo e o subjetivo, Michael Polanyi percebeu a necessidade de realizar uma revisão das principais vertentes da Filosofia da Ciência e do Conhecimento, por entender que, a partir da Revolução Científica do século XVIIII, as principais teorias passaram a ter como base um modelo de objetividade. Segundo o teórico, tal busca pelo racional tornou o homem uma máquina, sem contato com a realidade, o que fomentou todo tipo de sociedades totalitárias.

A abordagem proposta por tal autor me encantou pelo aspecto dinâmico do conhecer, de forma a manifestar uma renovação no estado das coisas e do mundo, a cada antecipação do conhecimento, feito pelo fator subsidiário e pela capacidade de readaptação a situações novas sem precedentes. Essa dinamização me parece enriquecer o processo de ensino/ aprendizagem, e se transformar em uma marca da personalidade inteligente (POLANYI, 2013), pelo dinamismo do saber subsidiário que cada um de nós possui.

A partir da mobilização dessa teoria passei a fundamentar a minha proposta de pesquisa de modo a responder às indagações que tinham surgido durante minha caminhada como professora. De modo que o objetivo principal deste trabalho de pesquisa passou a ser: demonstrar a dinâmica proposta por Polanyi, e os fatores emocionais envolvidos na síntese (objetiva + subjetiva), que bloqueiam o aprendizado, sobretudo de línguas estrangeiras e suas possíveis inconscientizações.

A partir do objetivo principal, outros objetivos específicos foram construídos, entre eles:

I) Demonstrar a preponderância da visão objetiva e racional nos espaços de ensino;

II) Debater os prejuízos ocasionados pela separação entre conhecimento e conhecedor;

III) Apresentar a epistemologia proposta por Michael Polanyi como possibilidade de uma síntese do objetivo/subjetivo;

IV) Compreender algumas das razões pelas quais alguns alunos bloqueiam suas possibilidades abstrativas e a explicitação de seus conhecimentos tácitos e de suas Indwellings (incorporações), com base no Complexo de Inferioridade, proposto por Alfred Adler (1977) e na t

V) Teomania (Megalomania) proposta por Norberto Keppe (1980) - que, segundo os autores citados, funcionam como elementos impeditivos de subjetividades e, portanto, são formadores de bloqueios; 
VI) Asseverar como muitos desses fatores inibidores estão fora do campo consciente do indivíduo, exigindo uma conduta de responsabilidade face às atitudes inconscientes. Dois exemplos de alunos de um curso de inglês de uma escola de línguas em São Paulo, capital foram usados para ilustrar a problemática tratada.

Logo, o texto final deste trabalho está estruturado da seguinte maneira:

Primeiro Capítulo: Nele se busca compreender como se construiu a base objetivista do contexto de ensino/aprendizagem. O principal conceito estudado é o da "Representação", tendo como base as ideias de René Descartes (1596 - 1650) (2002). A partir de tal conceito, Descartes criou o seu método através da dúvida e da busca pelo racional. Concluímos, então, que o método cartesiano serve como base para a maioria das teorias na área de ensino e para a ciência de um modo geral.

Em seguida analisamos, as ideias presentes no livro o Conhecimento Objetivo (1975), de Karl Popper (1902-1994), em sintonia com o pensamento de Descartes, pelas quais se afirmam que "é verificando a falseabilidade de nossas suposições que de fato entramos em contato com a "realidade"” (1975, p. 77). De certo modo, Popper elucida, assim, os prejuízos da aplicação de uma epistemologia sem um sujeito conhecedor. Fazendo-se necessário entender que no processo de conhecimento há outras considerações filosóficas e motivações emocionais que não são mensuráveis através dos padrões racionais cartesianos.

O ideal de objetividade científica, representado também na figura de Karl Popper, acarreta a necessidade de só se aceitar o que pode ser comprovado, logo, considerações de ordem moral ou afetiva devem ser tratadas separadamente como dimensões isoladas do funcionamento psíquico humano. Essa visão não afetou apenas o estudo das emoções, mas a psicologia e a educação de um modo geral (ARANTES, 2003). Além dessas consequências da visão cartesiana dicotômica da realidade, discutimos também, o impacto negativo do privilégio de uso estrito da objetividade na construção do conhecimento e da identidade do sujeito.

Para desenvolver análises sobre o processo de construção do conhecimento que considerassem elementos subjetivos em sua composição, ainda no capítulo em questão, elencamos alguns filósofos consagrados (abaixo), em busca de aberturas possíveis para o entendimento das múltiplas dimensões afetivo-emocionais envolvidas na compreensão do conhecimento, tais aberturas se contrapõem frontalmente ao racionalismo cartesiano.

Apresento, então, um resumo das ideias das principais teorias dos filósofos que compõem a discussão:

- Giambattista Vico (1668 - 1744) (1974) com sua visão histórica do homem como única possibilidade de compreensão do seu desenvolvimento, fazendo uso 
da filologia para ressaltar a importância da imaginação do homem através da língua.

- Pascal (1623 - 1662) (1973) com sua máxima "o coração tem razões que a própria razão desconhece" (1973, p. 111) nos oferecendo entrepostos demonstrativos de percepções da realidade a partir dos sentimentos.

As reflexões propostas por esses dois autores serão importantes para se compreender que o embate de duas formas dicotômicas de entender a realidade (objetiva e subjetiva) nos leva cada vez mais à ideia de síntese na composição do entendimento do conhecimento. E é nessa busca que nos dedicamos, no Segundo Capítulo, à nova epistemologia de Michael Polanyi (1958).

Segundo Capítulo: Concentra-se na discussão sobre a teoria de Polanyi (1986), que andou na contracorrente dos estudos da época e realizou uma longa e exaustiva investigação sobre como o ser humano chega ao conhecimento - o "conhecer"- em uma abordagem totalmente nova, no seu livro Personal Knowledge (1958) (Conhecimento Pessoal) (1986). Nessa obra, o autor abandonou a noção de que o conhecimento era pura objetividade (ideia impregnada em toda a filosofia ocidental), de forma a reconsiderar como se constrói conhecimento a partir do fato de que podemos saber mais do que podemos dizer, o que caracteriza um conhecimento pessoal "tácito" submerso. Estabeleceu a ideia "We know more than we can tell" (Nós sabemos mais do que podemos dizer) (1986, p. 51), visão que estabelece um contraponto ao conhecimento explícito (o par consciente/inconsciente do processo). Esse procedimento parece bastante óbvio, mas não é fácil de explicar. Comunicamos, expressamos nossos sentimentos, raciocinamos, amamos, odiamos muito mais do que conseguimos revelar (ARANTES, 2003, p. 230).

$\mathrm{O}$ autor exemplifica, afirmando que quando conhecemos o rosto de uma pessoa, podemos reconhecê-lo entre mil outros rostos ou até entre um milhão. No entanto, geralmente não conseguimos explicar como reconhecemos esse rosto conhecido. Portanto, a maior parte desse conhecimento não podemos expressar em palavras. Tal concepção causou muito impacto sobre a visão positivista do conhecimento científico, já que é a gênese de uma nova compreensão da realidade, que se desconecta do conhecimento somente objetivo. Ou seja, não é comprando uma excelente enciclopédia que estou comprando conhecimentos. O conhecimento não se objetiva fora das pessoas. Ele é pessoal.

Com os trabalhos de Polanyi (1958), foi delineada uma nova epistemologia que inclui o conhecimento tácito e o explícito em constante interação. É a dimensão tácita do conhecimento humano, enquanto rede complexa de indicações, que utilizamos para interpretar e produzir 
conhecimento explícito; esse não é, assim, obtenível sem que o primeiro se constitua como contexto de referência dentro do qual seja possível a sua compreensão. Assim, o indivíduo oscila entre o saber tácito e explícito a cada segundo da sua vida, uma vez que é exclusivamente humana a capacidade de fundir o novo e o velho conhecimento.

Essa mescla de produção de conhecimento norteia o dia a dia dos indivíduos, contendo uma aprendizagem tão pessoal e intrínseca que as suas regras podem ser impossíveis de separar da forma como cada indivíduo age. Por essa razão, sendo altamente experiencial, pessoal e específico do contexto, o conhecimento tácito é, consequentemente, mais difícil de formalizar, comunicar e partilhar.

Terceiro Capítulo: Tem o objetivo de investigar algumas possibilidades de entendimento das razões pelas quais alguns alunos bloqueiam suas possibilidades abstrativas e a explicitação de seus conhecimentos tácitos e de suas Indwellings. Investigaremos, portanto, possíveis formas ou atitudes que podem ser consideradas austeras e imponentes de alguns alunos e professores, as quais costumam gerar grandes conflitos nas escolas. Assim, optamos pela seleção do Complexo de Inferioridade de Alfred Adler (1870 - 1937) (1977), na sua teoria da Psicologia Individual, que defende a ideia de que as crianças se desenvolvem do modo que melhor lhes permita compensar suas fraquezas. Ao mesmo tempo em que desejam o reconhecimento dos outros, possuem um senso de inferioridade; é a tentativa da psiquê de banir esse sentimento de inferioridade vai frequentemente moldando a vida de cada criança, de tal modo que ela tentará compensar isso de maneiras extremas, algumas vezes. Se um complexo pode fazer alguém mais tímido ou introvertido, ele pode, igualmente, produzir a necessidade de compensar isso com um desempenho excepcional. É a chamada dinâmica patológica expressa à custa de outras pessoas e da sociedade em geral. Adler analisou o caso do imperador francês Napoleão Bonaparte (1769 - 1815), um homem de estatura pequena, que causou grande impacto no mundo, como um clássico complexo de inferioridade em ação.

Outro conceito de grande importância é o do psicanalista e filósofo Norberto Keppe, que trabalhou com o professor Viktor E. Frankl² (1905 - 1997), e afirmou que o ser humano contemporâneo sofre de uma enorme obsessão com o antropocentrismo e com a teomania - o desejo de ser um Deus. A pessoa que fantasia muito revela sobremaneira sua teomania, usando de um linguajar teórico que poucos conseguem acompanhar, uma vez que pertence ao seu mundo exclusivo, desconectado da realidade. As pessoas, nesse caso, têm grande dificuldade de estabelecer diálogo com indivíduos com essas características.

\footnotetext{
${ }^{2}$ Fundador vienense da Logoterapia, que explora o sentido existencial do indivíduo.
} 
Se o grau de teomania for muito elevado, a censura será também muito forte e a pessoa não terá tolerância para admitir os seus erros, pois ela gostaria de se ver como um "anjo" ou um “Deus", de preferência, que não comete enganos, nem tem más intenções, maus pensamentos e atos. Keppe (1980) acredita que a censura é formada pela teomania do próprio indivíduo, mas é reforçada principalmente pelo ambiente, através de pais, professores e da sociedade em geral, que censuram e não toleram as falhas alheias.

No contexto do ensino, nós professores, repetidas vezes, deparamo-nos com alunos austeros e arrogantes que se colocam acima do professor e da aprendizagem, impedindo-se de aprender.

Alfred Adler (1977) e Norberto Keppe (2001) são autores com teorias importantes que ajudam a compreender quais são as dificuldades emocionais manifestas em sala de aula. Uma das principais bases da problemática carrega fortes fatores inconscientizados de arrogância e teomania; algumas serão amplamente exemplificadas para compreensão do fenômeno. A descoberta dos conteúdos "subterrâneos" da vida psíquica mostra como pequenos ou, às vezes, poderosos acontecimentos intrapsíquicos estão ativos dentro de nós, sem a nossa mínima percepção.

Ainda no Terceiro Capítulo, apresentamos um esboço a respeito de como ações e motivações de professores e alunos podem estar inconscientizadas (fora do campo de visão consciente do indivíduo). Assim, o objetivo desse capítulo será aproximar nossa visão de um tipo de conhecimento inconscientizado e não racional que rege nossas vidas. Quando o indivíduo tem mais consciência, ele assume maior responsabilidade por suas subjetividades, devido a ter menos material inconscientizado. Quando ele tem menos consciência, ele tem maiores dificuldades para entender as suas próprias subjetividades e as dos outros. O objetivo é delinear a constituição do que Keppe chama de inconscientização ${ }^{3}$ (PACHECO, 2001) e que vai caracterizar a concepção de sujeito e linguagem insensíveis ao pensamento racionalista/positivista predominante.

Completando o Terceiro Capítulo, delineamos o contexto de sustentação do discurso de emoção, voltado para as formas e para a complexidade das interações em sala de aula.

Considerações Finais: Nas considerações desta investigação é feita uma tentativa de síntese, apontando exemplos práticos de sala de aula que consideram a análise dos aspectos subjetivos/emocionais inconscientizados no processo de ensino-aprendizagem de línguas

\footnotetext{
${ }^{3}$ Neologismo criado por N. Keppe (1980) que se refere: atitude de esconder, reprimir ou negar a consciência que temos.
} 
estrangeiras. Assim, mostrando a possível necessidade da consideração das dimensões analíticas na base do entendimento da problemática emocional, ou seja, da conscientização de fatores inconscientizados, propostos por Freud (1856 - (2018) e Keppe (1980).

Debatemos, portanto, as buscas necessárias para que os professores considerem a dinâmica proposta por Polanyi, e os fatores emocionais envolvidos na síntese (objetiva + subjetiva), que bloqueiam o aprendizado, sobretudo de línguas estrangeiras e suas possíveis inconscientizações. 


\section{CONCEPÇÕES OBJETIVAS E SUBJETIVAS DO CONHECIMENTO}

Duas principais concepções baseiam os discursos científicos e, consequentemente, nossa forma de ver o mundo: as ideias de objetividade e de subjetividade. Usamos tais palavras cotidianamente como se soubéssemos o que de fato elas significam, como se fossem óbvias, principalmente no contexto de ensino e na relação de ensino/aprendizagem. O que se fundamentou é que: o ideal objetivo está ligado à realidade mais concreta, de conteúdo lógico e racional, geralmente associado diretamente com a ciência (verdade como correspondência de fatos); já o ideal subjetivo está ligado à realidade mais sutil, tendendo mais ao afetivo-espiritual de cada um, na noção de subjetivismo maior, superior. Em se tratando do entendimento dessas concepções do conhecimento, "o embate objetivo/subjetivo realiza-se com muito vigor, constituindo uma questão aberta, ainda que a perspectiva da objetividade seja amplamente hegemônica" (MACHADO, 2015, p. 29-30).

Para se compreender o referencial básico do posicionamento da dimensão objetiva temos que nos voltar às ideias de René Descartes (1596 - 1650), que inaugurou a idade moderna com seu racionalismo, negando as paixões. Outra representação importante é a de Karl Popper (1902-1994) em seu livro Conhecimento Objetivo (1975), no qual ele nega qualquer ideia que leve em conta a subjetividade, construindo seus argumentos a partir de ideais de precisão e justiça absoluta através de conceitos e categorias. Abordaremos, portanto, o tema da objetividade e, em seguida, examinaremos algumas visões que se opuseram frontalmente a essa visão objetiva hegemônica de René Descartes e Karl Popper; tratamos das visões de Giambattista Vico (1668 - 1744) (1974) e Blaise Pascal (1623 - 1662) (1973).

\subsection{Princípios racionais de René Descartes e o conhecimento objetivo de Karl Popper}

Na Idade Média, devido à força e ao poderio dos preceitos religiosos, o conhecimento só era aceito se tivesse uma relação estreita com a razão teológica. Para se libertar dessa influência teocrática, de caráter inquisidor e opressor, o homem medieval agarrou-se ao novo conhecimento de mundo lançado, por exemplo, pelo pensador René Descartes, que estabeleceu as bases de uma nova ciência, através do princípio epistemológico estabelecido pela razão. Com o Método Dedutivo, Descartes colocou como ponto de partida o conhecimento racional das coisas e estabeleceu a dúvida metódica como critério de validação científica.

Devido ao fato de que tanto os sentidos como a razão podem nos enganar, Descartes valoriza especialmente o conhecimento intelectual, racional, desvalorizando o campo do 
sentimento. Não desconhecia ou ignorava as paixões, mas afirmava que o sábio deve combatêlas, destruí-las e até aniquilá-las (DESCARTES, 2012). Como mencionado no livro As Paixões da Alma (Idem):

Entretanto, o que os antigos ensinaram a respeito delas é tão pouco e, na maior parte, tão pouco crível, que não posso alimentar nenhuma esperança de me aproximar da verdade, a não ser distanciando-me dos caminhos que eles trilharam (p. 31).

E termina o livro dizendo:

De resto, a alma pode ter seus prazeres à parte. Para aqueles, porém, que lhe são comuns com o corpo, dependem inteiramente das paixões, de modo que os homens que elas podem mais emocionar são capazes de degustar mais doçura nesta vida. É verdade que podem também encontrar nela mais amargura, quando não souberem empregá-las bem e quando a sorte lhes é contrária. A sabedoria, porém, é particularmente útil neste ponto, porquanto ensina a tornar-se de tal modo senhor delas e a manejá-las com tal destreza, que os males que causam são perfeitamente suportáveis e que até mesmo alguma alegria se pode tirar de todos eles (idem, p. 152).

Nesse último trecho, o autor mostra a necessidade de tomar distância das paixões para aprender a controlá-las e assim chegar à verdade. Isto é, já mostra uma aversão em relação à consideração das emoções como parte integrante do indivíduo, como se as emoções fossem dispositivos que promovessem a desorganização das ideias. A partir de tal conceito, o autor submete à natureza a unidade da razão, já que a consciência da existência de um sujeito receptor de conhecimento se faz inquestionável. Cria-se, com Descartes, assim uma separação entre razão e emoção, princípio fundamental no pensamento humano com a afirmação de um sujeito epistêmico, elemento primordial na constituição da Ciência Moderna.

Desse modo, o método cartesiano defendia que a razão era o único meio pelo qual se descobrem algumas verdades universais. Também defendia a matemática e a geometria como ciências seguras, pois fornece grande "segurança" ao indivíduo, porque dá a impressão de responder a todas as questões que levanta. Vamos dizer que este campo encaixa todas as formulações dentro de suas fronteiras objetivas e dá a ideia de superioridade, colocando a origem da existência não no pensamento do Criador, mas no da criatura.

Descartes exclui o incerto e o duvidoso, separa a razão e os sentimentos, recusando a imaginação como parte constituinte do processo do conhecimento, pois considera o ato imaginativo como a fonte das ilusões e inverdades. Consequentemente, passa a difundir a ideia 
de que o conhecimento do mundo humano (subjetivo) não tem espaço no âmbito científico (CUNHA, 2013).

As principais abordagens filosóficas, pedagógicas e psicológicas, que pretendiam debater o processo de aquisição de conhecimento, estabeleceram as suas bases fundantes no pensamento cartesiano, colocando de lado qualquer fator de subjetivação. O descrédito para as ideias que tentam articular fatores emocionais no processo educativo ainda é muito grande pelo fato da tradição teórico-filosófica ocidental compreender as emoções como um veneno para a alma (ARANTES, 2003, p. 38). Ou seja, falar de subjetivismo geralmente envolve uma depreciação, pela imprecisão inerente a questões subjetivas; afinal, fala-se pouco sobre quais seriam os aspectos subjetivos no processo de ensino/aprendizagem. Por isso, questionamos: Como coadunar o elogio da construção da identidade pessoal, plena de elementos emocionais e afetivos, com uma frequentemente explícita depreciação da subjetividade? (ARANTES, 2003).

Acredita-se, pela perspectiva da objetividade, que se deve analisar um objeto tirando dele as informações mais objetivas possíveis, as que são mais comprováveis. No entanto, não se pode esquecer que o ato de tentar enxergar o óbvio já um exercício de uso da sensibilidade. Se observarmos a História, notamos que tudo vai depender do ponto de vista; por exemplo, muitas guerras sempre foram contadas pelos vencedores; logo, não podemos dizer que temos uma visão objetiva da História, já que se contam os fatos a partir de um único ponto de vista.

Precisamos, portanto, reexaminar a distinção entre sujeito e objeto, que aprofunda a diferença entre o humano e não-humano, visto que a desumanização do objeto foi crucial para consolidar uma concepção do conhecimento instrumental e regulatória, cuja forma de saber era a conquista do caos pela ordem. Um conhecimento objetivo e rigoroso, baseado nos fatos, não aceita a interferência de valores humanos ou religiosos e, portanto, nesse momento, cria-se a distinção entre sujeito e objeto articulada metodologicamente pela distância.

Os pressupostos metafísicos, os sistemas de crenças, os juízos de valor não estão antes nem depois da explicação científica da natureza ou da sociedade, eles são parte integrante dessa mesma explicação. A ciência moderna não é a única explicação possível da realidade e não há sequer qualquer razão científica para a considerar melhor que as explicações alternativas da metafísica, da astrologia, da religião, da arte ou da poesia (SOUZA SANTOS, 2011). O racionalismo/positivismo, que privilegiamos hoje, sob a forma de conhecimento, assenta-se na previsão e no controle dos fenômenos, o que nada tem de científico. É um juízo de valor.

Muitas metodologias exigem naturalmente uma intimidade com o objeto, ou seja, um trabalho de observação paciente, de diálogos, de convívio etc. Para isso, é necessária uma outra 
forma de conhecimento, mais compreensivo, que nos una pessoalmente ao que estudamos. As incertezas do conhecimento (vistas como limitações técnicas pela modernidade), podem, quiçá, se transformar na chave de melhor entendimento do mundo (SOUZA SANTOS, 2011).

$\mathrm{O}$ que se pode afirmar é que a proposta racionalista investiu em um método de pensamento para chegar ao conhecimento a partir de ideias claras e objetivas, que não podem se emaranhar ao complexo mundo da subjetividade. Normalmente, optamos por essa ideia de objetividade palpável, já que ela se apresenta como um modo seguro de compreensão do mundo a nossa volta, pois é guiada por dados mensuráveis e cientificamente passíveis de prova. O livro Conhecimento Objetivo de Karl Popper (1975), por exemplo, expressa a necessidade de uma atitude extremamente crítica a qualquer fenômeno, de modo a negar qualquer consideração séria da subjetividade e exigir a testabilidade dos fatos para a verificação da veracidade deles. A teoria da falseabilidade proposta pelo autor exige que a verificação do acerto científico só possa ser feita através da percepção do erro das teorias, tirando o acerto da falsidade.

A teoria de Popper (1975) exemplifica bem uma tendência natural de rejeitar a utilização de qualquer método que não garanta a objetividade do conhecimento objetivo (logos). Para o autor (1975), apenas pela tentativa de falseabilidade de um experimento é que se pode chegar a uma verdade científica que pode ser refutada. O que interessa para Popper é apenas o que vem do experimento para frente. O que vem do sujeito não interessa, inclusive nesse sentido ridiculariza a psicologia da criação. Segundo a ideia proposta, ao se criar algo, só se pode apurar se a criação é falsa, numa única constatação possível para se chegar à realidade (POPPER, 1980). O referido teórico acreditava que essa seria a explicitação máxima de uma teoria do conhecimento subjetivo. Portanto, não há verdades, apenas comprovações momentâneas até que se prove a sua falha. Nesse sentido, toda a subjetividade, inclusive a artística, não é levada em consideração.

No trecho abaixo de seu livro Em Busca de um Mundo Melhor (2006), Popper ilustra bem o assunto, expressando de maneira irônica o desejo firme de procurar o problema para se chegar à verificação da verdade científica:

Penso que só há um caminho para a ciência ou para a filosofia: encontrar um problema, ver a sua beleza e apaixonar-se por ele; casar e viver feliz com ele até que a morte vos separe - a não ser que encontrem um outro problema ainda mais fascinante, ou, evidentemente, a não ser que obtenham uma solução. Mas, mesmo que obtenham uma solução, poderão então descobrir, para vosso deleite, a existência de toda uma família de problemas-filhos, encantadores ainda que talvez difíceis, para cujo bem-estar poderão trabalhar, com um sentido, até ao fim dos vossos dias. (POPPER, 2006, p. 2) 
Segundo o autor, somente na busca do erro é que podemos ter a certeza do verídico. Tal concepção, como discutido, despreza completamente todo o universo subjetivo, abstrato e criativo, como se fosse, fora da realidade. O cenário científico ocidental está baseado em tal visão, a expectativa dominante é, portanto, a objetividade do conhecimento (MACHADO, 2015).

Para entendermos melhor a influência da perspectiva de Popper, Machado (2003) mostra a maneira como o teórico citado fundou uma epistemologia - sem um sujeito conhecedor- baseada em três mundos:

- o mundo 1 seria o mundo físico, formado pelos objetos cuja existência independe de qualquer sujeito conhecedor; - o mundo 2 teria como conteúdo nossas percepções sensoriais dos objetos do mundo 1, nossas experiências conscientes relacionadas com tais objetos; - o mundo 3 seria formado pelas teorias, pelos conteúdos lógicos de livros, de bibliotecas, de arquivos de computadores, de elaborações teóricas pela experiência nos mundos 1 e 2 . Para Popper, o conhecimento baseado nas percepções sensoriais, associado ao mundo 2, é subjetivo, e nem mesmo merece ser chamado conhecimento; todo ele seria absolutamente dependente do mundo 3 , uma vez que toda observação é inevitavelmente guiada por uma teoria. Não obstante tal fato, Popper argumenta quanto à relativa independência do mundo 3 , pretendendo que teorias são formuladas, ou descobertas em sentido platônico, no universo das ideias, de modo análogo aos que foram utilizados nas descobertas geográficas nos mundos 1 e 2, na época das grandes navegações marítimas: assim como as terras americanas preexistiam relativamente às concepções sobre elas, as teorias também preexistiriam, esperando pelo momento/contexto adequado para aflorar nas mentes dos cientistas. (p. 36-37).

Segundo o pensamento de Popper, então, o verdadeiro conhecimento somente pode existir fora das mentes das pessoas: sendo considerado o conhecimento objetivo, ou conhecimento no sentido objetivo, que consiste no conteúdo lógico de nossas teorias, conjecturas, suposições. Desse modo, o conhecimento objetivo desconsidera o processo para se chegar ao conhecimento, mas privilegia o mecanismo de teste para colocá-la a prova. Se a teoria se mostrar coerente depois da checagem é considerada científica. Popper procura aplicar suas ideias também nas ciências sociais em A Sociedade Aberta e Seus Inimigos e em A Miséria do Historicismo. De acordo com essa perspectiva, a crítica, portanto, é o melhor método de aprimoramento tanto para a ciência como para a política.

Assim, podemos concluir que a partir da soberania da objetividade se consegue somente provar que algo não é, mas não o que é. Nesse caso, se o objetivo da educação é o conhecimento, baseado nas teorias de perspectiva unicamente objetiva, são descartados os processos de confiança, de construção de estabilidade e autoestima no processo de ensino/aprendizagem, pois esses valores estariam ligados a aspectos subjetivos. Popper, por exemplo, desconsidera o 
processo intuitivo, imaginativo e criativo como forma de conhecimento. A arte, a poesia e a religião, fazendo parte da seara subjetiva, não deveriam integrar o escopo humano de aprendizagem, para ele.

Talvez, na atualidade tenhamos melhores condições de entender que não podemos prever cientificamente as consequências de todos os fenômenos; e que todo esse positivismo possa ter sido também fonte de manipulação, como explica Souza Santos em seu livro A Crítica da Razão Indolente (2011).

A ciência moderna consagrou o homem enquanto sujeito epistêmico, mas expulsou-o enquanto sujeito empírico. No mais eloquente tratado sobre subjetividade produzido pela modernidade ocidental nada se dirá sobre nós próprios enquanto seres humanos vivos, empíricos e concretos. Um conhecimento objetivo e rigoroso não pode tolerar a interferência de particularidades humanas e de percepções axiológicas. Foi nesta base que se construiu a distinção dicotômica sujeito/objeto. Sabe-se hoje que as condições do conhecimento científico são mais ou menos arbitrárias, assentando em convenções que, entre muitas outras condições possíveis, selecionam as que garantem o desenrolar eficiente das rotinas de investigação. A ciência moderna existe num equilíbrio delicado entre a relativa ignorância do objeto do conhecimento e a relativa ignorância das condições do conhecimento que pode ser obtido sobre ele. A separação ente sujeito e objeto do conhecimento é, assim, feita de cumplicidades não reconhecidas. Isso explica porque é que, nas Ciências Sociais, a distinção epistemológica entre sujeito e objeto teve de se articular metodologicamente com a distâncias empírica entre sujeito e objeto (pp. 81-82).

Não podemos considerar que a realidade existe apenas para responder nossas perguntas e para ser submetida a categorias gerais; ou seja, não podemos acreditar que o objeto está a nossa disposição, à espera de que andemos "friamente" ao seu encontro. Segundo Souza Santos (2011), devemos considerar que - no momento atual da Pós-modernidade - a realidade se revela quando o ser humano se deixa chegar perto das coisas de maneira despida de previsibilidade e predição (que é o oposto dos mecanismos de controle do conhecimento racionalista).

Pode-se dizer que toda a epistemologia de Popper (1975), com sua visão de suspeição da realidade, falhou ao desconsiderar os aspectos subjetivos e até irracionais do ser humano, impedindo assim de se construir um conhecimento mais aprofundado da relação sujeito e conhecimento. De certo modo, a perspectiva objetiva da realidade é a que julgou sempre a psicanálise como "não científica”, já que o saber psicanalítico analisa os efeitos inconscientes. Deste modo, pode-se afirmar que tanto a visão de Descartes quanto a de Popper desprivilegia o que cada pessoa tem de mais autêntico: carisma, intuição, criatividade, emoção, etc. 
Perguntamos, então: Não seria essa a razão de tanto descalabros individuais e sociais, guerras, competições e desavenças, comprometendo inclusive a dimensão epistêmica do sujeito e do conhecimento?

No próximo item, na tentativa de encontrar uma visão mais sintética da análise do par objetivo/subjetivo em relação à apreensão do conhecimento, buscamos na representação de Giambattista Vico (1974) um respaldo histórico sobre as subjetividades.

\subsection{Giambattista Vico, sua visão histórica do homem e a importância da língua}

No século XVIII, na expansão da chamada Revolução Científica em diversas áreas do conhecimento, nascia também uma nova cultura, cujo núcleo era a ciência mecanicista, centro de uma nova racionalidade.

No entanto, nem todos os filósofos da época entraram nesse frenesi racional. Alguns autores contemporâneos de Descartes buscaram a compreensão da estrutura do conhecimento humano a partir de outros substratos. O filósofo Giambattista Vico (1668-1744), por exemplo, que estudou direito, filosofia e geometria, teve contato direto com as ideias de Descartes, criticou-o e propôs outro pressuposto filosófico para a compreensão da realidade.

Para Vico, segundo Souza (2007), o método geométrico cartesiano não nos garantiria a verdade dos nossos conhecimentos sobre as coisas humanas. Logo, ele considerava que Descartes errara ao acreditar que, por meio da matemática, uma criação humana, poder-se-ia entender o restante do universo, o qual segundo Vico é uma criação divina. A razão é a consciência do ser, mas não esgota o conhecimento que temos dele. O pensar não é suficiente para nos dar o conhecimento da nossa existência e tampouco nos garante o conhecimento total de quem realmente somos (SOUZA, 2007).

Vico (1974) elegeu a História como campo do conhecimento humano, substrato escolhido para aplicar seu método. Essa escolha, segundo o autor, derivou do fato de ser a História o produto da vontade do homem e por ser a "rainha de todos os estudos dedicados à realidade e ao conhecimento do que existe no mundo" (1982, p. 40). Vico, então, estabeleceu três idades históricas para o mundo: 
Quadro 1 - Idades históricas

Fonte: Vico (1974 apud SOUZA, 2007)

Vinculando cada uma dessas idades com uma determinada língua, o filósofo quis demonstrar "as modificações da mente humana". Na História, o relato dos feitos dos homens no espaço e no tempo, é produção da mente humana e, portanto, passível de ser apreendido e entendido; a linguagem tem grande importância nesse processo, acompanhando o desenvolvimento histórico do homem. Assim, Vico elegeu os estudos filológicos como de grande significado para a compreensão do desenvolvimento do ser humano. Considerando tais premissas, podemos entender a importância dos estudos históricos em detrimento dos estudos sobre a natureza (SOUZA, 2007).

A certeza viquiana reside, portanto, no fato de que a história é obra dos homens, e por conseguinte, a natureza humana pode ser vasculhada através da mente humana desde os seus primórdios; logo a Providência Divina desempenha um papel indubitável nesse processo, e nós, um papel de coadjuvantes. O homem conhece a História, pode definir a parte e o todo, pode imaginar as suas formas e pode figurá-las internamente, intuindo os seus primórdios. A História, como lugar em que a ciência e a consciência radicalmente se entrelaçam, supera o programa cartesiano, pois unifica o verum e ofactum e o certum (VICO, 1974, p. 15-16). O autor leva em consideração os aspectos de subjetividades envolvidos no processo histórico e, por isso, as bases do conhecimento repousariam em aspectos históricos e filológicos e não na certeza cartesiana.

Para Vico, a linguagem tem papel fundamental, pois os termos empregados pelo homem, em sua grande maioria, incluindo os teóricos e os abstratos, estão profundamente enraizados nas remotas formas de vida e de experiência. Assim, estudando-se etimologicamente a derivação das palavras, iluminam-se não só as condições ambientais de gerações anteriores, mas também os efeitos mais característicos dessas condições, transmitindo-nos suas origens e evoluções; o discurso e o pensamento ligam-se intimamente. (1988, p. 102). Desse modo, Vico acredita que a ciência não pode ter como linguagem unicamente a matemática, antes deve privilegiar uma linguagem mais bem elaborada. Souza (2007) expande essa ideia no pensamento de Vico, com o seu conceito de linguagem poética quando afirma: 
Que espécies de palavras têm sido utilizadas pelos seres humanos para expressar suas relações com o mundo, com eles entre si, e com os seus próprios passados? Vico fala do que ele chama de matriz poética da mente, ou seja, da linguagem poética da lei poética, moral poética. Lógica poética e assim por diante. Por poético ele quer dizer o que, de acordo com os alemães, nós tendemos a atribuir ao povo ou à gente, isto é, os modos de expressão usados pela massa do povo, ainda não sofisticados, dos primeiros anos da raça humana, e não pelas crianças daquela época antiga - fossem eles homens de letras, sábios ou peritos e com isso chegar ao conhecimento da vida espiritual desses povos, das fábulas, dos poetas, da vida da aurora civilização (BERLIM, 1976 apud SOUZA, 2007).

Nesse sentido, de acordo com o referido autor, Vico traz uma compreensão da significação humana muito mais profunda do que o "ergo sum" de Descartes, já que se propôs lidar com o conhecimento do substrato humano de maneira expressivamente mais rica, fornecendo-nos elementos vivos para consideração e compreensão das dimensões de expressões subjetivas de nossos alunos. A linguagem não pode ser a matemática, como exigida pelo racionalismo, mas estaria muito mais ligada a uma língua bem elaborado e à poesia.

Para Vico, a língua inicial era da interjeição: do sentimento e das emoções, revelando um substrato subjetivo; a partir dela veio a poesia (só depois de muito tempo veio a prosa). A visão do pensador sobre as interjeições, os sentimentos, a linguagem poética e as emoções nos ensina a darmos atenção aos elementos extrarracionais do conhecimento, de modo a apontar uma nova forma de linguagem para a percepção da realidade. De certo modo, passa-se a considerar que a linguagem não é literal, mas simbólica e se ocupa não dos valores neutros do mundo observável, mas da interpretação da dimensão transcendental da experiência humana.

Apesar do pensador ter nascido 18 anos depois da morte de Descartes, sua visão de mundo não conseguiu se contrapor ao racionalismo cartesiano, tão inflamado, da época (e que dura até hoje). Todavia, verificamos que a percepção de Blaise Pascal, uma personalidade importante, corrobora a ideia de Vico.

\subsection{Blaise Pascal: "O coração tem razões que a própria razão desconhece"}

Outra perspectiva nascida na época em que predominava o racionalismo de Descartes, foi o pensamento de Blaise Pascal (1973), que exaltava as seguintes premissas: “O coração tem razões que a razão desconhece" (1973, p. 111) e "Entro em pânico todas as vezes que eu vejo a cegueira e a miséria do homem, sem luz, abandonado a si mesmo, perdido nesse canto do universo, sem saber quem aqui o colocou, o que vai fazer e o que acontecerá quando morrer" 
(1973, p. 109). Tais ideias nos trazem outra forma de conhecimento que não está só baseado na lógica matemática, mas também está considerando o sentimento como parte integrante da vida humana.

A razão não é autossuficiente, a si mesma, ela tem limites; Pascal reconhece essas limitações e estabelece que a ética, a vida social e a religião são o que definem o mundo humano real; tal realidade, em grande parte, foge das possibilidades do racional. Portanto, a razão, também demonstra ser limitada quando busca definir as noções fundamentais de uma área do conhecimento, pois não consegue definir os princípios últimos da própria racionalidade que defende.

Pascal acreditava que uma das prioridades do nosso pensamento é pensar a nós próprios e não somente as coisas exteriores a nós. Ou seja, a tarefa principal do homem é conhecer a si mesmo e, para cumprir esse empreendimento, a razão não nos pode ajudar muito, pois é fraca, desnecessária e imprecisa, caindo constantemente na fantasia, no sentimentalismo e no hábito. Para conhecermo-nos o melhor caminho é o do coração.

No trecho abaixo, conseguimos compreender, pela ótica de Pascal (1974), a diferença entre um espírito de geometria (razão) e um espírito de finura (sentimento):

(...) estando acostumados aos princípios nítidos e grosseiros da geometria e a só raciocinar depois de terem visto bem e bem manejado os seus princípios, perdem-se nas coisas da finura, onde os princípios não se deixam manejar de igual modo. São apenas entrevistos; mais pressentidos do que vistos; é preciso um esforço infinito para torná-los sensíveis a quem não os sente por si próprios: são coisas de tal maneira delicadas e tão numerosas que é necessário um sentido muito delicado e muito preciso para senti-las, e para julgar retamente e justamente de conformidade com esse sentimento, sem poder o mais das vezes demonstrá-las em ordem, como na geometria, porque não lhes possuímos do mesmo modo os princípios, e tenta-lo seria um não acabar mais. É preciso, num instante, ver a coisa num só golpe de vista, e não pela marcha do raciocínio, ao menos até certo grau. E, assim, é raro que os geômetras, porque os geômetras querem tratar geometricamente essas coisas sutis e tornam-se ridículos, procurando começar pelas definições e em seguida pelos princípios, o que não é a maneira de proceder nessa espécie de raciocínio. Não quer isso dizer que o espírito não o faça; mas ele o faz tacitamente, naturalmente e sem arte, pois a expressão se adapta a todos os homens, e o sentimento só pertence a poucos homens. Os espíritos sutis, ao contrário, acostumados a julgar com um só golpe de vista ficam tão espantados - quando se lhes apresentam proposições das quais nada compreendem e cuja penetração exige anteriormente definições e princípios estéreis, que não estão acostumados a ver afastam e se desgostam. (pp. 41-42)

Pascal não privilegia o sentimento e nem a razão, na verdade tenta colocá-los em equilíbrio: 
Os que estão acostumados a julgar pelo sentimento nada compreendem das coisas do raciocínio, pois querem logo chegar a perceber com um golpe de vista e não têm o hábito de procurar os princípios. E os outros, pelo contrário, que estão habituados a raciocinar por princípios, nada compreendem das coisas do sentimento, procurando nelas princípios e não podendo vê-las de um golpe (1974 p. 43).

Logo, na perspectiva do pensador, a razão não deixa de ter importância, porque, segundo Pascal, mesmo limitados somos os únicos seres pensantes da natureza. Todavia, somos também um dos seres mais fracos da natureza. Ou seja, somos seres frágeis e pensantes. E no pensamento mora nossa dignidade, nossa nobreza e superioridade frente à natureza. Nós somos miseráveis e mortais, mas sabemos que somos miseráveis e mortais e nisso está nossa grandeza. Talvez, o autor queira nos trazer a ideia de humildade diante de nossas realidades, impedida pelo racionalismo.

Nesse sentido, o livro Pensamentos (1973) tenta mostrar que há uma infinidade de coisas que ultrapassa a razão, a qual se revela fraca, por não conseguir abarcar todos os princípios; por isso, Pascal afirma:

A razão age lentamente e com tantas vistas, sobre tantos princípios, os quais devem estar presentes, que a cada instante ela cochila ou se perde, deixa de ter todos os seus princípios presentes. O sentimento não age assim: age um instante e está sempre pronto para agir. É preciso, pois, pôr a nossa fé no sentimento; de outra maneira, vacilará sempre. Dois excessos: excluir a razão, só admitir a razão (ibidem, p. 108).

O pensador revela a importância do sentimento de amor que o outro nos transmite:

Quando as palavras espontâneas de alguém pintam uma paixão ou um efeito, encontramos em nós mesmos a verdade do que ouvimos, a qual não sabíamos que existisse, de maneira que somos levados a amar quem no-la faz sentir; porque não nos exibe o seu bem e sim o nosso; e, assim, esse benefício no-lo torna digno de ser amado, além do que essa comunidade de inteligência induz necessariamente nosso coração a amá-lo (PASCAL, 1974 p. 45) .

Pascal elucida parte de uma ideia desprezada por Descartes, lembrando que este considerava que as emoções atrapalham a lucidez da razão, enquanto Pascal passa a considerar as emoções como parte integrante da vida humana. Desse modo, inicia-se uma nova abertura para a consideração das emoções no âmbito humano. O ideal cartesiano de "Je pense donc je suis" (eu penso, logo existo) deve vir depois do "je suis" (eu sou) ou até do "je sens" (eu sinto): ("Je suis, donc je pense", ou "Je sens, donc je suis"). Existimos e depois pensamos (e não o contrário). 
Aprofundando a busca dessa possível síntese entre o objetivismo e o subjetivismo, chegamos ao estudo da representação de Michael Polanyi, que nos fornece substratos de uma dimensão pessoal do conhecimento, trazendo as bases para se fundamentar outra forma de compreensão do conteúdo racional. A nosso ver, essa outra perspectiva possibilita a articulação de metodologias para a explicitação de conhecimentos não verbalizados e de suma importância para o processo educacional. 


\section{BUSCA DA SÍNTESE NA REPRESENTAÇÃO DE MICHAEL POLANYI}

\subsection{Michael Polanyi e o Conhecimento Tácito}

"Provamos através da lógica, mas descobrimos a partir da intuição" (HENRI POINCARÉ)

Na Idade Moderna, para um conhecimento ser considerado científico, ele teria que ser um conhecimento objetivo, factual e rigoroso, não podendo tolerar a interferência dos valores humanos ou religiosos. Foi nesse contexto que se construiu a distinção dicotômica sujeito/objeto; tal distinção epistemológica teve de se articular metodologicamente com a distância empírica entre sujeito e objeto. Mas, Souza Santos (2011) nos esclarece que:

Hoje sabemos ou suspeitamos que as nossas trajectórias de vida pessoais e colectivas (enquanto comunidades científicas) e os valores, as crenças e os preconceitos que transportam são a prova íntima do nosso conhecimento, sem o qual as nossas investigações laboratoriais ou de arquivo, os nossos cálculos ou os nossos trabalhos de campo constituiriam um emaranhado de diligências absurdas sem fio nem pavio. No entanto, este saber das nossas trajectórias e valores, do qual podemos ou não ter consciência, corre subterrânea e clandestinamente, nos pressupostos não-ditos do nosso discurso científico (p. 84).

São exatamente sobre esses pressupostos não-ditos do nosso discurso científico que o filósofo Michael Polanyi (1891-1976) vai se debruçar, fornecendo-nos elementos para o entendimento da dimensão mais intrínseca do conhecimento (fusão da objetividade/subjetividade humana) e suas reverberações no processo educacional. Este capítulo, portanto, se concentrará nessa nova dimensão epistemológica na qual acreditamos encontrar a síntese do conhecimento. Em seguida, passaremos a tentar compreender quais são os impedimentos da construção saudável do saber. Acreditamos que as ideias de Polanyi foram fundamentais para se diagnosticar "a doença da mente moderna" provocada pela adoção somente de visão objetiva da realidade. (PROSCH, 1986, p. 49).

Polanyi nasceu na Hungria em 1891 e, apesar do amor pela química, estudou medicina, pois tinha receio de não ser aceito na universidade pelo fato de ser judeu. Começou sua carreira servindo o exército do Império Austro-Húngaro durante a $1^{\text {a }}$ Guerra Mundial, mas, como seu amor pela química era muito grande, tentou sua segunda carreira no Kaiser Wilhelm Institute em Berlim. Foi uma grande era para a ciência na Alemanha (início do século XIX), e Polanyi 
teve contato com importantes personalidades da época, como: Fritz Haber, Erwin Schrödinger, Max Planck e Albert Einstein. No entanto, ele teve que se mudar para a Inglaterra, em meados dos anos 30, com sua esposa e seus dois filhos, por causa da $2^{\mathrm{a}}$ Guerra Mundial. Nas terras inglesas, Polanyi trabalhou como professor de Físico-Química. Depois de muitos anos de sucesso em sua vida profissional, ele decidiu mudar e lecionar na cadeira de Estudos Sociais. Publicou muitos trabalhos em filosofia e economia. Seu último trabalho científico foi publicado em 1949 (PROSCH, 1986).

Polanyi andou na contracorrente dos estudos da época, trazendo uma abordagem totalmente nova no seu livro Personal Knowledge (Conhecimento Pessoal) (1958, 2013), segundo Prosch (1986):

Assim, Polanyi realizou um longo e exaustivo estudo de como chegamos a perceber e a entender - como "conhecer". Os resultados dessa investigação, ele publicou em sua obra principal, Conhecimento Pessoal, em 1958. Sua abordagem nesse trabalho foi um refrigério. Tendo abandonado a noção de que o conhecimento era pura objetividade, ele pensou ter visto que essa falsa noção de conhecimento como simples desapego ao sujeito conhecedor havia, de fato, estado impregnado em toda a filosofia ocidental. (...) Sua eventual descoberta do que ele acreditava ser a verdadeira epistemologia tornou-se, aos seus próprios olhos, um começo filosófico totalmente novo, um recuo nas formas atuais de lidar com os problemas do conhecimento, a fim de vê-los de uma nova perspectiva. Sua filosofia deve seu frescor, assim como seu efeito inicialmente intrigante $\mathrm{e}$ às vezes decididamente negativo sobre muitos filósofos contemporâneos, em grande parte ao fato de que ele não trabalhou explicitamente sobre os problemas particulares de conhecimento com os quais a maioria dos filósofos anglo-americanos se preocupou, nem sobre aqueles com que os filósofos clássicos trabalharam. Ele tendia a combater esses problemas e a levantar alguns pontos distintos sobre os quais os filósofos contemporâneos tinham dificuldade em encontrar suas bases (1986, p. 51). (Tradução nossa.)

A mudança para o campo filosófico se deu pelo fato de Polanyi estar envolvido com os questionamentos acerca dos problemas da relação entre a Ciência e Sociedade; ele engajou-se nos estudos sociais, especialmente nos econômicos, por causa da insistência dos socialistas na centralização planejada da economia como substituição do mecanismo de mercado do capitalismo privado. Ele viu, portanto, a necessidade de uma total revisão na visão da Filosofia da Ciência e do Conhecimento como única maneira de dissipar a ameaça à liberdade e à ciência em si, entendendo que o ideal de objetividade absoluta herdada da Revolução Científica do século XVIII tornaria o homem somente uma máquina de percepção.

Para o referido autor, como médico-filósofo, a filosofia não era meramente uma busca acadêmica, era propriamente um meio de vida. Foi sempre um crítico acirrado da visão positivista extrema da ciência, que influenciou e tem influenciado até hoje o pensamento 
moderno- não somente na Filosofia de Ciência, mas em muitas outras áreas também. Prosch (1986) esclarece no trecho abaixo, o desejo de Polanyi acerca da libertação da sociedade por meio de outros ideais científicos:

A importância e a respeitabilidade intelectual de manter firmes crenças sobre os ideais essenciais à Ciência e a uma sociedade livre - e um reconhecimento de sua interconexão - também se tornaram cada vez mais claras para ele (1986, p.49). (Tradução nossa.)

Mas, como foi possível ele criar uma epistemologia independente da objetividade de sua época? Sabemos que o ideal de rigor científico objetivo só aceitava o que poderia ser comprovado e que nenhuma doutrina moral era aceita como uma verdade. Assim, pela censura aos aspectos subjetivos do ser humano, a ciência deu brechas para as mais escabrosas manifestações de fanatismos, inversões morais, ideais messiânicos e totalitarismos no século XX.

Polanyi (1986) explica:

Minha busca me levou a uma nova ideia do conhecimento humano a partir da qual uma visão harmoniosa do pensamento e da existência, enraizada no universo, parece emergir. Reconsiderarei o conhecimento humano partindo do fato de que podemos saber mais do que podemos dizer. Este fato parece bastante óbvio; mas não é fácil dizer exatamente o que isso significa. Tomemos um exemplo. Conhecemos o rosto de uma pessoa e podemos reconhecê-la entre mil outros rostos ou até entre um milhão. No entanto, geralmente não podemos dizer como reconhecemos esse rosto conhecido. Portanto, a maior parte desse conhecimento não pode ser expressa em palavras (p. 51). (Tradução nossa.)

Polanyi, sem fundamentação na tradição ocidental, abraçou as concepções subjetivas de um conhecimento que não poderia se objetivar fora das pessoas, antes que só existia através dos sujeitos, reiterando, portanto, a hipótese de que o conhecimento é de ordem pessoal. Quando falamos do conhecer, falamos de pessoas. O autor afirma que não é comprando uma enciclopédia que compramos conhecimentos. É nesse contexto que nasce o livro Personal Knowledge (Conhecimento Pessoal) (1958), em que Polanyi discorre sobre o conhecimento pessoal contrapondo-se ao Objective Knowledge (Conhecimento Objetivo) de Karl Popper.

Na contramão, Polanyi se interessa exatamente pelo que Popper não quis conhecer, ou seja, pela maneira como recebemos os dados de fora e combinamos com nossos conhecimentos internos, o que denominou de conhecimento tácito em seu livro Tacit Knowledge (2013). O autor ilustra a sua ideia da seguinte forma: 
Estes poderes pessoais incluem a capacidade para compreender um significado, para acreditar numa afirmação factual, para interpretar um mecanismo relativamente ao seu propósito, e a um nível mais elevado, para refletir sobre problemas e para exercer originalidade na sua resolução. Incluem, sem dúvida, toda a forma para chegar a convicções por um ato de juízo pessoal (2013, pp. 269-270).

Polanyi nos desvenda o modus operandi do conhecimento quando postula que ele tem dois componentes: o proximal (subsidiário) e o distal (focal) e que eles se integram num ato perceptivo para trazer um significado inteligente e abrangente. Por exemplo, reconhecemos um rosto de uma pessoa no meio de uma multidão, confiamos em diversas características, como: a cor dos olhos, do cabelo, formato do nariz e do rosto, entre outros; isso faz parte da componente focal. Mas, o que buscamos é aquela pessoa específica na sua totalidade (distal) (o João ou a Maria) e para isso não nos focalizamos nas suas características específicas. Esse reconhecimento é feito no nível subsidiário tácito e por isso não conseguimos explicar como o fazemos. Seria a relação de um pormenor subsidiário indo para um foco, determinado pela ação do indivíduo, terminando na integração dos dois. Por isso, Polanyi (2013) afirma:

A apreensão subsidiária e a apreensão focal são mutuamente exclusivas. Se um pianista desvia a sua atenção da peça que está a tocar para observar antes o que os seus dedos fazem enquanto tocam, fica confuso e pode mesmo ter que parar. Isto acontece, em geral, quando mudamos a nossa atenção focal para os particulares de que estávamos anteriormente conscientes apenas pelo seu papel subsidiário (p. 58).

É sempre um sujeito conhecedor (com conhecimentos subsidiários) que, numa ação combinada com o componente focal (mundo explícito), produz o conhecimento de forma totalmente pessoal, promovendo significados a partir de incorporações de conhecimentos. 
Figura 1 - Dinâmica do conhecimento tácito

\section{Indivíduo \\ Conhecedor \\ subsidiário}
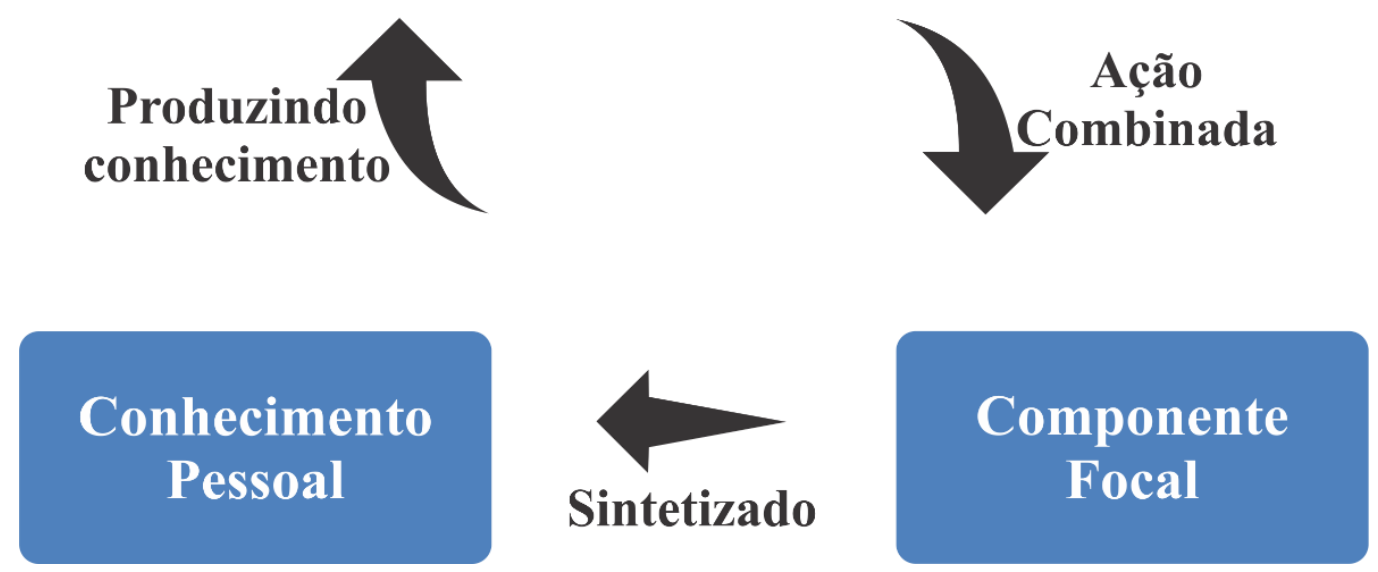

Fonte: da autora (2018)

Assim, "we keep expanding our body into the world, by assimilating to it sets of particulars which we integrate into reasonable entities" (Nós continuamos a expandir nosso corpo no mundo, assimilando a ele conjuntos de particulares, os quais integramos em entidades razoáveis) (POLANYI, 1983, p. 29). Portanto, é desse modo que Polanyi entende o conhecimento. É a partir de um sujeito que já tem um conhecimento interior, que parte para o mundo externo (explícito), sempre em ação, sintetizando novamente no indivíduo e produzindo mais conhecimento. O exemplo clássico de como aprendemos a andar de bicicleta é uma das melhores explicações para esse tipo de conhecimento. Já tenho noções dentro de mim de todo o processo, pego a bicicleta (mundo explícito) e na ação, sintetizo o conhecimento.

Polanyi inaugura, portanto, uma nova epistemologia em seu livro Personal Knowledge (1958), transcendendo a dualidade objetivismo/subjetivismo, de forma a estabelecer um processo de assimilação interior que "we can know more than we can tell" (nós podemos saber mais do que nós podemos dizer) revela que possuímos um conhecimento tácito, o qual não pode ser verbalizado, formalizado, codificado em palavras ou transmitido. De certo modo, o autor propõe a percepção de uma instância de um conhecimento inato em um sujeito conhecedor.

Esse conhecimento mostra apenas a ponta visível do iceberg e todo o corpo imerso constituiria o conhecimento legítimo, ainda não conceitual, e até mesmo sem nenhuma realização verbal. Tal conhecimento legítimo é pessoal, só o indivíduo que o possui pode exercê-lo de forma consistente. Um de seus exemplos clássicos (1966), já citados acima, é a 
maneira pela qual aprendemos a andar de bicicleta. Trata-se de uma física complexa, nenhum ciclista conhece, de fato, a física envolvida em tal aprendizagem, e se os ciclistas a conhecessem não seriam capazes de usá-la para andar de bicicleta. Assim, todo conhecimento envolve uma ação habilidosa do sujeito "conhecedor” (POLANYI, 1983, P.16).

Desse modo, o conhecimento tácito produz sempre ações orgânicas de interação; proporcionando experiências inéditas, as quais são sempre assimiladas a partir do conhecimento de que o indivíduo já dispõe, conhecimento de natureza subsidiária. Exatamente, como no exemplo dado anteriormente, é no instante em que reconhecemos o rosto de uma pessoa no meio de milhares ou milhões de indivíduos sem poder dizer ou descrever em palavras como o reconhecemos. Nesse sentido, o autor traz um novo elemento de composição para se pensar a construção de conhecimento, pois abre perspectiva de reflexão para além do racional, do objetivo. Muito do que vivemos na vida é vivido na antessala do logos com seus conceitos e elaborações (área do pré-conceitual). Já podemos, então, vislumbrar que nem tudo precisa ser medido, provado e comprovado para ter um significado linguístico ou científico.

Assim, Polanyi (2013) nos esclarece como sentimos nosso caminho para o sucesso:

Este é o processo habitual de tentativas inconscientes pelo qual sentimos o nosso caminho para o sucesso e pelo qual o podemos continuar a melhorar, sem sabermos de forma especificável como é que o fazemos - porque nunca encontramos as causas do nosso sucesso como coisas identificáveis que possam ser descritas em termos de classes de que essas coisas sejam membros. É assim que se inventa um método para nadar, sem saber que consiste em regular a respiração de uma forma particular, ou se descobre o princípio de andar de bicicleta sem perceber que consiste em ajustes da direção e da velocidade instantânea para contrabalançar permanentemente o desequilíbrio instantâneo acidental. Logo, a descoberta prática de uma ampla gama de regras não conhecidas conscientemente, acerca de competências hábeis e dos conhecimentos práticos, incluem importantes processos técnicos que raramente podem ser completamente especificados, e mesmo assim apenas como resultado de uma extensa investigação científica. (p.65)

No caso, um cientista, por exemplo, é altamente influenciado pelos valores e pelas emoções sentidas no decurso do seu trabalho, fato que denota um coeficiente pessoal omnipresente de conhecimento que é tácito, pré-científico e pré-conceitual. Desta forma, se a componente tácita é parte indispensável de todo e qualquer conhecimento, a ideia de eliminar os seus aspectos pessoais equivale à destruição do conhecimento em si mesmo. Ele diz respeito à descoberta e constitui a base para o conhecimento explícito, e nele reside o potencial para encontrar a referida alternativa estável à objetividade. É nesse sentido que consideramos Polanyi como a expressão da síntese entre o conhecimento objetivo e o subjetivo. 
Partindo dessa síntese e considerando, portanto, a apreensão do significado como um processo que deve ser entendido a partir de vários elementos (colocando o universo interior como primeiro campo de experiência), o postular de Polanyi desafia a articulação consciente, o que significa que podemos não estar alertas quanto ao modo como as ações inconscientes influenciam nossos comportamentos. Desse modo, podemos dizer que precisamos da experiência para, numa ação compartilhada, deixar o saber se manifestar.

No processo educacional, busca-se a explicitação dos conteúdos de cada aluno, principalmente nos processos avaliativos. No entanto, essa explicitação não pode ter a sua base subsidiária ignorada. Dar um contexto a uma questão de uma prova é enunciá-la de maneira que favoreça a explicitação do conhecimento subsidiário dos alunos. Ignorar esse contexto é se concentrar apenas no modo como o professor ou o aluno diz isto ou aquilo, sem atingir o verdadeiro significado das coisas, que só seria possível através da estimulação de "links" que favorecem a expressão dos conhecimentos tácitos implícitos dos alunos. É nesse sentido que a visão de Polanyi é importante para o processo educacional, pois indica que o professor deve ser mais um facilitador dos conhecimentos subsidiários que já estão à espera de serem explicitados.

Dessa forma, pode-se dizer que Polanyi tentou curar a mente moderna de suas mais intensas aflições e doenças, uma vez que esta, ao enxergar apenas pelo prisma racional (explícito), reduz as possibilidades subjetivas e renega o que o conhecimento tem de mais valioso, que é o subsidiário. Percebe-se que muitas são as consequências de não se considerar tais valores internos do indivíduo. A principal é construir um modelo de sociedade que não reflete sobre si mesma, sobre seus fatores econômicos, sociais e ambientais.

A saudável ação combinada entre conhecimento tácito e explícito abre possibilidades incríveis de desenvolvimento científico, social e educacional, já que o conhecimento acaba sendo "processado" em nível do pré-conceitual, o que inibe a imposição de conhecimentos indutivos sem relação com o indivíduo conhecedor e, portanto, sem relação com a realidade. $\mathrm{O}$ conhecimento pessoal de Polanyi (2013) nos leva à valorização do conjunto, em detrimento das partes. Vejamos o seguinte exemplo:

Os particulares de um padrão ou de uma melodia devem ser apreendidos em conjunto, pois se observarmos os particulares em separado, eles não formarão um padrão ou uma melodia. Pode-se argumentar que se eu atender ao padrão ou à sinfonia como um todo, isso implica a sua apreciação como um padrão ou como uma sinfonia, o que será contraditado se mudar a minha atenção focal para as notas isoladas da sinfonia ou para os fragmentos do padrão. Mas talvez seja melhor formular esta contradição em termos mais gerais, dizendo que a nossa atenção só pode suportar um foco de cada vez, e que será 
autocontraditório estar consciente, tanto subsidiária como focalmente, dos mesmos particulares ao mesmo tempo. (p. 59).

Nesse sentido, os profissionais de qualquer área do conhecimento têm que partir do todo para as partes, operando processos inefáveis que não podem ser explicados. Se um professor de inglês, por exemplo, der muita importância às estruturas particulares da língua, como repetição fonética ou gramatical, ele vai dificultar a apreensão do idioma, que pode ser feita pelo conjunto global. O exemplo caseiro de Polanyi é interessante para entendermos melhor a apreensão do todo em detrimento do particular:

Os portadores mais eficientes de significado são naturalmente as palavras de uma linguagem, e será interessante recordar que quando usamos palavras num discurso, ou na escrita, apenas estamos conscientes delas de uma forma subsidiária. Este facto, que usualmente é descrito como a transparência da linguagem, pode ser ilustrado por um episódio da minha própria experiência caseira. Ao pequeno-almoço recebo a minha correspondência em várias línguas, mas o meu filho só compreende o inglês. Acabada de ler uma carta, posso querer passá-la para ele, mas preciso de voltar a verificar em que linguagem é que está escrita. Estou bem consciente do sentido transmitido pela carta, mas na realidade nada sei sobre as suas palavras. Atendi-lhes atentamente, mas apenas por aquilo que significam e não por aquilo que são como objetos. Se a minha compreensão do texto fosse interrompida, ou se as suas expressões ou a sua grafia estivessem erradas, as suas palavras teriam chamado a minha atenção. Tornar-se-iam algo opacas e impediriam que o meu pensamento passasse por elas sem problemas, na direção das coisas que significam (2013, p. 59).

O trabalho de Polanyi torna-se muito importante no campo de ensino e aprendizagem de línguas estrangeiras, em que o processo de captação do sentido pelo todo é essencial. Não ensinamos tudo para os alunos. Muito da pronúncia não se ensina, por exemplo. No entanto, os alunos captam de nós até o que não ensinamos. É a força do todo influenciando os particulares. Todo professor pode fazer a experiência de pedir um material escrito pelos alunos, seja em caderno, bloco ou tablet, e verificar que, muitas vezes, os alunos escrevem determinados conhecimentos que o professor não ensinou.

Quando Werner von Braun, cientista alemão de engenharia de foguetes (1912 - 1977) explanou: "Basic research is what I am doing when I don't know what I am doing" (Pesquisa básica é o que eu faço quando eu não sei o que estou fazendo), ele exemplificou que nenhum conhecimento pode ser inteiramente articulado. O conhecimento é mais um estado no qual se começa o processo numa ação específica, permanece-se neutro esperando o que vem e depois interage novamente e assim por diante. Podemos dizer que é sempre uma descoberta nova 
partindo do que sabemos para o que não sabemos ainda; um reconhecimento que surpreende sempre.

Professores de alfabetização têm essa experiência quando alunos de diferentes idades e em diferentes épocas do ano letivo aprendem a ler. Não é verdadeiramente uma aprendizagem, mas uma revelação que se expande no interior da criança a partir do momento que entrelaça o conhecimento tácito subsidiário com o explícito. Geralmente há muita alegria e bem-estar no processo porque a dinâmica traz novas perguntas, novos interesses e novos questionamentos e, nesse momento, a criança (e o professor) se dá (dão) conta que fez (fizeram) contato com a realidade. É o que Polanyi chama de paixão intelectual.

Seria mais um jogo em que inicialmente partimos de uma ação consciente e, em seguida, navegamos um pouco mais em uma inconsciência a caminho da descoberta. Surpreendentemente o todo se revela de uma vez, incorporando e revelando o conhecimento. Quando escutamos duas ou três notas de uma música, por exemplo, às vezes, reconhecemos a música inteira na cabeça antes que tenha sido tocada. O exemplo do uso de aspas de Polanyi, explica bem o poder cognitivo subsidiário do qual não nos damos conta:

Podemos tentar usar uma ferramenta, ou simplesmente mostrar que não tem utilidade. De forma semelhante podemos usar uma palavra descritiva com ceticismo, pondo-a entre aspas. Suponha-se um artigo publicado com o título Uma explicação da "percepção extra-sensorial", e outro, de resposta a este, intitulado Uma "explicação" da percepção extra-sensorial. Guiados pelas aspas, reconhecemos imediatamente que o primeiro artigo considera a percepção extra-sensorial como espúria, enquanto que o segundo acredita que seja genuína e desacredita, pelo contrário, a explicação sugerida pelo primeiro artigo. As palavras descritivas escritas como parte de uma frase, sem aspas, são invocadas com confiança: credenciam o carácter substancial do conceito que transmitem e a sua pertinência para o assunto em questão. Chamarei a isso o uso confiante ou direto de uma palavra. Por oposição, uma palavra descritiva usada entre aspas (como parte de uma frase não relativa a essa palavra) é usada numa forma cética ou oblíqua. Esse uso põe em questão a realidade do conceito evocado pela palavra assim como a sua aplicabilidade ao caso em questão. Como uma palavra continua a ser a mesma, quer usada direta quer obliquamente, a diferença entre a sua afirmação confiante ou cética deve residir totalmente no coeficiente tácito da sua afirmação. Esta diferença identifica formalmente o coeficiente pessoal não especificável associado ao uso confiante de um termo descritivo (2013, p. 255).

O processo educacional, por conseguinte, pode levar em conta a perspectiva de Polanyi de forma a trabalhar com uma visão mais interconectada dos fenômenos e das disciplinas. Pode, de certo modo, começar pela interação pessoal, subjetiva, em que "incorporamos tacitamente elementos inefáveis que se expressam com um olhar, com um gesto, com um sorriso, que não conseguimos expressar em palavras, mas que compõem, legitimamente, os processos 
cognitivos" (ARANTES, 2003, p. 231-232). Conjuntamente, é preciso ter em vista que tudo acontece com um certo controle intelectual, combinado com certas antecipações do saber. Assim, Polanyi conclui:

Logo, o nosso sentimento de possuir um controle intelectual sobre uma variedade de coisas combina sempre uma antecipação por encontrar certas coisas deste tipo, que serão novas a respeito de certas características não especificáveis, com a confiança em nós próprios para as interpretar, com sucesso, através de modificações apropriadas do nosso quadro interpretativo de antecipações (POLANYI, 2013, p. 106).

Ainda hoje educadores pensam que a realidade está a nossa disposição de forma impessoal e morta. Nós despersonalizamos a realidade para poder trabalhar com ela, controlála, de forma a fazer o que bem entendemos. Mas, não é assim. Segundo Polanyi (2013), a realidade está interagindo conosco o tempo todo. É sempre uma aventura. Temos que nos abrir para o entendimento de forma ativa, apreciar e ter consciência do fenômeno, o que o autor denominou de Indwelling.

\subsection{Indwelling}

Polanyi (2013) denomina de Indwelling a integração de elementos particulares a uma entidade coerente, passando por uma expectativa contemplativa. Seria um processo espontâneo e fora do nosso controle consciente, em que ativamos os nossos recursos tácitos subsidiários, formando conjecturas a partir da seleção de material mobilizado pela imaginação, de modo a incorporar elementos imaginativos e criar novas soluções aos problemas.

Se estivéssemos esperando o entendimento só dos particulares, em si, quer dizer, se esperássemos significados só dos fatores externos a nós, não poderíamos identificá-los, mas se considerarmos a integração dos particulares como uma incorporação (interiorização), o panorama fica muito mais claro. Assim, Polanyi atesta:

Torna-se agora um meio de fazer com que certas coisas funcionem como os termos proximais do conhecimento tácito, de modo que, em vez de observálas em si mesmas, possamos estar cientes delas em relação à entidade abrangente que elas constituem. Isso nos traz de volta para casa; não é olhando para as coisas, mas por habitar nelas, que entendemos seu significado conjunto (ibidem, p. 18). (Tradução nossa.)

As observações astronômicas de um cientista, por exemplo, são feitas vivendo uma teoria astronômica, e é essa satisfação interna com a astronomia que cria o interesse do 
astrônomo sobre as estrelas. Se olharmos um mapa secamente e sem subjetivação, não vamos ver o valor científico do experimento. Para Polanyi, o interesse é contemplativo:

É assim que o valor científico é contemplado interiormente. Mas a consciência dessa satisfação perde-se quando as fórmulas da astronomia são usadas de forma rotineira. Só quando se reflete sobre a sua visão teórica, ou se experimentam conscientemente os seus poderes intelectuais, é que se pode dizer que se está a contemplar a astronomia (POLANYI, 2013, p. 199).

Assim, pela teoria proposta, nota-se que é pela intersecção da união entre o nível subsidiário do conhecimento e dos particulares que incorporamos a aprendizagem. Tal incorporação perfeita é a Indwelling. Um cego que usa uma bengala, por exemplo, inicialmente sente na mão quando o instrumento bate no chão. Mas depois de um certo tempo, passa a sentir a bengala como uma extensão de seu corpo e ela passa a residir nele. $\mathrm{O}$ sujeito a incorpora em si mesmo. Outro exemplo, é quando aprendemos a dirigir. Inicialmente parece que somos duas entidades separadas, mas depois de um certo treino (ação), estendemo-nos ao limite espacial do carro, passa a ser parte de nós, dando-nos a possibilidade e as habilidades de fazermos proezas no volante. De certo modo, o conhecimento subsidiário é incorporado totalmente pela pessoa, depois é inteiramente processado.

Quando um professor está ensinando, e os alunos estão prestando atenção nos procedimentos da aula, eles estão incorporando o professor. Quando o docente mexe a mão, possivelmente os estudantes estão pensando e tentando saber o significado de todas as ações. É por isso que muitas vezes os alunos aprendem coisas que o professor não ensinou. Os estudantes estão interconectando os saberes tácitos com o explícito a todo momento, e o professor deve ser o facilitador desse processo. Outro exemplo é quando os admiradores de arte acham elementos no quadro que o artista não pintou intencionalmente.

Posso mesmo dar o meu exemplo pessoal: quando estudava francês, aos 12 anos de idade, tive uma professora muito especial, que me fez decidir ser professora. Eu admirava muito as suas aulas dinâmicas e atrativas. Cada ato dela era um deleite para mim, e eu me deliciava a cada momento da aula. Era uma expectativa gostosa de novidade e eu incorporava tudo com o maior interesse nos mínimos detalhes. Até hoje faço uso do que incorporei das aulas dela. Evidentemente que minha apreensão subsidiária e focal hoje é a combinação do que incorporei dela com minhas próprias ações, produzindo mais significações dinâmicas. Esse exemplo pode ilustrar a percepção de Polanyi (2013) abaixo: 
A reconstituição do conhecimento pessoal até as suas raízes, na apreensão subsidiária do nosso corpo como fundido com a nossa apreensão focal de objetos externos, revela não só a estrutura lógica do conhecimento pessoal, mas também as suas origens dinâmicas (p. 63).

Tendo esses conhecimentos de Indwelling, o educador deve buscar compreender o nível metafísico que se apresenta. Não é a informação passiva que vai ser friamente entendida pelos alunos. Peguemos o exemplo de uma tabela de verbos em inglês: para que os alunos os aprendam, eles vão precisar que aconteça algo a mais do que só a informação à sua frente; vão precisar de um engajamento dinâmico do conhecimento tácito, numa paixão intelectual. Quando a pessoa se engaja no assunto, já está incorporando o conhecimento (Indwelling). A habilidade de um motorista nunca poderá ser substituída pelo ensino em uma autoescola. E nem o conhecimento das regras de rima e de prosódia nos farão entender o que um poema nos transmite. Nós, como pessoas operativas, “derramamo-nos nós próprios nas nossas operações, assimilamo-las como parte de nossa própria existência. Aceitamo-las existencialmente, vivendo e habitando (dwelling) nelas." (POLANYI, 2013, p. 62)

É um processo transformador - e se não for assim, parece que o aluno não aprende, e o professor não ensina. $\mathrm{O}$ educador tem de estar aberto e ciente de que ele não sabe o que vem pela frente. É sempre um reconhecimento surpreendente, atraente, divertido e encantador a novidade e a surpresa da Indwelling. Talvez, essa seja a explicação de morarmos com uma pessoa por 10, 20 ou 30 anos e volta e meia nos surpreendermos com alguma atitude inesperada dela.

É importante ter em conta que podemos destruir nosso entendimento de assuntos complexos pela descontrolada lucidez da nossa ciência positivista. Se escrutinarmos de perto só os particulares para melhor entendê-los, acabaremos por perdê-los e destruiremos a capacidade de abarcar o todo. Se repetirmos palavras várias vezes, prestando atenção somente nos movimentos dos lábios e da língua para perceber o som que se faz, podemos perder eventualmente o sentido do que se ensina, uma vez que a aprendizagem se torna vazia e estéril. Se um pianista fica prestando atenção nos seus dedos, tirando o foco da música que executa, pode, temporariamente, paralisar os seus movimentos.

Outra forma de destruição das possibilidades de significação pela indwelling é quando um aluno tira uma nota baixa numa prova, e já é excluído do contexto harmônico da aula. Ou, quando um aluno que está motivado e quer ir mais além do que é ensinado na aula não encontra espaço por causa do enquadramento objetivo dos métodos tradicionais de ensino, que seguem determinados pré-requisitos. Assim, os sistemas objetivos de avaliação podem funcionar como 
fatores inibidores do processo de aprendizagem, por estarem bloqueando a percepção tácita e o encadeamento de significações.

No entanto, se voltarmos a incorporar os particulares, se as palavras forem proferidas novamente em um contexto adequado e o pianista usar sua mente com suas mãos em prol da música, tudo volta à vida e recobra seus significados e relações de compreensão. Deste modo, estaremos de volta à convicção de que sempre há algo a ser descoberto.

Em algum momento, alunos estimulados corretamente vão compreender que podem inventar ou reinventar algo a partir de alguma coisa. É nesse momento que, possivelmente, estaremos conseguindo ler o que antecede o conhecimento. Nessa hora, entra a função do professor, que deve tentar usar maneiras adequadas para o resgate das competências tácitas dos alunos. Em primeiro lugar, o docente deveria ter a preocupação de procurar a captação desse significado em sua própria vida, buscando meios de atualização constantes, completando o que vê com aquilo que sabe, estabilizando e interpretando as informações, dando-lhes significado.

Pode ser um tanto quanto difícil essa volta à percepção dos fenômenos interiores, porque estamos muito habituados ao uso do conhecimento objetivo de classificação e de interpretação do mundo. Entretanto, esse paradigma adotado já não responde mais a nossos anseios. Precisamos de novos caminhos, que nos levem a conhecimentos mais profundos e nos façam compreender que podemos reinventar, abstrair, amar e agir, chegando mais à essência dos seres e das coisas, a partir de conhecimentos pré-existentes em nosso interior, combinados com o universo externo.

\subsection{Polanyi e a Educação}

Por ter sido médico, filósofo e cientista, Polanyi reuniu qualidades suficientes que lhe deram base para fazer não somente uma nova abordagem subjetiva do conhecimento, mas também uma síntese do objetivo com o subjetivo. Não só criticou o afã positivista da ciência com sua razão cartesiana e iluminista, mas também trouxe uma filosofia científica, que não pretendia defender uma subjetividade extremada, antes almejava estabelecer uma pessoalidade, em que o indivíduo pudesse sempre conhecer mais do que pode expressar. Por isso, debruçouse decisivamente sobre a dinâmica da percepção, incluindo-a como parte integrante dos processos cognitivos, em vez de deixá-la de fora, como o fizera Popper (MACHADO, 2015).

Essa percepção defendida por Polanyi (2013) pode ser lida diretamente como o papel das paixões na ciência: 
[...] cheguei agora ao momento em que pretendo lidar explicitamente com o papel das paixões na ciência. Quero mostrar que as paixões científicas não são meros subprodutos psicológicos, mas antes que têm uma função lógica, que contribui com um elemento indispensável para a ciência. Respondem a uma qualidade essencial numa afirmação científica e, de acordo com isso, podem ser ditas como sendo verdadeiras ou erradas, dependendo de se reconhecer ou negar nela a presença dessa qualidade. Qual é essa qualidade? As paixões carregam os seus objetos com emoções, tornando-os repulsivos ou atrativos; as paixões positivas afirmam que alguma coisa é preciosa. A excitação de um cientista ao fazer uma descoberta é uma paixão intelectual, que diz algo que é intelectualmente precioso e que, mais em particular, é precioso para a ciência. E esta afirmação faz parte da ciência (pp.137-138).

Imaginemos ser essas descobertas de paixões intelectuais o ponto principal de condução dos nossos alunos. Isso porque revelam um conhecimento novo; contudo, segundo Polanyi, esse conhecimento é apenas uma nova visão a que chegamos, pois o conhecimento é uma conjectura, é uma antecipação de coisas ainda desconhecidas.

Levando essa nova epistemologia de Polanyi especificamente para o campo do ensinoaprendizagem de línguas, podemos notar, em primeiro lugar, que suas ideias fazem uma clara distinção entre a apreensão do conhecimento, a partir de uma assimilação de experiências, por uma estrutura interpretativa fixa objetiva, e a adaptação dessa estrutura, englobando as lições de uma nova experiência. A estrutura, nesse caso, é articulada. Vejamos como explica o uso da língua:

A primeira representa o ideal de usar a linguagem de forma impessoal, de acordo com regras estritas; a segunda baseia-se numa intervenção pessoal de quem fala, para alterar as regras da linguagem que se adaptam às novas ocasiões. A primeira é uma performance de rotina, a segunda é um ato heurístico. Um paradigma da primeira é a contagem, que deixa o quadro interpretativo - os números usados na contagem - sem alteração significativa; o ideal da segunda encontra-se na originalidade das frases poéticas ou nas novas anotações matemáticas associadas a conceitos novos. Idealmente, o primeiro é estritamente reversível, enquanto o segundo é essencialmente irreversível. Modificar o nosso idioma é modificar o quadro de referência dentro do qual devemos doravante interpretar a nossa experiência; é modificar-nos a nós próprios (POLANYI, 2013, p. 108).

Podemos entender que o uso de uma língua depende muito mais da articulação que fazemos de nossas estruturas internas, em uma intervenção pessoal (paixão intelectual), ao mudarmos as regras do idioma para nos adaptarmos e nos encaixarmos em novas situações. Esse entendimento está se mostrando fundamental para analisar melhor o nosso modo de ensinar, já que nós, professores, não somos meros repassadores de informações e automatismos. 
Para Polanyi, temos um modo bem pessoal de significação, e isso nos mostra a necessidade de reflexão sobre como lidar com as significações no caso particular de cada um de nossos alunos e o reflexo disso na educação em geral.

\begin{abstract}
Devo admitir agora que não iniciei esta reconsideração das minhas convicções com um estado limpo de incrédulo. Longe disso. Comecei com uma pessoa intelectualmente moldada por um idioma particular, adquirido pela minha afiliação com uma civilização prevalecente nos locais onde cresci, neste período particular da história. Esta foi a matriz de todos os meus esforços intelectuais. Todas as minhas alterações a estes termos originais continuam incorporados nas minhas convicções anteriores. Nada posso dizer com precisão. As palavras que disse e que ainda vou dizer nada significam: só eu é que posso significar algo pelo seu uso. E, por regra, até um certo ponto, acredito que as minhas palavras (palavras descritivas) devem significar mais do que eu possa saber, se é que podem significar seja o que for. (POLANYI, 2013, pp. 35-36).
\end{abstract}

Nesse sentido, um professor que se proponha formar pessoas inteligentes e felizes deve propiciar oportunidades de articulação e explicitação dessas estruturas pessoais do conhecimento embasadas na nossa herança cultural. Polanyi (1983, p. 35-36) nos fornece um exemplo interessante:

Quando pronunciamos um discurso em que inclui 5 níveis: 1. A voz pronunciada; 2. As palavras; 3. As sentenças; 4. O estilo; 5. A composição literária. Cada um destes níveis está sujeito às suas próprias leis por estarem prescritos pela: 1. Fonética; 2. Léxico; 3. Gramática; 4. Estilos; 5. Crítica literária. Estes níveis formam uma hierarquia de entidades compreensivas para que os princípios de cada nível operem sob o controle do nível superior seguinte. A voz que produzimos está moldada em palavras pelo vocabulário; um dado vocabulário está moldado em sentenças de acordo com a gramática; e as sentenças podem ser feitas para se encaixar em um estilo que por sua vez é feito para expressar as ideias da composição literária. Portanto, cada nível está sujeito ao controle duplo; primeiro pelas leis que são aplicadas para seus elementos em si mesmos e, segundo, pelas leis que controlam as entidades compreensivas formadas por elas. Deste modo, as operações de um nível superior não podem ser levadas em conta pelas leis que governam seus particulares formando o nível inferior. Você não pode obter um vocábulo da fonética; você não pode obter uma gramática de uma língua de seu vocabulário; o correto uso da gramática não leva em conta um bom estilo linguístico; e um bom estilo não proporciona o conteúdo de uma prosa. Nós podemos concluir, portanto, em confirmação ao que eu já havia dito, quando identifiquei dois termos do conhecimento tácito com os dois níveis de realidade, que é impossível representar os princípios organizadores de um nível superior pelas leis que governam seus particulares isolados (1983, p. 35-36). (Tradução nossa.) 
Mas como levar esses princípios organizadores de um nível superior ao processo educacional? Especialmente no ensino de línguas estrangeiras, muito da pronúncia e entonação, não se ensina aos alunos, pois cada um capta de uma maneira muito particular, sutil, em diferentes momentos e de uma forma global.

O grande desafio do professor, então, seria privilegiar o aspecto do conhecimento a partir desse prisma subsidiário de nível superior, que governa os particulares, e estruturar formas e atividades que exercitem a conexão entre o conhecido e o ainda desconhecido, de modo a propiciar a explicitação desse conhecimento infuso de forma significativa. Os alunos adquiririam competência para se expressarem, contextualizarem, imaginarem, argumentarem e decidirem plenamente. Só é possível "adquirir" conhecimento quando o indivíduo se encontra em contato direto com situações que propiciam novas experiências, as quais são sempre assimiladas através dos conceitos de que o indivíduo dispõe - por natureza, tácitos. Quando novas palavras ou conceitos são inseridos nesse sistema de linguagem previamente existente, influenciam-se mutuamente, na medida em que o próprio sistema enriquece os novos conceitos introduzidos. É assim que todo o conhecimento se funda numa dimensão tácita (CARDOSO, 2007).

Nós, educadores, não podemos nunca perder a esperança com nossos alunos. O estímulo tem que ser constante, como se estivéssemos a semear num campo a ser semeado sempre - e a preocupação deve ser com o futuro e não com o presente imediato. Um aluno pode levar muito mais tempo para apreender um conteúdo do que seus colegas, mas isso não significa que não aprendeu. Significa apenas que não foi o seu momento para o desvendar do significado. Mas se um professor estimulá-lo de outra forma ou em outro momento mais adequado, o estudante poderá manifestar seu conhecimento tácito até mais solidamente que seus colegas, que o fizeram com maior rapidez. Vamos tentar explicitar, mais adiante no trabalho, alguns possíveis aspectos impeditivos que podem cercear a relação maior com o nosso mundo tácito.

Temos de considerar também que muitos alunos, com certas dificuldades de aprendizagem, não têm tido chances de reverter o quadro, por causa das próprias metodologias cartesianas de ensino e das avaliações, que não deixam oportunidades de estabelecimento de contato com o nosso conhecimento. No caso do ensino de línguas, muitos alunos sofrem com professores que exigem deles um desempenho eficiente e rápido, igual para todo o restante da classe. A tendência geral de alguns estudantes é se retraírem; passam a ter medo de falar, porque não lhes foi dado o tempo necessário para se relacionarem com o conhecimento interior tácito. Muitas vezes, temos que deixá-los falar errado, deixá-los se expressar, para que adquiram confiança através da prática, assim poderão manifestar seus conhecimentos subsidiários. Temos 
também que criar exercícios que facilitem tala manifestação. Polanyi elucida isso com o seguinte exemplo:

\begin{abstract}
uma situação onde duas pessoas partilham o conhecimento de uma mesma entidade - de uma ação em que um deles executa e o outro apreende. É o caso quando uma pessoa formula uma mensagem e outra a recebe. Mas as características específicas de uma situação assim são melhor percebidas se considerarmos a maneira pela qual uma pessoa passa a entender as habilidades de outra. Por exemplo, o aluno deve tentar combinar mentalmente os movimentos que o mestre combina na prática e ainda combiná-los conforme um padrão semelhante ao padrão de movimentos do professor. Dois tipos de experiência interna (Indwelling) ocorrem aqui. O professor coordena seus movimentos concentrando-se neles como partes de seu próprio corpo, enquanto o observador tenta correlacionar esses movimentos, numa tentativa de vivenciálos fora, a partir do exterior. O aluno capta a essência desses movimentos interiorizando-os. Através desse processo exploratório de interiorização (Indwelling) o aluno vai absorvendo a habilidade do mestre e pode até mesmo aprender o suficiente para rivalizar com ele (POLANYI, 1958, p. 29). (Tradução nossa.)
\end{abstract}

Um processo educacional, que se proponha a formar personalidades criativas e inteligentes, deve propiciar oportunidades para que professores e alunos, através da transdisciplinaridade, das artes e da cultura, em uma ação engajada, possam fomentar Indwellings. Devemos estimular o olhar criativo dos nossos alunos, fazendo com que eles percebam que as incorporações são plenas de significados. Essas ações podem ser feitas de uma maneira bem mais simples do que imaginamos, basta percebermos a nossa intenção; afinal só podemos ver o invisível se estivermos procurando por ele. E é na procura que a ação vai ser determinante.

A partir do momento que entendermos, como afirma Marina (2009), que a inteligência é, acima de tudo: a aptidão para organizar comportamentos, descobrir valores, inventar e sustentar projetos, ser capaz de se libertar do determinismo da situação, resolver problemas e saber colocá-los; poderemos construir bases novas para a representação do conhecimento. Para tal intento, entendemos que precisamos deixar claras as manifestações não articuladas da inteligência, com base no que Polanyi (2013) chama de "fazer hábil":

Rasgando o ecrã de papel dos gráficos, das equações e dos cálculos, tentei pôr a nu as manifestações não articuladas da Inteligência, pelas quais nós conhecemos as coisas de uma forma puramente pessoal. Entrei numa análise das artes práticas do "fazer hábil" e do "conhecer competente", cujo exercício guia e credencia o uso de fórmulas científicas, e que se estende muito para além disso, sem a ajuda de qualquer formalismo, ao conformar as nossas noções fundamentais sobre a maior parte das coisas que constituem o nosso mundo (2013, p. 67). 
Temos de estimular os nossos alunos, porque não existe percepção sem estímulo, mas o estímulo não determina a percepção. Há um espaço entre os dois que permite a capacidade de ver (olhar inteligente). Temos de ser facilitadores desse processo. No caso mais específico do ensino de línguas estrangeiras, não basta saber um idioma para ensinar, temos que inovar constantemente e não tentar encadear informações de modo cartesiano o que fazemos, por exemplo, ao partirmos de um verbo mais comumente utilizado, como o "to be", para depois trabalharmos classes gramaticais e sintáticas de forma fragmentada, dando exercícios repetitivos para memorização.

Outro elemento muito importante trazido por Machado (2009) relaciona-se às narrativas, quanto mais tacitamente elas forem apreendidas, mais o professor terá chances de atingir o significado com seus alunos. Assim, o professor deve sempre procurar trazer novos elementos para fomentar as relações com o que os alunos já trazem tacitamente; isso é absolutamente enriquecedor porque nasce sempre algo novo, o protótipo de um compromisso intelectual conosco e com nossos alunos, como Polanyi (2013) afirma:

As artes de fazer e de conhecer, a avaliação e a compreensão do significado, são apenas aspectos diferentes do ato de estender a nossa pessoa à consciência subsidiária dos particulares que compõem o todo. A estrutura inerente deste ato fundamental de conhecer pessoal torna-nos necessariamente participantes na sua conformação, e reconhece uma intenção universal aos seus resultados. Este é o protótipo de um compromisso intelectual (p. 68).

Poderíamos dizer que o conhecimento tácito é também objetivo, no sentido em que faz contato com uma realidade escondida. Contato esse que é definido como a condição para a antecipação de um leque indeterminado de objetos ainda desconhecidos. Resultando da fusão entre as dimensões pessoal e objetiva, o conhecimento pessoal contém um compromisso intelectual. Nessa linha de raciocínio, os trabalhos de Polanyi (1966/1997) são altamente dissonantes da concepção comum de ciência, que visa à obtenção de conhecimento impessoal e universal, à objetividade e ao rigor absoluto.

Também temos de estar atentos a que a maior parte do que ensinamos não tem eco mais profundos nos alunos. Parecem estar ali, participando e aprendendo, no entanto, pouca competência está sendo desenvolvida. Nesse caso, Machado (2016) vai nos dar uma indicação boa trazida da Indwelling de Polanyi:

Em uma incorporação com a consciência propiciada pela construção de canais de emergência, de mobilização do que se aprendeu, do que se sabe, é como se 
o saber passasse a residir na pessoa; em tal situação, ocorre o que Polanyi chama de indwelling. Com frequência, na escola, os conteúdos disciplinares são apresentados aos alunos e apreendidos por eles sem que venham efetivamente a residir neles, sem a ocorrência de qualquer indwelling. Avaliações são feitas e bons resultados são alcançados sem que o conhecimento torne-se um conhecimento pessoal dos alunos. Quando isso ocorre, por mais que os alunos pareçam saber, pouca ou nenhuma competência foi desenvolvida (2016, p. 39).

Nesse sentido, seria interessante observarmos a imagem do iceberg proposta por Polanyi. Ele nos mostra que a parte imersa na água é o nosso conhecimento tácito subsidiário e a parte visível, que está fora da água, é a parte que conseguimos explicitar. Se fizermos uma analogia com a água e o gelo, poderíamos entender melhor. Sabemos que a água tem uma densidade de $1,0 \mathrm{~g} / \mathrm{mL}$, do gelo de $0,9 \mathrm{~g} / \mathrm{mL}$, assim, podemos dizer que a diferença de densidade faz com que $10 \%$ do gelo fique fora da água. Nesse sentido, podemos afirmar que o mesmo pode ocorrer conosco. Quanto mais denso é o nosso entorno cultural, mais explicitamos o nosso conhecimento. Quanto mais ralo é o entorno cultural, menos explicitação acontece. Essa metáfora serve para nós educadores lembrarmos que ninguém, em nenhum contexto, consegue explicitar tudo o que sabe (densidade infinita não existe) e que a vida é, o tempo todo, esse equilíbrio do que está dentro com o que está fora. Veja a figura abaixo:

Figura 2 - Iceberg - objeto imerso em fraca e alta densidade
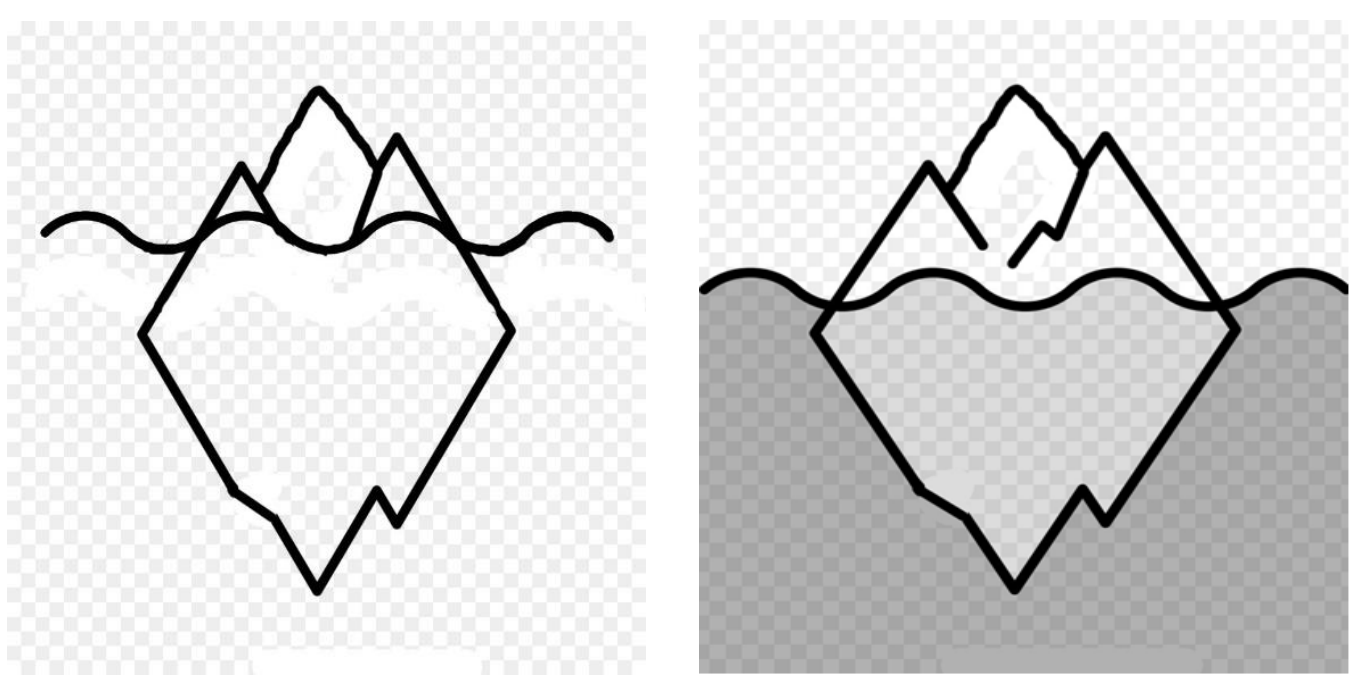

Fonte: da autora (2018)

Temos apenas que pensar nas dinâmicas pedagógicas que estamos usando para facilitar a explicitação do conhecimento subsidiário dos alunos. Há dinâmicas que são apenas troca de 
explicitações. O professor fala e o aluno copia. O professor prepara prova e o aluno faz, sem nenhuma interação. Isso é um sinal de grande pobreza. Há dinâmicas que fazem os alunos mastigarem, digerirem, engolirem e incorporarem o indwelling deles de forma inusitada, dinâmica e inesperada. Ajudar na explicitação do conhecimento de nossos alunos pode começar, por exemplo, na elaboração de uma prova associada a um contexto prático, interpretativo (a contextualização ajuda na explicitação). Se a prova perguntar somente o que aconteceu ou uma determinada data, estabelece apenas a troca de explícitos. Temos que dar o contexto para ajudar o aluno a expressar o que sabe.

A parte debaixo da água representa a cultura, os valores que o aluno já carrega subsidiariamente desde quando aprendeu tacitamente por meio do comportamento do outro, seus Indwelling etc. A escola, com seus programas, é o explícito. Mas nós aprendemos muito mais do que está no currículo. Captamos valores que não foram ensinados ou escritos. Um exemplo interessante (já mencionado anteriormente) para os professores é pegar os cadernos, tablets ou qualquer escrita dos alunos e verificar o que eles acham que ensinaram com o que os alunos disseram que eles ensinaram. Normalmente, vamos nos surpreender.

O interesse de qualquer educador deveria estar nesse nível mais profundo de expressão, das mais internas potencialidades de seus alunos, assim, a noção de um conhecimento do "repertoire" proposto por Pennycook (2016) talvez já seja uma tentativa de um entendimento mais consistente da expressão de nosso conhecer tácito:

O foco na dimensão corporal e emocional da interação intersubjetiva na 'experiência vivida da língua' (Spracherleben) (Busch 2015: 2) não toma línguas individuais como ponto de partida, mas concentra-se "na experiência subjetiva com seu repertório linguístico de multicamadas"(2015: 3). (...) A noção de um sujeito disperso, de linguagem e aprendizagem distribuídas através de um conjunto mais amplo de possibilidades que apenas o indivíduo e a sociedade, podem ser melhorados pensando-se em termos de assuntos e repertórios materialistas, vitalistas, encarnados e incorporados (PENNYCOOK, 2016, p. 30). (Tradução nossa.)

Desse modo, a formação escolar deve fornecer aos alunos a capacidade de expressão e de representação em esquemas de ação progressivamente mais complexos e significativos, promovendo a boa ação na colaboração de trabalhos solidários em equipe, projetando sempre o novo e vendo na visão dos problemas a possibilidade de valores e oportunidades.

Nesse caminho, podemos nos servir das artes como meio muito importante para os nossos objetivos de busca da subjetividade. São ferramentas excelentes de captação de substratos inatos. Clarice Lispector, no seu livro A Descoberta do Mundo (1999), por exemplo, chama-nos a atenção para a percepção das entrelinhas: 
Não entendo. Isso é tão vasto que ultrapassa qualquer entender. Entender é sempre limitado. Mas não entender pode não ter fronteiras. Sinto que sou muito mais completa quando não entendo. Não entender, do modo como falo, é um dom. Não entender, mas não como um simples de espírito. O bom é ser inteligente e não entender. É uma bênção estranha, como ter loucura sem ser doida. É um desinteresse manso, é uma doçura de burrice. Só que de vez em quando vem a inquietação: quero entender um pouco. Não demais: mas pelo menos entender que não entendo. (1999, p. 108)

Polanyi (2013) nos indica que com as nossas paixões intelectuais salvamos o conhecimento pessoal de ser meramente subjetivo, já que o compromisso intelectual tem intrinsicamente uma decisão responsável, submissão à verdade. Isso faz o foco deste trabalho se voltar para olhar os problemas causados pelo não uso do conhecimento tácito subsidiário com o exterior, focal. A título ilustrativo dos prejuízos desta separação, segue abaixo o trecho da biografia de Charles Darwin (2000), aos 30 anos de idade, mostrando o prejuízo da perda de subjetividade em sua vida:

Até os trinta anos de idade, poesia de muitos gêneros... deu-me grande prazer, e mesmo co ${ }^{4}$ mo escolar deliciei-me intensamente com Shakespeare, especialmente em suas peças históricas. Também disse que anteriormente quadros encantavam-me consideravelmente e a música muitíssimo. Mas agora, há muitos anos não consigo suportar a leitura de uma linha de poesia; experimentei ultimamente ler Shakespeare e achei-o tão intoleravelmente enfadonho a ponto de dar-me náuseas. Também perdi quase todo gosto por quadros ou música... Minha mente parece ter-se convertido em uma espécie de máquina para extrair leis gerais de grandes coleções de fatos, mas não posso conceber por que isso causou a atrofia apenas daquela parte do cérebro de que dependem gostos mais elevados... A perda dessas preferências é uma perda de felicidade e possivelmente danosa para o intelecto, e mais provavelmente para o caráter moral, por debilitar a parte emocional da nossa natureza. (DARWIN, 2000, p. 42). (Tradução nossa.)

Ainda segundo o referido autor, quando perdemos esse engajamento com nossas subjetividades mais intrínsecas ou subsidiárias, perdemos também com o todo universal,

\footnotetext{
4 "Up to the age of thirty," Charles Darwin wrote in his autobiography, "poetry of many kinds ... gave me great pleasure, and even as a schoolboy I took intense delight in Shakespeare, especially in the historical plays. I have also said that formerly pictures gave me considerable, and music very great delight. But now for many years I cannot endure to read a line of poetry; I have tried lately to read Shakespeare, and found it so intolerably dull that it nauseated me. I have also almost lost my taste for pictures or music... My mind seems to have become a kind of machine for grinding general laws out of large collections of facts, but why this should have caused the atrophy of that part of the brain alone, on which the higher tastes depend, I cannot conceive... The loss of these tastes is a loss of happiness, and may possibly be injurious to the intellect, and more probably to the moral character, by enfeebling the emotional part of our nature.
} 
verdadeiro, que nos sustenta como cidadãos livres e felizes. Assim, Polanyi (2013) nos conduz à esperança do conhecimento pessoal pela intenção universal:

É o ato de compromisso, com toda a sua estrutura completa, que salva o conhecimento pessoal de ser meramente subjetivo. O compromisso intelectual é uma decisão responsável, em submissão às interpelações fortes que, em boa consciência, eu concebo como sendo a verdade. É um ato de esperança, que se esforça por resolver uma obrigação dentro de uma situação pessoal pela qual não sou responsável e que, portanto, determina a minha vocação. Esta esperança e esta obrigação exprimem-se na intenção universal do conhecimento pessoal. (2013, p 68)

O processo educacional tende sempre a padronizar estruturas replicáveis - geralmente, com o intuito de controle. Assim, o conhecimento objetivo é muito bem-vindo. No entanto, se queremos professores motivados que promovam nos seus alunos projetos de vida interessantes e inteligentes para o bem-estar individual, escolar, familiar e social, devemos implementar, desde o ensino fundamental, políticas que incentivem o conhecimento pessoal nos alunos (sem renegar a tradição cultural), através de assimilação de novas experiências, buscando o que Polanyi (2013, p. 108) chama de "a marca de nossa personalidade inteligente".

Veja a Tabela 1, para melhor entendimento sobre os procedimentos da assimilação de uma experiência descrita pelo referido autor. 
Tabela 1 - TABELA DE UM QUADRO INTERPRETATIVO

PROCEDIMENTO OBJETIVO

\begin{tabular}{ll} 
PROCEDIMENTO OBJETIVO & PROCESSO DE ADAPTAÇÃO \\
& PARA UMA NOVA \\
& EXPERIÊNCIA \\
\hline - Um quadro interpretativo fixo; & - Adaptação deste quadro para \\
& incorporar as lições de uma \\
& nova experiência; \\
\hline - Forma impessoal com regras estritas; & - Sentido novo na articulação; \\
\hline - Atuação de rotina; & - Intervenção pessoal de quem \\
& fala para alterar regras da \\
& linguagem que se adaptem às \\
& novas ocasiões \\
\hline - Paradigma da contagem, os números (deixa o & - Ato heurístico e originalidade \\
quadro interpretativo) sem alterações significativas & \\
das frases poéticas; & \\
\hline - Estritamente reversível; & modificar as premissas \\
\hline - Processo formal - recapitula até as origens; & do nosso julgamento \\
\hline - Julgamento não pessoal. & (existência intelectual). \\
\hline & - É essencialmente \\
& irreversível; \\
\hline - Conversão às novas \\
premissas; \\
\hline
\end{tabular}

PROCESSO DE ADAPTAÇÃO

PARA UMA NOVA

- Adaptação deste quadro para

incorporar as lições de uma

(1)

âno

fala para alterar regras da

linguagem que se adaptem às

novas ocasiões

Fonte: da autora (2018)

Esse quadro quer mostrar as duas diferentes formas que temos de assimilação de uma experiência. A coluna da esquerda mostra o procedimento objetivo de todo o processo. A coluna da direita é o processo de adaptação desse quadro objetivo para as lições de uma nova experiência. Ele vai ganhar um sentido novo e preciso a cada nova articulação.

O interessante é que esse incentivo para fazer sempre essa assimilação de experiências não é algo egocêntrico: "Procuramos aqui a autossatisfação, apenas como uma parte daquilo que nos pode satisfazer no universo. A modificação da nossa identidade intelectual faz-se na esperança de um contacto mais próximo com a realidade”. (POLANYI, 2013, p. 109) 
É notória a consciência do nosso poder subsidiário. Mas, por que confiamos as nossas vidas basicamente à orientação objetiva dos nossos pensamentos, deixando a racionalidade preponderar em nossa realidade? No capítulo a seguir, tentaremos analisar as dimensões emocionais envolvidas no processo de bloqueios às nossas intervenções pessoais, especialmente no que tange ao aprendizado de línguas estrangeiras. 


\section{AS DIMENSÕES EMOCIONAIS E OS BLOQUEIOS NA APRENDIZAGEM DE LÍNGUAS ESTRANGEIRAS}

Considerando os subsídios fornecidos pela perspectiva teórica de Polanyi, podemos construir novas possibilidades articulatórias que estimulem o processo de Indwelling, tendo como base a seguinte maneira de analisar o processo psicológico:

Reconhecer alguém como uma pessoa sã é estabelecer uma relação recíproca
com ela pelo contraste. Pela virtude de nossa própria arte de compreensão,
experimentamos as faculdades similares de outra pessoa, com a presença da
mente desta pessoa. Nossa capacidade de conhecer as coisas de maneira focal
ou subsidiária é decisiva aqui. A mente não é aquele agregado de
manifestações focais conhecidas, mas é que focalizamos nossa atenção ao
mesmo tempo em que estamos subsidiariamente conscientes de suas
manifestações. Essa é a maneira pela qual reconhecemos o julgamento de uma
pessoa e compartilhamos também outras formas de sua consciência. Essa
maneira de conhecer uma pessoa qualifica o indivíduo plenamente para as
funções de uma mente na posição I (mente (do neurologista)) de um sistema
tripartido controlado por uma mente; enquanto aquele agregado de
manifestações focais conhecidas não o qualifica para essas funções
(POLANYI, 1958, p. 263). (Tradução nossa.)

Entendemos que a teoria de Polanyi constrói uma nova ontologia da mente. Isto é, afastando-se da teoria objetivista, o autor trabalha com a noção de que o conhecedor não deve se manter exilado dos próprios processos mentais. Para aceitar o indeterminismo do conhecimento, temos de acreditar que a pessoa desenvolve sua inteligência de acordo com seu próprio julgamento. Nesse sentido, se aplicarmos essa noção às pessoas, trabalharemos diretamente com aspectos da sociologia, na medida em que o crescimento do pensamento é reconhecido como uma força independente. Isto é, nossa mente não é um agregado de manifestações externas (focais), mas sobretudo um "compartilhar" com a mente do outro. Como Polanyi menciona acima: "pela virtude de nossa própria arte de compreensão, experimentamos as faculdades similares de uma outra pessoa".

Em primeiro lugar, temos que considerar a tradição cultural como base ou como ponto de partida de apoio ao modo subsidiário de conhecimento. Nesse sentido, já podemos notar que, para Polanyi, o conhecimento não pode ser obtido ou processado sem uma continuidade cultural, numa confiança mestre-aprendiz, que se verifica pelo exemplo abaixo:

Aprender pelo exemplo é submeter-se à autoridade. Você segue seu mestre por confiança em sua maneira de ver as coisas mesmo quando não pode analisar e explicar sua eficácia em detalhes. Observando o mestre e emulando 
seus esforços em presença de seu exemplo, o aprendiz capta inconscientemente as regras da arte, incluindo aquelas não conhecidas pelo próprio mestre. Essas regras ocultas podem ser assimiladas por uma pessoa que se submete a imitar outra, sem muita crítica. Uma sociedade que pretenda preservar um fundo de conhecimento pessoal deve submeter-se à tradição (POLANYI, 2013 apud SAIANI, 2004, p. 86).

Saiani (2004) também destaca:

Polanyi comenta que a transmissão de bens e valores culturais (que ele chama de "artefatos intelectuais") ocorre por um processo de comunicação que flui dos adultos para as crianças. É aqui que podemos incluir a escola: sendo ela uma agência de transmissão dos valores culturais, e sendo eles gerados por paixões intelectuais, é tarefa da escola muito mais despertar e fomentar tais paixões do que transmitir informações e procedimentos. Penso que esse simples objetivo empurra para o segundo plano discussões, por certo apaixonadas, sobre currículo e disciplinas, que de nada valerão se não forem animadas pelo compromisso (commitment) de alunos e professores (p. 86).

Delineiam-se, assim possibilidades de se criar oportunidades para o desenvolvimento de paixões intelectuais e o comprometimento com elas. Uma escola que tenha como principal finalidade a consideração de aspectos tácitos subsidiários, em conexão com conhecimentos explícitos, poderá possibilitar projetos pessoais engajados por parte dos alunos (promovidos por professores conscientes), em prol de uma educação realmente eficaz, por estar em compasso com a real natureza do aluno.

Mas, quais seriam os fatores impeditivos de desempenhos e desenvolvimento de nossas capacidades tácitas e explícitas, que parecem ser aspectos naturais em nossa existência? Talvez, a melhor maneira de começar o entendimento seja colocar nossas oposições psíquicas ao processo natural de (se) conhecer.

Sobre essa questão, na obra A Libertação pelo Conhecimento, Norberto Keppe (2001) afirma que "o mais importante é o conhecimento daquilo que impede o próprio conhecimento" (p. 5). Ou seja, o pesquisador considera em sua investigação os fatores que o impedem de usufruir de suas possibilidades de conhecimentos subsidiários, principalmente aqueles emocionais.

Alguns estudos atuais, como o de Damásio, no livro O Erro de Descartes (2001), apontam uma nova visão sobre a influência das emoções em nossas vidas. Mesmo sendo difíceis de serem analisadas, por sua natureza subjetiva, é de extrema importância reconhecermos sua presença nos processos cognitivos, bem como buscarmos novos parâmetros de pesquisas e análise para os bloqueios no campo de ensino e aprendizagem - no caso deste trabalho, os 
bloqueios no processo de ensino/aprendizagem de línguas estrangeiras. Professores, monitores, coordenadores, diretores, pais e alunos estão todos envolvidos em tramas emocionais de toda sorte e, na maior parte das vezes, desprovidos de qualquer entendimento para identificá-las e tratar delas.

No mais, os estudos atuais dessa temática tendem a fazer análises racionais das emoções, tentando enquadrá-las em regras objetivas, para domesticá-las e torná-las palatáveis ao público. Isso é um prejuízo inestimável à constituição intuitiva e criativa de professores e alunos. Zembylas (2006) percebe essa tentativa quando enuncia que:

As emoções são entendidas como o tipo de experiência positiva ou negativa de um indivíduo e são construídas através da interação de ambas as condições psicológico-fisiológicas e padrões socioculturais. (...)

Emocionologia (emocionology) é outro termo desenvolvido no campo da história das emoções, que se refere à cultura emocional ou às regras emocionais construídas nessa cultura - isto é, as regras ou normas pelas quais as pessoas devem moldar sua cultura, expressões emocionais e responder às expressões dos outros (pp. 251-252). (Tradução nossa.)

Por outro lado, Prosch (1986) explora a visão de Polanyi, ao criticar as teorias mecânicas do conhecimento.

Ele parecia estar insinuando que tendemos, sob a influência de várias teorias mecânicas do conhecimento, a considerar as pessoas apenas como conjuntos complexos de estímulos e respostas - ou de equilíbrios automaticamente alcançados - e, portanto, como entidades cujo pensamento, sendo apenas respostas condicionadas ou equilíbrios, de qualquer forma, pode e deve ser condicionado ou equilibrado "adequadamente", isto é, uma lavagem cerebral (pp. 65-66). (Tradução nossa.)

Isso sem contar com o fato de já existir a commodification of emotion, recentemente expandida no campo da educação, por meio de livros como o de Daniel Goleman sobre a Inteligência Emocional, o qual realça e vende a ideia de promoção de seres humanos melhores e mais produtivos. Assim, é importante analisarmos alguns aspectos impeditivos da expansão subjetiva e emotiva de cada indivíduo, no processo de articulação entre o conhecimento tácito subsidiário e o conhecimento explícito, sem pretender classificar metodologicamente para uso escolar de forma mecânica, já que desse modo estaremos voltando aos padrões racionais e cartesianos de conhecimento.

$\mathrm{Na}$ tentativa de uma abordagem mais analítica desses processos emocionais, vamos começar com algumas considerações de Polanyi (1986): 
Cannizoro e Braid fizeram descobertas conceituais que se consolidaram pela melhoria da linguagem; A excelente compreensão deles sobre um assunto permite que eles falem com mais propriedade. Tal inovação linguística está ligada à formação de novas concepções, da mesma forma que a aprendizagem de uma nova língua estabelecida está vinculada à aquisição de concepções atuais de seu assunto. Como no caso do verbalismo infantil, as confusões das quais vimos exemplos nas ciências naturais consistem em uma deficiência de controle intelectual, que causa inquietação e é remediável pela reforma conceitual e linguística (p. 108). (Tradução nossa.)

O autor (1986) continua dizendo sobre o problemático estado da mente:

Devo divagar aqui brevemente para considerar mais de perto o processo pelo qual a confusão é eliminada nesses diferentes casos e em outros relacionados a eles. A separação entre o texto e o seu significado, seja na criança ou no cientista, é o sinal de um estado mental problemático. A sede dessa confusão é sempre conceitual. Há evidências independentes, do estudo de animais, que a confusão pode surgir no nível puramente articulado. A confusão humana pode ser verbal, no sentido de que não poderia ser produzida sem o uso da linguagem (p. 108). (Tradução nossa.)

Ancorados em Polanyi, poderíamos concluir, portanto, que a incorporação (Indwelling) do conhecimento pode ficar prejudicada pela separação entre o texto e o significado, criando um estado mental problemático, causando confusão e estados emocionais indesejados. Se um professor, por exemplo, der uma matéria sem contexto ou sem relação com a realidade, pode, eventualmente, estar privando seus alunos de um engajamento com seus aspectos subsidiários, que são componentes importantes para o desenvolvimento deles.

Assim, consideramos pertinente recorrermos à transdisciplinaridade, buscando nos mares da psicanálise autores que poderão nos dar bases para o entendimento dos fatores impeditivos do conhecimento explícito, já que no campo da Linguística Aplicada o tema é tratado muito timidamente. Aragão (2008) menciona:

[...] que a grande ironia é que a emoção poderia terminar provando ser a força mais influente na aquisição de linguagem, mas as variáveis afetivas constituem a área que os pesquisadores de aquisição de segunda língua entendem menos. Scovel (2000: 127) vai além ao afirmar que embora o conceito de ansiedade seja o mais discutido na área, ele pode ser o mais mal compreendido. Isto pode ser devido ao fato de o conceito ter um sentido distinto para o público do que ele tem para os pesquisadores. MacIntyre (1999: 24) em comum acordo com Scovel (2000) argumenta ainda que o cenário é confuso entre os pesquisadores que tendem a compreender o conceito e seus efeitos de maneira bastante distinta (ARAGÃO, p. 2659). 
Portanto, trabalhar com o fator emocional não é um objetivo simples. Muitos podem pensar, por exemplo, que lidar com o emocional seria apenas segurar uma emoção indesejada em sala de aula, como a raiva. Zembylas (2006, p.254), nos apresenta um exemplo de uma professora que teve o intuito de modificar a maneira de sentir, ou quais emoções mostrar, a fim de esconder sua raiva contra alguém, porque a ira tem se tornado cada vez mais infantil e inaceitável no local de trabalho. Esse exemplo mostra a necessidade de uma conscientização da problemática e não de esconder os sintomas. Ela tinha raiva, mas não queria mostrar a ninguém, porque não é socialmente aceitável, mas o ideal é que ela visse o problema e tratasse dele, e não que o escondesse.

Pela dificuldade de sistematização dos fenômenos emocionais dentro de um padrão racional, fica difícil o entendimento de como seria trabalhar as emoções em sala de aula. $\mathrm{O}$ cenário é bem confuso, tanto para os pesquisadores quanto para as linhas de estudo. Portanto, a visão de Aragão (2007) é bem sugestiva.

Arnold e Brown (1999) argumentam que o processo de aprendizagem deveria ser apoiado numa visão mais holística e humanista, em que emoção e cognição andassem lado a lado, já que estudos neurobiológicos têm demonstrado que as emoções fazem parte da razão e que não há processos mentais sem processos emocionais, uma vez que estes são parceiros no funcionamento do sistema nervoso. Para os autores, uma compreensão ampla da dimensão afetiva no ensino e na aprendizagem de línguas é importante por duas razões. Em primeiro lugar, uma atenção para os aspectos afetivos pode levar-nos a um ensino mais efetivo, ao propiciar que os alunos superem emoções negativas que inibem sua aprendizagem e fomentar emoções que facilitem o processo. Em segundo lugar, como consequência de uma supervalorização do cognitivo, do linguístico e do racional, nós nos tornamos analfabetos emocionais. $\mathrm{O}$ ensino pode ir além do objetivo da aprendizagem da língua, mas um espaço de educação do afeto e da ética pode levar os alunos a uma maior responsabilidade com a sociedade. A informação pode coexistir com a formação. Arnold e Brown (1999) colocam a dimensão afetiva em paralelo às abordagens humanistas no ensino e na aprendizagem de segundas línguas. (ARAGÃO 2007, p. 2656).

Já Polanyi (2013) apresenta uma ideia de rejeição que fazemos de nossa apreensão subsidiária do conhecimento pelo medo. Um artista com medo vai inibir suas possibilidades subsidiárias:

O tipo de confusão devido ao facto da atenção focal estar dirigida para os elementos subsidiários de uma ação é muitas vezes conhecida como autoconsciência. Uma forma séria e por vezes incurável, é o "medo do palco", que parece consistir numa fixação ansiosa da nossa atenção sobre a próxima palavra - ou nota, ou gesto - que uma pessoa precisa de recordar. Isso destrói todo o sentido de contexto, o único capaz de evocar suavemente as sequências adequadas de palavras, notas ou gestos. O medo dos palcos é eliminado, e a fluência recuperada, procurando conformar a nossa mente para o futuro e 
deixando-a operar com uma visão clara da atividade compreensiva em que, em primeiro lugar, se está interessado.

Uma vez mais, os particulares de uma competência aparecem aqui como não especificáveis, mas não no sentido de ignorância. Neste caso, temos certezas sobre os detalhes da nossa performance, e a não especificabilidade tem por consequência paralisar a performance se, entretanto, focarmos a nossa atenção nesses detalhes. Podemos descrever essa performance como sendo logicamente não especificável, pois podemos mostrar que, num certo sentido, as especificações dos particulares estariam em contradição lógica com o que está implícito na performance ou no contexto em questão (p.58).

Mas, o que nos faz sair desta realidade unificada do todo tácito e privilegiar os particulares? Quais os métodos ineficazes que usamos para particularizar o nosso foco, rompendo a formação de significados, bloqueando nossa aprendizagem e criando problemas emocionais de toda espécie?

Polanyi (2013) nos mostra os elementos iniciais para uma possível resposta, explicitando a diferença que sentimos entre o que faz parte do nosso próprio corpo e as coisas que lhe são externas:

Habitualmente tomamos por garantido que as nossas mãos e os nossos pés são membros do nosso corpo, e não objetos externos, e só nos apercebemos deste pressuposto quando ele é perturbado por uma doença. Há certos pacientes psicóticos que não sentem que uma parte do corpo lhes pertence. Têm todas as sensações normais transmitidas pelos seus membros de ambos os lados, mas não os identificam consigo, como os membros de onde essas mensagens tiveram origem; alguns sentem, por exemplo, o braço direito ou a perna direita como objetos externos ao saírem de um banho pode acontecer que se esqueçam de secar esses membros não reconhecidos. A nossa avaliação da externalidade dos objetos fora do nosso corpo, por contraposição com as partes do nosso próprio corpo, reside na nossa apreensão subsidiária dos processos dentro do nosso corpo (p.61).

No caso citado, certos psicóticos não fazem a apreensão subsidiária e focal, produzindo conhecimento pessoal diferenciado por causa da psicose. Deste modo, a doença psicológica neurose ou psicose pode ser considerada como um fator impeditivo de nossas apreensões (Indwelling).

Vale a pena mencionar também a importância do afeto no momento de apreensão de significação, como apresenta Henri Paul Wallon (1989) na sua teoria da emoção e do caráter. O teórico destaca a importância da afetividade como papel fundamental no desenvolvimento da personalidade, pois, para ele, o afeto é o primeiro domínio funcional percorrido pela criança. $\mathrm{O}$ recém-nascido e o infante, no seu primeiro ano de vida, utilizam gestos e expressões carregadas de significados afetivos, anteriores à inteligência (WALLON, 1989; ARAGÃO, 2017). 
O referido autor propõe o estudo da pessoa completa: tanto em relação a seu caráter cognitivo quanto ao afetivo e motor. Assim, a cognição é importante, mas não mais que a afetividade ou a motricidade. Cognição e afetividade são duas faces de uma mesma pessoa. Assim, a posição teórica de Wallon se consolidou contrária à compreensão do humano de forma fragmentada.

Desse modo, podemos afirmar que assim como os problemas psicológicos funcionam como fatores impeditivos à aprendizagem, o componente afetivo funciona como fator potencializador de "Indwelling". Nessa perspectiva, consideramos as emoções positivas, como afetividade e humildade como base, atuando em prol da competência emocional, que é a fonte mais importante de desenvolvimento do indivíduo. As emoções negativas, como o "medo" e a "raiva", desencadeiam automaticamente uma reação hormonal no organismo, reação que se processa num nível frequentemente fora da percepção do indivíduo. Segundo o professor Hans Hoff (PACHECO, 2001), da Universidade de Viena, Áustria, um desequilíbrio hormonal causado por uma emoção atua em nível cerebral como uma "úlcera" nas células nervosas. Nesse sentido, uma emoção negativa consciente ou inconsciente pode provocar um bloqueio mental no indivíduo sem que o sujeito tenha percepção de tal processo.

Podemos afirmar que diversos bloqueios mentais, ocasionados pelas emoções, são reflexos das histórias de vida de cada pessoa. Logo, é impossível não perceber que a forma como cada aluno lida com a história própria de vida pode afetar o desempenho acadêmico. No caso do ensino de línguas estrangeiras, por exemplo, é muito comum encontrarmos alunos angustiados e temerosos quando pensam em falar com um estrangeiro, mesmo que tenham uma boa proficiência no idioma. Obviamente, esse aspecto emocional é um impeditivo a um bom desempenho profissional. A figura do estrangeiro é um fator inibidor para muitos falantes de línguas estrangeiras, especialmente no Brasil, em que o índice de proficiência do inglês é muito baixo: $40^{\circ}$ lugar no ranking mundial (MORENO, 2015).

A Linguística Aplicada, em seus novos estudos do inglês como Língua Franca, remetenos a pesquisas modernas de compreensão desse idioma como um veículo mundial de comunicação e não mais como um modelo estereotipado de uma língua monolítica nativa e normativa, que todos devem procurar imitar com sotaques perfeitos. Tais estudos estão sendo desenvolvidos mundialmente para que os novos falantes não precisem se comportar como indivíduos inferiores e em desvantagens culturais, sociais e profissionais por não falarem um inglês castiço (YASUKATA, 2009). Na medida em que esses estudos atinjam um maior número de pessoas em nossa sociedade, através de uma socioculturalidade global mais híbrida, de acomodação e de compreensão, acredita-se que muitos alunos terão menos medo de enfrentar 
uma reunião com falantes nativos, pelo fato de poderem expressar suas identidades, suas sociedades e suas culturas mais livremente. No entanto, nosso foco se concentra mais propriamente nos aspectos interiores impeditivos de significação.

Um outro aspecto muito angustiante e de forte peso emocional para os alunos é o processo avaliativo, pois ele geralmente desencadeia sentimento de comparação e avaliação julgadora, o que pode limitar o desempenho, especialmente oral dos participantes (ARAGÃO, 2007). Nos estudos atuais da Linguística Aplicada, uma nova orientação crítico-reflexiva trabalha a investigação de como a linguagem opera no mundo social contemporâneo multifacetado e de múltiplas vozes. Com isso, novas formas de ensino têm sido propostas e novas formas avaliativas mais condizentes têm sido criadas a partir dos novos multiletramentos atuais (DUBOC, 2015). Tais ações podem operar como fatores tranquilizantes para muitos fatores emocionais anteriores.

É importante considerar que os fatores emocionais podem atrapalhar o processo de ensino/aprendizagem assim como o processo de aprender pode gerar tensões emocionais - eles estão intrinsecamente ligados. Por exemplo, Roeser e Eccles (2000, p. 140) discutem a tensão emocional gerada pelos sentimentos.

Crianças que vão mal na escola e atribuem essas dificuldades a um sentido fixo de incompetência pessoal passam por sentimentos de vergonha, insegurança, baixa estima e alienação do aprendizado (por exemplo, sofrimento interiorizado, ver Dweck \& Wortman, 1982). Alternativamente, as crianças que atribuem problemas acadêmicos à influência de pessoas hostis ou a falta de apoio desenvolvem sentimentos de raiva, alienação acadêmica e hostilidade em relação aos outros.

As avaliações das crianças sobre a dificuldade acadêmica também podem contribuir indiretamente para a saúde mental por meio do impacto de tais avaliações no desenvolvimento de autopercepções de competência acadêmica, valor acadêmico e crenças sobre o apoio relativo de outras pessoas em situações de aprendizagem. Crenças de competência, valores e sentimentos de apoio estão associados a sentimentos de estima, interesse e pertencimento, enquanto sentimentos de incompetência, baixo valor e baixo apoio estão associados a sentimentos de vergonha e dúvida, desinteresse e tédio e isolamento ou vitimização (AMES, 1992; ECCLES et al., 1998; ROESER, ECCLES, \& STROBEL, 1998). (Tradução nossa.)

A Figura 3 mostra os processos psicológicos que interligam a tensão emocional aos problemas acadêmicos em um círculo vicioso. 


\section{Figura 3 - Processos Psicológicos Ligados a Problemas Acadêmicos e Tensão Emocional}

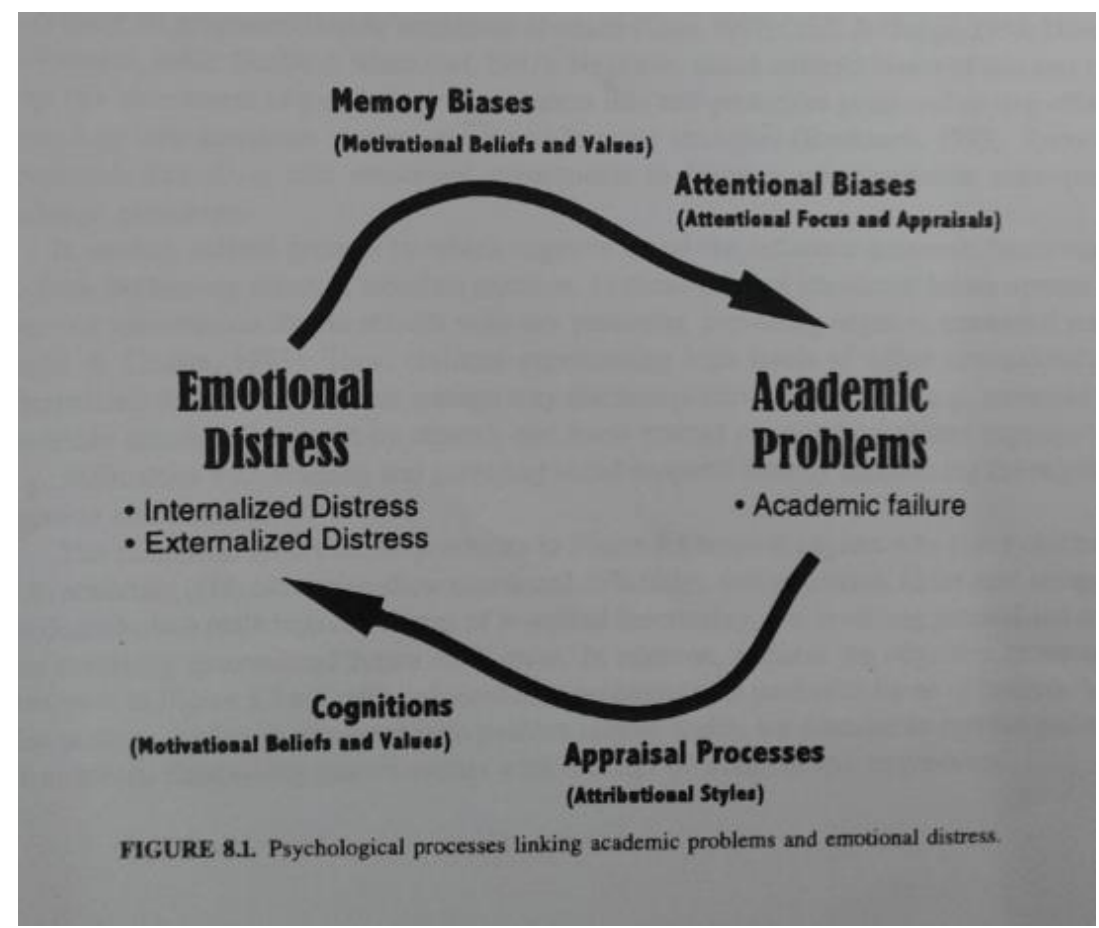

Fonte: Roeser e Eccles (2000, p. 139)

O esquema esclarece a influência dos aspectos emocionais nos fracassos acadêmicos e, por sua vez, o prejuízo emocional de tais fracassos, mostrando a necessidade de mais estudos a respeito do círculo vicioso.

Duboc (2015), por exemplo, incita-nos a pensar a ressignificação da prática pedagógica a partir de "brechas pedagógicas em uma atitude curricular", numa perspectiva crítica da educação. "É uma atitude transformadora que ocorre nas brechas de sala de aula, ou seja, naqueles muitos momentos frutíferos que emergem dos dizeres ou fazeres dos alunos [...]” (p.08). Inúmeras emoções acontecem no universo escolar, de variada natureza. Assim, podemos aproveitar um conflito, uma discórdia, um gesto afetivo ou qualquer percepção interessante para levar ao grupo e discutir. $\mathrm{O}$ aspecto intuitivo pode funcionar de maneira muito interessante. Geralmente, muitas surpresas positivas acontecem.

De maneira análoga, se o educador tiver um mínimo de conhecimento e entendimento do processo psicológico consciente ou inconsciente, poderá aproveitar as ocasiões em que as manifestações emocionais ocorrem, para uma intervenção de consciência para o benefício de um aluno específico e de todo o grupo envolvido por identificação (AVELINO; CAMPOS, 2011). 
As emoções estão na base de sucessos e insucessos dos desempenhos dos alunos, mas como a atenção sempre foi voltada para os indicadores racionais de rendimento, muito tempo de estudo foi perdido nessa área de atuação. Talvez, agora seja o momento histórico ideal para se estudar mais profundamente o assunto, de forma a abarcar o maior número de significados possíveis, na tentativa de responder ao complexo processo emocional que influencia a aprendizagem.

Podemos dizer que a dimensão afetiva poderia funcionar como um elemento facilitador de Indwellings, já que o indivíduo não estaria colocando barreiras emocionais negativas ao seu conhecimento subsidiário. Como funcionaria o processo de oposição ao conhecimento natural inato? O que faria um indivíduo ficar petrificado ao ter que falar inglês com um estrangeiro e nesse momento de pânico fragmentar o seu campo afetivo e fazer um bloqueio ao campo cognitivo natural, além do fator físico?

Na tentativa de elucidar melhor o assunto, analisaremos a ideia de Alfred Adler (1977), com seu Complexo de Inferioridade, e a Teomania, de N. Keppe (1980), no sentido de examinar novas formas de discursos contemporâneos sobre a constituição das emoções, numa visão mais crítica das noções de arrogância, superioridade e teomania. Ambas as teorias trazem elementos para entender o impedimento dos nossos "saberes tácitos", através de bloqueios oriundos de emoções negativas, as quais perturbam o relacionamento com o mundo a nossa volta.

\subsection{Alfred Adler e o Complexo de Inferioridade, e Norberto Keppe e a Teomania}

Alfred Adler (1870-1937) era austríaco e colaborador muito estimado por Freud. Separou-se do movimento psicanalítico e criou seu próprio grupo de psicologia-individual em Viena. Dedicou-se a uma intensa atividade nos estudos psicanalíticos, com ótimos efeitos, visto que conseguiu introduzir as suas teorias em escolas, jardins de infância e no tratamento dos doentes. Suas noções de Complexo de Inferioridade e de protesto viril tornaram-se muito famosas.

Adler inicia seu trabalho fundamentando-se na observação de um problema orgânico sendo compensado, seja pela utilização de outro órgão, seja por um esforço particular imposto ao órgão deficiente. É possível reportar-se a Demóstenes (384 a.C.), como exemplo, o qual, apesar de ser gago, tornou-se o maior dos oradores gregos. A inferioridade orgânica também suscita reações psíquicas sob a forma de fantasias compensatórias. Em um outro momento, Adler ampliou a noção de inferioridade, assegurando que esse sentimento existe em todas as pessoas e que possui sua fonte na infância, no momento em que o indivíduo se sente pequeno 
e fraco diante do adulto, sentimento de inferioridade favorecido pela atitude minimizante dos pais.

Todavia, o sentimento de autovalorização na criança é muito forte, ela luta e se defende contra o sentimento de inferioridade. $\mathrm{O}$ sentir-se inferior pode agir como um estimulante, uma força positiva para o futuro desenvolvimento da criança. Mas, para isso, ela precisa ter um certo desejo de poder, que é praticamente idêntico à forma específica do instinto de autoconservação. Seria livrar-se do inevitável sentimento de inferioridade (autoavaliação), tornando-se o motor dinâmico para o desenvolvimento da personalidade humana na psicologia adleriana.

Uma vez incentivados e estimulados os sentimentos de autovalorização da criança, ela procura meios e caminhos especiais para conseguir reconhecimento e aprovação, com o fim de compensar o seu sentimento de inferioridade. Segundo Adler, o sentimento de inferioridade faz nascer um desejo compensatório de superioridade, de dominação e de poder, que pode conduzir a alguma forma de sucesso pessoal; ou, traduzir-se em desejos irrealistas e na busca de objetivos irrealizáveis, que caracterizam a neurose. Se a criança sentir grande dificuldade de impor ao mundo exterior seu verdadeiro ego, seu desejo natural de poder transformar-se-á em obsessão. Isto se observa nos casos de compensação. O desejo de superioridade, então, torna-se doentio.

Quanto mais a criança se sentir inferiorizada, tanto mais procurará incentivar o seu sentimento de autovalorização, tornando-se significante tudo o que lhe puder proporcionar importância. Se os seus sentimentos de inferioridade são muito fortes, pode acontecer de ela não perceber mais os seus limites e, em lugar de se orientar pelo justo, certo, real e necessário, vai procurar apenas o que lhe poderia proporcionar a atenção, elogios e uma importância social; logo, seu objetivo final tornar-se-á fictício. Como meio para se fazer salientar, a criança usa o seu instinto de autoconservação ou se revolta (protesto viril). Enfim, faz tudo o que pode para chamar a atenção, tanto no sentido da obstinação, como na obediência exagerada, na diminuição dos outros etc.

O único modo de proteger a criança contra os excessivos sentimentos de inferioridade (e, consequentemente, contra o aumento dos seus sentimentos de autovalorização e os objetivos finais fictícios) consiste em fortificar o seu sentimento de comunidade - e aqui encontramos as famosas tendências social-pedagógicas de Alfred Adler. A criança tem que achar um meio termo entre as necessidades de autovalorização (cada exagero impossibilita o sentimento de comunidade, resultando num desenvolvimento defeituoso) e o sentimento de comunidade (o exagero leva à repressão da autovalorização, vingando-se, mais tarde, em forma de sintomas, neuroses etc.). Condições sociais desfavoráveis como pobreza, abandono, extrema riqueza, fartura, posição desfavorável entre os irmãos, na família, ou educação errônea como severidade 
exagerada ou permissividade, pais muito intrometidos ou sem afeto, pais nervosos ou vaidosos entre outros fatores serão a mola propulsora de compensações para o problema.

Em geral, podemos dizer que o maior campo de aplicação da individual-psicologia encontra-se, sem dúvida, no setor pedagógico ou, então, na psicoterapia infantil. Se o aspecto geral da psicanálise de S. Freud era causal, determinado, isto é, retrospectivo, procurando as causas de um distúrbio psicopatológico, o processo da individual-psicologia é finaldeterminado. Adler não pergunta, por exemplo, por que uma criança está mentindo, mas, com que finalidade? Para ele, tudo o que uma pessoa faz tem um objetivo final, e esse objetivo pode ser consciente ou inconsciente.

Adler considera também as neuroses em termos de um aspecto finalista, quer dizer, ele próprio se interroga, frente ao neurótico, qual o objetivo que ele poderá alcançar através de tal comportamento? Na maioria dos casos, o objetivo final é o de superioridade, que ele não tem coragem de procurar pelos caminhos retos e comuns da sociedade. E a doença, na qual se refugia da realidade, serve como desculpa para tudo o que omitir ou fizer mal feito. Assim, a neurose se torna uma forma de existência social, um esforço do indivíduo para se firmar, por meio de arranjos e artifícios que lhe assegurem licença para fugir da sua responsabilidade pessoal. O sintoma neurótico representa a fuga de uma decisão, devido a um sentimento de insegurança interno; uma capitulação face aos seus deveres, um certo ato de covardia. A neurose se lhe impõe como uma doença que deve ser tratada e mimada; uma debilidade que os outros deveriam respeitar.

Adler procura, na sua psicoterapia, não fazer primeiramente o sintoma desaparecer, mas mudar completamente o estilo e plano de vida. Ele evita mostrar interesse pessoal na melhora do doente, para não o levar a se "punir", sempre e quando precisar, piorando nos seus sintomas. O paciente tem que reconhecer que é do seu próprio interesse a sua cura e que toda a responsabilidade é sua, porque somente o indivíduo capaz de assumir os seus deveres na vida está a caminho de uma cura genuína. Para a reeducação posterior, vale o mesmo princípio básico (como em todo o processo de educação tipicamente adleriana): educar é encorajar!

A base do conceito de Adler consiste na passagem de um sentimento de inferioridade para um sentimento de poder e domínio. Quando o sentimento de poderio for muito intenso, ele é capaz de comprometer o desenvolvimento positivo da criança. E se for moderado servirá de impulso para realizações positivas e superações de obstáculos. Assim Adler (1977) destaca:

É errado pensar que uma mente saudável se encontre sempre em um corpo saudável. Uma criança doente pode ter uma psique equilibrada se enfrentar a 
vida com coragem, apesar de suas deficiências físicas. Por outro lado, ele pode estar em boa saúde, mas psicologicamente perturbado se, por uma combinação de circunstâncias desagradáveis, ele for levado a interpretar mal suas faculdades mentais. $\mathrm{O}$ fracasso numa dada tarefa pode induzi-lo a acreditar em sua própria incapacidade. É por isso que esse tipo de criança é muito sensível às dificuldades e considera cada obstáculo como uma confirmação de sua impotência (p. 54) (Tradução nossa.)

De certa maneira, podemos ver a compensação neurótica provocando fortes crises emocionais em alunos. Noto especialmente em alunos do ensino médio tal postura de poder e domínio constantes numa tentativa de compensação neurótica.

Logicamente, a manifestação das emoções no ambiente escolar vai depender também do tipo de autoridade ou sistema de verdades (ética) que a escola segue. Alunos e professores seguem mais ou menos uma regra emocional estabelecida ou permitida pelo ambiente, pois ninguém quer se tornar objeto de exclusão ao se isolar do conjunto de regras estabelecidas no contexto emocional.

Vemos também que as práticas de subjetivação estão fundamentalmente ligadas a um projeto de identidade em que as emoções estão intricadamente ligadas com alguma forma de poder. Portanto, o projeto de identidade está constitutivamente ligado à persuasão do mundo emocional da pessoa e da sua relação interna com os outros.

Podemos compreender como a ideia de conhecimento tácito de Polanyi vai ser importante, já que a subjetivação de uma pessoa vai depender do grau de relações que ela estabelece com seu entorno. Se o grau de arrogância do indivíduo for grande, vai tender a se isolar, vai impedir o resgate de seus conhecimentos tácitos e consequentemente vai quebrar a dialética com os seus conhecimentos implícitos e explícitos. Assim, a arrogância e o desejo de poder são fatores de peso para a desorganização emocional do indivíduo porque vão servir de barreira a suas Indwellings.

O desejo extremado de poder (megalomania) é o que N. Keppe aborda na identificação inicial do processo emocional negativo presente em muitos indivíduos e que causa transtornos no processo de aprendizagem.

Keppe afirma ter percebido que o nervosismo, a neurose, a psicose e doenças físicas são causadas primordialmente por uma batalha que levamos a cabo contra a verdade, a beleza e a bondade, oriunda dessa base de cunho megalômano no indivíduo, necessitando de um certo grau de humildade para retornar ao contato com o próprio interior bom (sanidade).

Afirma que esse fator de megalomania mais forte que o advindo do complexo de inferioridade de Adler seria o que chamou de teomania. Neste sentido, assegura que baseou seu conceito de teomania (mania de querer ser um Deus), com os derivativos: megalomania, 
narcisismo e egocentrismo, nas descobertas de Emil Kräepelin (1865 - 1926), Wolfgang Kohler (1887 - 1967) e Eugen Bleuler (1898 - 1927), que situaram a problemática central do homem em questões de megalomania.

Tendo formação inicial psicopedagógica e psicológica, efetuada na Pontifícia Universidade Católica, situada à Rua Monte Alegre, no bairro de Perdizes (São Paulo - Capital), de 1952 a 1955, sob a orientação de Enzo Azzi (1921 - 1985), psicólogo e pedagogo italiano, Keppe percebeu como esse problema de megalomania influenciava na questão da aprendizagem. (KEPPE, 1988).

Segundo ele, a língua inglesa tem uma palavra para definir entendimento, que explica bem o processo de aprendizagem: understanding (under = embaixo; standing = permanecer). Ou seja, para aprender, o aluno precisa permanecer em uma posição inferior, saber que sua escola e seu professor estão acima dele, em tempo de vida, experiência, conhecimentos etc., isto é, o estudante precisa ter humildade (vocábulo de sentido oposto a megalomania). Quanto mais arrogante for, mais se colocará acima do professor e da escola, achando que sabe mais que seu mestre, impedindo-se assim de assimilar conhecimentos.

Keppe inclui Adler em sua escola psicanalítica, mas não só. O primeiro autor psicanalítico que contatou foi Igor Caruso, presidente do Círculo Vienense de Psicologia Profunda, que, após conhecer o seu trabalho o convidou a ir a Viena estudar a Psicologia Profunda (Tiefenpsychologie).

Na época (1958) Keppe trabalhava no Hospital das Clínicas da Faculdade de Medicina da Universidade de São Paulo em diversos trabalhos de aplicação da Psicologia (Recrutamento e Seleção, Readaptação e Aperfeiçoamento Profissional e testes vocacionais); ao mesmo tempo dirigia o Instituto de Psicologia que criou e que fornecia consultoria a empresas. Na parte pedagógica, realizava no período cursos de Psicologia do Trabalho, com o psiquiatra Emílio Mira y Lopes e lecionava as matérias de Psicologia Geral, Psicologia da Personalidade e Psicopedagogia Infantil na Faculdade de Serviço Social de São Caetano e na Faculdade Paulista de Serviço Social. Concomitantemente, passou a atender em psicoterapia médicos, enfermeiros e funcionários do nosocômio, iniciando seu trabalho principal.

Keppe aceitou o convite de Igor Caruso e no Círculo Vienense de Psicologia Profunda tomou contato com as teorias de Adler e de outros autores, que despertaram seu interesse para esse tipo diferente de Psicologia, que entrou no campo humanístico, incluindo em seus estudos também a Filosofia, além da psicopatologia (Bleuler, Pierre Janet, Biswanger, Boss e Kieerkgaard, o próprio tomismo, Aristóteles, Schopenhauer, que influenciou Freud). 
Com a finalidade de se especializar em psicoterapia profunda, Keppe frequentou várias escolas, como a Child Guidance Clinic (Knut Baumgarten), Psicanálise Freudiana, Círculo Vienence de Psicologia Profunda e a Escola de Logoterapia de Viktor E. Frankl (Análise Existencial), tendo optado por esta última para sua formação. Ela é conhecida como a $3^{\text {a }}$ Escola Vienense de Psicoterapia (a $1^{\mathrm{a}}$ é a de Freud, a $2^{\mathrm{a}}$ é a de Alfred Adler). Na General Policlinic de Viena, fez curso de pós-graduação, com treinamento em Logoterapia, diretamente com seu fundador, Viktor E. Frankl. Interessou-se pela preocupação dessa escola com os chamados problemas do espírito ou da alma. Mas a Logoterapia a seu ver carecia de uma metodologia e não podia ser camada uma escola de Psicologia Profunda, tendo um caráter sugestivo, de aconselhamento. Se era certo abordar o problema espiritual, o método de abordagem era superficial (KEPPE, 1988).

Procurou então frequentar outras escolas de psicoterapia, entrando em contato com a Clínica Neuropsiquiátrica do Prof. Hans Hoff, considerado o maior neurologista da Universidade Vienense. Ao mesmo tempo, frequentou as reuniões do Dr. Louis Marksteiner, psicanalista da Sociedade Vienense de Psicanálise, do Dr. Coutsuricki, psicoterapeuta de grupo, e da Dra. Eva Niebauer, analista individual.

Das várias abordagens de psicoterapia a que mais o impressionou foi a psicanálise freudiana em sua metodologia para lidar com os aspectos profundos de personalidade. Em Viena, escreveu sua tese, Psicanálise Integral, buscando unificar as contribuições dos autores: Freud, Frankl, Jung e Adler.

Em 1960, de volta ao Brasil, Keppe dedicou-se exclusivamente ao campo terapêutico psicossomático, no Hospital das Clínicas da Faculdade de Medicina da Universidade de São Paulo, onde coordenou e chefiou o Grupo de Estudos de Medicina Psicossomática junto à Clínica de Moléstia do Aparelho Digestivo ( $2^{\text {a }}$ Clínica do Prof. Edmundo Vasconcelos). Nessa atividade, atendeu clientes em psicoterapia individual e de grupo (doentes do hospital, médicos e estudantes de Medicina), enviados pelas várias clínicas do hospital. Os resultados desse trabalho publicou em seu livro "A Medicina da Alma - Medicina Psicossomática”, Hemus Editora, São Paulo, 1967.

Em 1968, Keppe entrou em contato mais estreito com as pesquisas de Melanie Klein, notando como a questão da inveja (e não da libido) era o elemento fundamental no desenvolvimento das neuroses. Com Wilfried Bion (psicanalista inglês) tornou-se independente da ortodoxia freudiana, elaborando sua própria psicopatologia, baseada no que denominou de teomania. 
Conservou nos seus trabalhos posteriores (até hoje) 1) a metodologia freudiana; 2) teorias de Melanie Klein e Bion; 3) e principalmente as descobertas de Kraepelin, Kohler e Bleuler sobre a megalomania (manias de grandeza). Em 15 de abril de 1970 fundou a Sociedade de Psicanálise Integral na clínica do Prof. Edmundo Vasconcelos afirmando, na Revista de Psicanálise Integral, ed. n 1, 1978: "Ela tem suas bases em Sigmund Freud, Melanie Klein e Wilfred R. Bion, mas aceita todo elemento para seus trabalhos. Sua primeira sede foi situada à Rua D. José de Barros, 51, $3^{\circ}$ andar (em São Paulo, capital) (NETO, 2016).

Em 1996, em São Paulo, Keppe criou o Método Psicolinguístico Trilógico para o ensino de idiomas, que busca conscientizar os alunos dos problemas psíquicos que impedem a aprendizagem, como a megalomania, através do estudo de textos terapêuticos nas línguas estudadas. Esse método é aplicado no Instituto de Línguas Millennium em São Paulo, agora pertencente à Faculdade Trilógica, no qual atuo como docente de línguas: inglês, francês e português para estrangeiros.

O termo teomania já existia na psiquiatria alemã da época, mas somente em casos onde o psicótico sofria de delírios específicos com a temática mística de ser ele Jesus Cristo ou Deus. Keppe (1980) ampliou a compreensão desse termo e o aplicou na base das neuroses vendo-a como uma atitude interior do indivíduo de desejar criar sua própria realidade e até a realidade externa.

Também Thomas Merton (1960), em seu livro A Vida Silenciosa, corrobora com Keppe ao afirmar que "a corrupção íntima, básica, metafísica do homem é sua convicção profunda e ilusória de que ele é um deus e de que o universo está centrado nele" (p. 34). É justamente através da teomania que queremos que só o imaginável fantástico venha a acontecer, deixando de ver e usufruir o que existe realmente.

Nessa atitude delirante o ser humano se acredita com poderes e capacidades acima da sua realidade. Por outro lado, segundo Polanyi (1958), temos um conhecimento subsidiário ligado a um compromisso com a verdade, uma consciência inata e até involuntária que nos mostra o absurdo dessas fantasias de grandeza. Somos deparados com um conflito interior ou até um impasse: ou escolhemos a senda da realidade baseada em evidências captadas por essa consciência (o que exige um bom grau de humildade) e atingimos a maturidade psicossocial, ou a teomania nos domina, causando o desligamento de nós mesmos, e isolamo-nos do mundo e do outro. O outro e o mundo passam a ser o espelho que nos confronta a todo momento colocando em xeque nossas fantasias de perfeição.

Pode-se considerar a teomania como a fonte da censura interna e externa pois condena tudo o que não corresponde à verdade criada pelo sujeito e essa seria "a base de todas as nossas 
dificuldades. Seria como voar sem ter asas ou, pior ainda, construir o mundo interior e o exterior como os imaginamos" (PACHECO, 2001, p. 75).

No ensino de línguas estrangeiras, vemos muitos casos de pessoas que imaginam que podem aprender um idioma com extrema facilidade, em muito pouco tempo, e logo no início do curso se frustram rapidamente - e muitos abandonam as aulas. Ou também o indivíduo que acredita que pode mudar de profissão a qualquer momento e vai desempenhar a nova atividade com a mesma facilidade, como foi o caso do jogador de basquete Michael Jordan ${ }^{5}$ ao achar que poderia jogar baseball com a mesma destreza que o basquete, frustrando-se enormemente. Todo indivíduo teomânico acha que a verdade é o que ele pensa e não algo que independe dele, à qual precisa se adaptar a todo momento.

$\mathrm{Na}$ teomania, o indivíduo não aceita conscientizar-se de sua realidade com seus problemas, antes prefere viver num constante fantasiar-se de perfeito e grande. Neste caso, o indivíduo teomânico tende a se isolar, seja dos colegas de classe, seja de outros professores, porque nota que os outros não os acompanham no engano e não concordam com suas ideias de grandeza.

Dentro dessa perspectiva, a não fruição de nossas subjetividades está ligada a alguma forma de exercício de poder, por estar cerceando as percepções; controlando-se a teomania e exercitando-se a humildade, pode-se trabalhar com mais facilidade as próprias identidades e a dos alunos. Por esse paradigma, a conscientização da teomania poderá nos levar a trabalhar com algo que está entre a identidade e a emoção.

O grande e real desafio agora é abrir um espaço para poder trabalhar com tais aspectos, para se criar uma consciência em torno dos problemas emocionais que inibem nossas subjetividades e, consequentemente, o nosso desenvolvimento. Se a didática da escola também explorar o cultivo da confiança e do trabalho em grupo com atividades de cooperação, as interrelações podem fortalecer o sentimento de pertencimento da comunidade educativa e favorecer uma network de socialização saudável, minimizando os desejos de poder. Dessa forma, é de bastante utilidade estudos nesta seara tão desejosa de propostas coerentes e de real eficácia.

Se levássemos em consideração, por exemplo, o conhecimento tácito de Polanyi, o professor poderia estudar possibilidades de levar o aluno a um nível de conscientização da perda

\footnotetext{
${ }^{5}$ Michael Jeffrey Jordan é um ex-jogador profissional de basquetebol norte-americano, nascido em 1963. É considerado por muitos como o melhor jogador de basquete de todos os tempos e por muitos como um dos mais importantes desportistas masculinos da história. http://esportes.terra.com.br/noticias/0,,OI458809-EI1137,00-Mito+no+basquete+Jordan+foi+um+fiasco+no+beisebol.html Visualização: 30/11/2018
} 
dos parâmetros do conhecimento inato devido ao medo de ver a verdade (teomania). Nesse caso, o aluno deixa de aprender não por uma disfunção qualquer, mas antes por uma rejeição, omissão ou negação ao que tem em seu interior, às suas dinâmicas subsidiárias, suas capacidades de Indwelling.

Assim, o grande problema não é propriamente o de ter ou não uma solução para os problemas emocionais que aparecem no dia a dia, mas a atitude de negar, omitir ou deturpar as possibilidades tácitas que nós professores temos. Existe um obstáculo entre o que a consciência capta e o que a inteligência recebe, motivada pela atitude de teomania, arrogância e megalomania do homem (KEPPE, 2001, p. 16).

A teomania e o desejo de poder, em qualquer esfera individual ou social, são um qualitativo que está no coração do histórico e da política, e os ultrapassa. A teomania elucida atitudes e condutas psicológicas e sociais que participa de relações instáveis de dominação seja em escalas superiores de poder seja em locais de menor poderio ou mesmo no ambiente familiar. O mais agravante é a valorização da teomania ligada à aceleração tecnológica e aos processos identitários atuais, ilimitada pelas sociedades de massa narcísicas, que se reveste de diferentes formas e que produz efeitos avassaladores. Além das novas tecnologias poderem funcionar no movimento de desumanização devido ao isolamento natural provocado pelo uso especialmente de celulares, elas nos dão certos "poderes" de fabricarmos imagens de nós mesmos a nosso belprazer, criando realidades paralelas.

Poderíamos fazer uma pequena análise do desenvolvimento da teomania do indivíduo através das redes sociais midiáticas começando com as selfies, conforme opina Richard Miskolci (2017).

Em menos de uma década, a prática de fotografar a si mesmo para postar em redes sociais ou enviar por mensagens instantâneas tornou-se tão comum para quem possui um smartphone que se naturalizou. A selfie pode ser um bom ponto de partida para começar a refletir sobre a mudança que se passou quando as câmeras fotográficas passaram a ser acopladas aos telefones celulares, incitando seus usuários a voltarem as lentes para si mesmos. A câmera fotográfica não apenas se disseminou como nunca antes e já no equipamento que permite divulgar as fotos, mas ela foi virada para o usuário alçado a paparazzi de si próprio. Se na mídia de massa, marcada predominantemente pela comunicação vertical do broadcasting, os espectadores são incitados a se identificarem com ídolos do cinema e da televisão, na rede, moldada pela horizontalidade, vivem como protagonistas de suas próprias vidas (p.01). 
Parece uma incitação social para a exarcebação do problema de teomania nos indivíduos narcisistas. E, vai mais além, mostrando a competição pela carência de reconhecimento por curtidas:

Os serviços de rede social incitam a postagem de impacto desprovidas de cuidados éticos, checagem de fontes ou respeito ao contraditório. São serviços comerciais que adestram usuários a serem empreendedores de si mesmos, tecnologias multiplicadores de subjetividades em disputa por popularidade. A competição pela atenção está na raiz de boa parte dos conflitos online que se estende para muito além de fenômenos como as "notícias falsas" ou dos haters, usuários especializados em destilar seu ódio contra pessoas ou vertentes políticas. (MISKOLCI, 2017, p. 02)

Com as novas tecnologias, chega-se até mesmo a uma exarcebação teomânica do microfascismo nas redes sociais, mostrando os absurdos a que o mundo chega a partir de atitudes exasperadas de poder, narcisismo e glórias pessoais.

Na suposta horizontalidade democrática da Internet 2.0, voltamos ao estado de natureza. A tecnologia nos restitui à barbárie engendrando um contexto que faz o fascismo da década de 1930 parecer mais simples de compreender. Parafraseando amargamente o título de um livro de Manuel Castells, as redes estão cheias de indignação e ressentimento. As redes sociais são tecnologias de si aptas à disseminação microfascista, não porque seja um fascismo menor ou menos poderoso, ao contrário, porque se trata de um fascismo não mais assentado em macro-referentes como a nação. O microfascismo atual se assenta em identidades e disputas entre e dentro delas. (idem, p. 02)

O mundo real da satisfação, da inteligência, da intuição e da plenitude é um mundo afetivo e abstrativo conseguido através de nossas paixões intelectuais, de nosso consentimento tácito, de nossa partilha de um idioma, de nossa herança cultural, de uma filiação a uma comunidade. Se o indivíduo for muito megalômano, ele vai se distanciar de tudo isso, geralmente com delírios de grandeza, e vai matar o melhor que tem dentro de si. Polanyi (1958) já advertia sobre a "supervalorização" do "surperdesenvolvimento" intelectual em detrimento da verdade e da ameaça disso para a integridade pessoal e social.

A teomania (KEPPE, 2001) e o narcisismo são a porta de entrada para o indivíduo desenvolver doenças mais graves, uma vez que ele perde todo e qualquer contato com a realidade - pois, a característica da conduta narcísica está no fechamento total não em si mesmo, mas na própria máscara, evitando qualquer relacionamento com o mundo exterior - onde evidentemente reside toda sabedoria e a energia escalar que nos dá vida. 
Para um profissional de educação seria muito importante ter essas noções de libertação do objetivismo exacerbado, de forma a trabalhar a partir das convicções do bom, do belo e do verdadeiro, dentro de um sistema de reconhecimento anterior e particular de conhecimento. Para se atingir um nível lógico último e torná-lo explícito, é necessário um processo humilde de prática, no sentido de diminuir a barreira entre o Ser e Pensar.

Assim, precisamos nos munir de ferramentas para o desafio de educar num campo em que geralmente não estamos preparados: o subjetivo; o campo das nossas emoções (pathos); o campo onde mais acontecem desarranjos em sala de aula. Portanto, o estudo e entendimento analítico das inter-relações de um sistema complexo de emoções se faz extremamente necessário para uma percepção, reflexão e intervenção nas brechas pedagógicas.

Uma pergunta pode estar pairando no ar. Mas se as emoções teomânicas se manifestarem fora do campo de percepção dos agentes envolvidos? Como lidar com algo que não domino e nem mesmo reconheço que tenho? Aqui entra a questão da inconsciência. Comecemos pela descoberta de Sigmund Freud sobre o inconsciente.

\subsection{O Inconsciente Freudiano e a Inconscientização Keppeana}

Até o final do século XIX, todas as organizações sociais, econômicas e religiosas em geral tinham a ideia que o ser humano sabia como era, que se conhecia. Com o advento da psicanálise, Sigmund Freud, trouxe uma ideia diferente dessa. Médico nascido no império Austro-Húngaro no ano de 1856, começou a estudar as doenças tidas como enigmas da Medicina, por exemplo, uma cegueira ou surdez a que não correspondia uma causa orgânica. Ele, então, percebeu que a maioria das doenças "intratáveis" pela medicina tinham um fundo causal que não era físico.

Freud, em seu artigo "O Inconsciente” de 1915, justifica a existência de um elemento psicológico chamado de inconsciente (inatingível pelos cânones tradicionais da Psicologia). Tendo como base as ideias de Schopenhauer, acreditava que o ser humano só viveria uma parte da realidade (topo do iceberg); no inconsciente, estariam desejos sexuais reprimidos que dirigiriam a vida humana e que teriam existência por si só; o inconsciente também formaria a base da personalidade humana. Freud criou então um método de investigação desse inconsciente, a Tiefenpsychologie (psicologia da profundidade $=$ psicologia do inconsciente) $\mathrm{e}$ um método de tratamento, a psicoterapia (Psicanálise).

O médico vienense verificou a existência de uma estrutura desconhecida e simbólica que dominava a vida do indivíduo, concluiu que seria importante tratá-la, trazendo-a para a 
consciência, inspirado pelo tratamento de Ana O., Freud descobriu ser possível a cura pela palavra. Analisou o cotidiano, percebeu os lapsos e atos falhos, começou a catalogá-los e constatou que somos trapaceiros da existência pela "ignorância do saber" (FORBES, 2012, p. 160). O psicanalista observou que tanto o obsessivo quanto a histérica mentiam, no sentido que os quadros clínicos são as mentiras sobre o fato da existência do não real. Temos que ter um sentimento de desconfiança de nós mesmos, pois as certezas inconscientizadas têm o condão de nos conservar indefinidamente no engano.

No livro sobre A Psicopatologia da Vida Cotidiana (1901), Freud descreve vários exemplos de inconscientização, mostrando as lacunas que temos nas manifestações conscientes, demonstrando claramente o fator inconsciente. Concluiu que somos regidos pelo que desconhecemos de nós mesmos, sendo assim possível identificar atos inconscientes frequentes no contexto escolar, como esquecer frequentemente o material didático ou o dia de uma avaliação; trocar o dia da aula; cometer diversas rasuras na hora de escrever um texto; entre outros. Não existindo motivos claros, podemos dizer que tais atos são exemplos de inconscientização. Garcia-Roza (2009) explica que "para Freud, a linguagem, longe de ser o lugar transparente da verdade, é o lugar do ocultamento" (p.66).

Na obra A Psicopatologia da Vida Cotidiana (1901), Freud apresenta outro exemplo.

(1) Um amigo me conta a seguinte experiência: "Há alguns anos aceitei ser eleito para a diretoria de certa sociedade literária por supor que algum dia essa organização pudesse ajudar-me a fazer com que se encenasse minha peça, e embora sem muito interesse, participei regularmente das reuniões que se realizavam todas as sextas-feiras. Há poucos meses obtive a promessa de uma representação no teatro de $\mathrm{F}$. e, desde então, passei a me esquecer regularmente das reuniões da sociedade. Ao ler seu livro sobre essas coisas, senti-me envergonhado de meu esquecimento, repreendi-me por ser uma baixeza eu faltar agora, quando já não estava precisando dessas pessoas, e resolvi não me esquecer por nada no mundo da sexta-feira seguinte. Recordeime repetidamente esse propósito até colocá-lo em prática e ver-me postado diante da porta da sala onde se realizavam as reuniões. Para minha surpresa, estava fechada; a reunião havia terminado; é que eu havia errado o dia: já era sábado!” (p.229).

Nesse caso, o nível consciente dizia da importância de estar presente nas reuniões da sociedade em questão, mas o seu desejo inconsciente teve mais preponderância. Ele, no fundo, achava totalmente desnecessária sua presença lá, mas não tinha consciência desses fatores que o dominaram.

Outro caso que achamos importante mencionar do mesmo livro A Psicopatologia da Vida Cotidiana (1901), é de um extravio de um livro: 
(5) Outro caso de extravio merece nosso interesse por causa das condições em que se reencontrou o objeto extraviado. Um homem mais jovem contou-me o seguinte: "Há alguns anos, havia desentendimentos em meu casamento; eu considerava minha mulher fria demais e, apesar de reconhecer de bom grado suas excelentes qualidades, vivíamos juntos sem nenhuma ternura. Um dia, voltando de um passeio, ela me deu um livro que havia comprado por achar que me interessaria. Agradeci-lhe esse sinal de 'atenção', prometi ler o livro, coloquei-o de lado e nunca mais voltei a encontrá-lo. Passaram-se meses em que, de vez em quando, eu me lembrava do livro desaparecido e em vão tentava reencontrá-lo. Cerca de seis meses depois, adoeceu minha querida mãe, que não morava conosco. Minha mulher saiu de casa para cuidar da sogra. $\mathrm{O}$ estado da paciente se agravou e deu a minha mulher uma oportunidade de mostrar seu lado mais positivo. Uma noite, voltei para casa cheio de entusiasmo e gratidão pelo trabalho realizado por minha mulher. Fui até minha escrivaninha e, sem qualquer intenção definida, mas com uma espécie de certeza sonambúlica, abri uma das gavetas, onde, bem em cima de tudo, encontrei o livro há tanto tempo desaparecido, o livro extraviado" (p.147).

Em ambos os casos, ilustra-se o quanto podemos ser regidos pelo que desconhecemos de nós mesmos. Talvez, possamos ter uma pista para o entendimento da atitude de alguns alunos que esquecem frequentemente o material didático e de fazer o dever de casa, trocam os dias das aulas, esquecem o dia da prova e não entendem por que o fazem. Conscientemente querem aprender, mas inconscientemente revelam uma grande resistência, mostrando claramente a intenção interior de rejeição à aprendizagem. Tais ações podem denotar motivos inconscientes em atividade, que dificultam ou impedem a aprendizagem.

Freud mostrou que nossos equívocos, sonhos, esquecimentos, atos falhos e lapsus liguae estariam relacionados a uma intenção de esconder o que se sabe pela consciência. Isso mostra também por que uma pessoa em geral sabe o que é melhor para si e o que deve fazer para progredir, mas não o faz. Ou, por que desiste no meio de um curso de línguas do qual gosta muito e sabe que trará muito retorno e benefícios à sua vida. Conscientemente quer o bem, mas procura e faz o mal, inconscientemente.

De algum modo, podemos verificara que quando um aluno diz não entender o que lhe é exposto e resiste ao máximo ao conhecimento apresentado, pode estar inconscientemente resistindo a alguma consciência latente em seu interior. Um exemplo clássico desse mecanismo de resistência é o aluno que sempre pergunta: "Por que os falantes de inglês mudam os adjetivos de lugar? Por que eu preciso dizer "beautiful woman"? Por que eles trocam? Seria muito mais simples dizer "woman beautiful!" Ele não aceita o que é apresentado, mas busca de todas as formas resistir a assimilá-lo. Mas, não somos vítimas de um inconsciente inato. Vejamos a seguir a diferença importante entre o inconsciente freudiano e o conceito de Norberto Keppe sobre o ato de inconscientizar. 
Para Freud, o inconsciente era uma construção topológica existente no aparelho psíquico, como explica Garcia-Roza (2009).

\begin{abstract}
Esse foi o momento em que o termo "Inconsciente" deixou de ser empregado como adjetivo, designando a propriedade daquilo que estava fora do campo atual da consciência, para ser empregado como substantivo (das Unbewusste), designando um sistema do aparelho psíquico. A substituição da noção descritiva de inconsciente pelo conceito de inconsciente sistemático é um dos momentos fundamentais da construção teórica de Freud. (p.80)
\end{abstract}

Para Norberto Keppe, o inconsciente não é inato, mas gerado por uma luta contra a consciência, tentando escondê-la, criando um mecanismo patológico, denominado por ele de Inconscientização. Para este psicanalista, não existe um inconsciente patológico, mas uma tentativa patológica de esconder o que está em nosso campo de percepção, sem, contudo, obtermos sucesso.

Ao preferir o termo Inconscientização (ato de tornar algo inconsciente), o autor mencionado tira dessa forma a possibilidade patológica de vitimação do indivíduo e tenta compreender o ser humano por um mecanismo mais dinâmico e atuante. Ao negar a visão de um problema, o indivíduo o esconde, criando assim de forma ativa um inconsciente, causando desajustes pessoais e sociais, além de doenças físicas e psíquicas. Keppe explica, em seu livro Auto-sentimento (1977), de maneira precisa esse movimento:

Acredito que a neurose é consequência da vontade consciente em evitar o inconsciente; não que o material "patológico" reprimido seja o responsável, mas devido nossa crença em achar que sempre somos vítimas. Colocamos sempre o mistério no desconhecido, para que tenhamos uma desculpa para não assumir as próprias tendências. Não existem problemas psicológicos, mas, sim, uma forte tendência em considerar os impulsos do interior como inadequados, reprimindo-os violentamente. Começamos a ter dificuldades nessa luta que empreendemos contra a necessidade de conscientizá-los. A maior dificuldade para a evolução é a necessidade que se tem em se assumir. Acredita-se que, evitando a tomada de responsabilidade pelos próprios problemas, eles desapareçam. (p.22)

Quando Keppe (1977) se refere à consciência, não lhe dá um sentido ético ou moral, embora considere que a própria verdade já contenha a ideia de ética. Podemos até confundir ética com cultura ou costumes, mas esse não é o caso. Os conceitos de ética e moralidade social são relativos e mudam de pessoa para pessoa. Todavia, a consciência que sabe distinguir o real do fantástico, a verdade de uma mentira, a boa da má intenção - essa é a consciência universal. É isso que vê toda a realidade e nos liga diretamente à verdade. É instantâneo e eterno; ela existe por si mesma e em nosso eu interior. 
Para Keppe, uma das grandes contribuições de Freud foi mostrar que existe uma intenção inconsciente (oculta) por trás das atitudes e dos pensamentos do ser humano; essa perspectiva, permite entender porque a pessoa, em geral, mesmo sabendo o que é melhor para ela, não cumpre as próprias promessas. O uso de desculpas é muito comum para as atitudes de inconscientização.

Entretanto, considera fundamental saber que o "inconsciente" não é uma "entidade" com vida própria dentro de nós, dirigindo nossa vida, independente de nossa vontade. $\mathrm{O}$ “inconsciente" não é natural. É uma criação artificial de nós mesmos. O que existe por si, realmente, é a consciência. É só aceitá-la. Mas como não queremos ver tudo que ela mostra; negamos, omitimos ou deturpamos o conhecimento, empurrando para fora da consciência o que não desejamos saber.

Desse modo, surge, pela nossa vontade, o "inconsciente", com muito desgaste de energia, por causa do esforço em se inconscientizar. Como depende da vontade, no momento em que resolvermos aceitar a consciência novamente, alcançaremos a sanidade possível. Porém, temos de nos esforçar diariamente para não cairmos no hábito (vício) da inconscientização. Pacheco (2001) nos esclarece:

\begin{abstract}
Essa recusa constante nos leva muitas vezes a um afastamento de nossa consciência e, consequentemente, de nossa sanidade. Eé aí que se iniciam todos os sintomas: angústias, fobias, depressões, doenças orgânicas - como resultado dessa inconscientização forçada. Vemos na consciência algo que nos prejudica, que nos destrói, pois confundimos o perceber com o ser. Fazemos como o avestruz, que esconde a cabeça para afastar o perigo. A consciência não nos destrói - mas através dela percebemos o quanto nós nos prejudicamos. Atente o leitor para o círculo vicioso criado: quando confundimos o ver com o ser, começamos a tentar esconder a visão do que somos e trocamos essa visão por uma imagem, por nós criada, de como gostaríamos de nos ver. (p.150)
\end{abstract}

As pessoas costumam dizer que um louco é aquele que não tem "consciência" do que faz, mas para Keppe, um louco é o homem que nega totalmente a consciência que tem. Nós observamos em nosso trabalho que todo mundo tem, dentro de si mesmo, um conhecimento perfeito do que é, admitindo em maior ou menor grau, o que sabe. Quanto a isso, Cláudia Pacheco (2001) explica:

Quanto mais uma pessoa aceita a percepção de sua atitude patológica, mais sensata ela se torna. Se trabalharmos com a velha ideia da Psicanálise, a partir do princípio de que a pessoa é inconsciente de seus atos, estaremos enfatizando a trapaça deste indivíduo, consequentemente, sua patologia. Não podemos estar doentes por algo que não sabemos, mas por esconder algo que conhecemos. (...) Assim, nossos problemas não vêm do inconsciente, mas da 
atitude errônea que adotamos contra a consciência. Freud costumava dizer que, quando um indivíduo doente lembrava um fato traumático reprimido e o trazia à sua consciência, a cura seria a consequência. Nós diríamos que a partir do momento em que o indivíduo deixa de lutar contra o que ele sabe, ele é automaticamente são. Essa foi uma grande mudança no ponto de vista focal da Psicanálise. De vítimas da inconsciência e da repressão, nos tornamos autores de nossa inconscientização e responsáveis por nossa situação, por causa de nossa desonestidade em relação à nossa consciência. Keppe afirma que o homem não é desonesto porque está doente, mas fica doente porque é desonesto. (p.151)

Um exemplo da incoerência entre o que almejamos e o que fazemos é o fato de uma pessoa dizer que quer trabalhar (isso no mundo consciente), então o despertador toca e ela não consegue levantar para trabalhar (no mundo inconsciente, ela não quer trabalhar). Desse modo, em palavras (conscientemente) ela diz que quer trabalhar, mas em atos (inconscientemente) não o faz. Assim, podemos afirmar que nós, seres humanos, somos muito mais conduzidos pelo que escondemos de nós (pelo que não queremos conhecer de nós mesmos), do que pelo consciente (a parte consciente que aceitamos conhecer).

Keppe nos coloca tête à tête com o nosso núcleo de verdade, deixando de responsabilizar o inconsciente (como se fosse um problema biológico ou genético fatalista), mas antes um trabalho de conhecimento da verdade e, portanto, exigindo nosso engajamento e "a responsabilidade pelo "estranho" que é incorporado pela pessoa." (FORBES, 2012, p. 163).

É comum crianças ficarem doentes às vésperas de viagens ou adultos caírem enfermos diante de acontecimentos ou fatos muito importantes que terão de realizar. Exemplo: aquele aluno ou professor que marca uma atividade em um museu ou um teatro, e fica doente impossibilitando-se de realizá-la.

Esse mundo psicológico inconscientizado é muito importante, porque sem a consideração dele é difícil ensinar e aprender. É preciso saber que todas as pessoas, em maior ou menor grau, têm resistência em agir e fazer o que devem: estudar, trabalhar, entre outras atividades sociais, desejando viver no "princípio do prazer" e não no da realidade como já dizia Freud; assim o aluno preguiçoso, mesmo sem perceber, possivelmente, acha que estudar é uma perda de tempo- essa é a sua verdade-; por isso que ele inventa as mais diversas desculpas e variados subterfúgios para não estudar e não querer que os demais colegas estudem ou que o professor dê aula. Nesse sentido, Keppe (2001) analisa que a doença tem como característica central ausência de consciência, "pois quem está no mal não percebe no que está - só quem está no bem, é que tem consciência do mal que pratica; deste modo podemos dizer que a enfermidade é a inconsciência, ou melhor: inconsciência é enfermidade" (p.53). 
O professor deveria ter apoio e/ou formação sobre esses conhecimentos psicanalíticos, uma vez que isso poderia lhe proporcionar maior domínio e o levaria a ter maior êxito, consequentemente, maior alegria e satisfação, além de ampliar a sua percepção e sabedoria para usar os meios necessários para entrar no mundo psicológico do aluno e poder facilitar o exercício da dança do conhecimento subsidiário (POLANYI, 1958) com o explícito, formando novas incorporações de conhecimentos (Indwelling).

Quando um aluno, por exemplo, entra em sala de aula sem seu material, atrasado e com aquela cara de desânimo e desrespeitando e desprezando a sua aula, poderia possivelmente nos mostrar uma linguagem que seu inconsciente está revelando de oposição aos estudos ou possivelmente uma manifestação de arrogância e complexo de inferioridade, mas sem sua clara percepção por estar em camadas intrapsíquicas de difícil acesso pela razão consciente. Neste sentido, a inconscientização assumiu um papel mais preponderante e dominante, necessitando de uma decodificação (AVELINO; CAMPOS, 2011).

Muitos alunos (inconscientemente) não querem aprender. Temos que trabalhar com esse "não querer" para abrir a percepção deles - porque não há sabedoria sem o conhecimento do próprio interior - e descobrir o porquê deste "não querer". A verdadeira educação está na volta à autenticidade do ser, pelo autoconhecimento e a conscientização. Cada pessoa precisa trabalhar seu interior para mudar o exterior. A mudança deve ocorrer de dentro para fora e não de fora para dentro; só assim estaremos promovendo a real motivação que é a do desenvolvimento humano.

Vivemos de acordo com o que sentimos, pensamos e principalmente fazemos - por esse motivo, se acostumamos a sentir, pensar e agir no bem, pouco a pouco teremos os benefícios que ele produz. Podemos afirmar que aceitar viver no bem é o meio mais direto de estar nele. (KEPPE, 2001).

\subsection{Análises Pedagógicas e Reflexões sobre as Práticas Docentes no Ensino e Aprendizagem de Línguas Estrangeiras}

Em nossa prática educacional, podemos verificar atitudes de alunos e professores que querem muito facilmente um poder desmesurado, achando que a vida é plenamente planificável, justificável e manipulável; anulando-se a espontaneidade em busca de certezas infalíveis. O homem moderno se sente dono de tudo e não conhece seus limites. Essa é a influência nas nossas academias, universidades e escolas. 
O objetivismo nos concedeu uma postura de potência e de controle sobre todas as coisas, proporcionando-nos uma ideia de infinitude sobre a realidade. No entanto, se todo esse conhecimento calculista sobre o objeto desse lugar a uma escuta, a uma experiência receptiva de aproximação e união do sujeito/objeto, poderíamos permitir o inédito acontecer.

Muitas vezes, seria muito mais uma questão de escutar nossos alunos do que ter os melhores métodos e técnicas desenvolvidas para a aprendizagem. Até mesmo, muitas vezes é o silêncio que fala muito mais na busca de uma sintonia com o outro. Geralmente são nesses momentos- de quietude- que acontecem coisas novas e imprevistas. Na poesia, por exemplo, é revelado um mistério escondido na linguagem que nos encanta.

Precisamos, nós, sujeitos, chegar mais perto dos nossos objetos (alunos) e escutá-los, precisamos desenvolver técnicas, projetos, materiais didáticos que levem em consideração a síntese do objetivo/subjetivo, as Indwellings e todo o nosso vasto mundo interior, assim como a abertura de diálogos para análises de fatores impeditivos de nossas significações, tais como a teomania. Tudo isso é um trabalho de ressignificação pedagógica importante a ser realizado.

Precisamos também buscar melhores habilitações no campo extraracional para o entendimento desses fatores psicológicos presentes no ambiente escolar. Nossas políticas públicas deveriam incentivar novos estudos neste campo tão necessário para o desenvolvimento de novos projetos pessoais, sociais, educacionais que fomentem esta lacuna pouco estudada e tão importante que assola nossas escolas.

Para exemplificar melhor o nosso objetivo, consideramos importante colocar aqui algumas falas de alunos que servem como ilustração da proposta desta pesquisa.

\subsubsection{A fala ${ }^{6}$ de dois alunos}

Na condição de docente da língua francesa e inglesa por muitos anos e docente no curso de especialização latu sensu de Gestão de Conflitos em uma faculdade particular também em São Paulo, sempre me interessei pela fala dos alunos. Nesse caso, quis mostrar apenas o envolvimento e a interação humana, por isso entrevistei dois alunos da escola de línguas Millennium em São Paulo. A escola em questão tem uma proposta metodológica humanista, chamada Psicolinguística, a qual se preocupa com os aspectos psicológicos envolvidos na tarefa de ensinar e de aprender.

\footnotetext{
${ }^{6}$ Essas entrevistas são fontes indiciárias ilustrativa que mostram a problemática desta pesquisa.
} 
Os dois alunos escolhidos foram: Denis (22 anos) e Ana (33 anos) ${ }^{7}$. Ambos estudam na escola por mais de 3 anos e apreciam bastante a metodologia. Denis entrou na escola no nível básico levado pelo seu tio, um artista plástico que pediu um desconto na mensalidade devido às dificuldades financeiras que a família atravessava. Denis teve uma adolescência complicada. Sua mãe o teve muito jovem e ele não teve muito contato com o pai biológico. Chegou à escola com sérios problemas de pele e sofria de bronquite asmática.

A entrevista começou quando pedi que ele falasse das aulas que ele assiste na escola. Segue um trecho selecionado:

\begin{abstract}
Aos sábados eu venho para minha aula de inglês. Quando eu acordo, eu tenho vontade de ficar na cama e geralmente acordo com ataque de asma muito forte com nariz soando e tudo... Mas a vontade é de ficar na cama. Eu tento me levantar e quando vou para aula me sinto melhor. Minha vontade era de ficar na cama, mas se eu ficasse na cama e dormisse, provavelmente eu teria ataque de asma o dia inteiro e quando eu me esforço e venho para aula, eu melhoro. Eu fico agindo e não deixo isso ficar no meu corpo porque estou agindo [...].
\end{abstract}

Talvez, esse exemplo mostre quando usamos de nossa teomania (neste caso manifestada pela teimosia em satisfazer as nossas vontades), acabamos nos destruindo e perdendo nossos contatos tácitos/explícitos e ficamos presos em nossas emoções doentias. No caso do Denis, desde que entrou na escola apresentava uma certa apatia, sempre cobrindo a cabeça com um boné ou o capô do casaco. Depois descobrimos que ele era complexado com seu cabelo. Ficava sempre muito quieto e isolado. Como a turma que ele entrou era muito animada, logo os colegas o fizeram se entrosar. Ele foi pouco a pouco se soltando e finalmente se abriu e falou mais dele próprio e de alguns de seus problemas à medida que se identificava com a leitura de trechos de livros que tinham alguma relação com seu problema. No que concerne à língua, inicialmente dava para sentir que ele não gostava muito. Reclamava que a achava chata. Depois de algum tempo, com o entrosamento com os colegas, passou a gostar.

Quando um aluno fala: "Acho inglês uma língua muito difícil porque não tive uma boa base na infância", "Eu acho o inglês uma língua chata, por isso nunca me interessei!", "Não gosto da língua porque é imposta pelo mercado de trabalho", "Não consigo aprender porque o horário não é bom”, “Tem muitos adolescentes na turma”, entre outros, pode ser indício de uma certa resistência inconsciente para não enfrentarem o problema de preguiça, resistência à aprendizagem, mimo, falta de esforço, empenho e procrastinação. Nestes casos, a percepção

\footnotetext{
${ }^{7}$ Os nomes são fictícios de modo a preservar a identidade dos participantes.
} 
perspicaz de cada docente vai ser importante para a percepção de manifestações de teomania e inconscientização manifestas em sala de aula.

Neste sentido, essas maneiras pessimistas de falar podem funcionar como fatores psicopatológicos inconscientizados que bloqueiam a aprendizagem. A percepção deles pode ser ferramenta para se conseguir trabalhar com a real consciência, que é o elemento principal: "ter um defeito não é bom, mas ter consciência dele é fundamental para viver bem” (KEPPE, 2001, p. 45).

Aragão (2007, p. 117) descreve uma pesquisa interessante de vários alunos que tinham baixo desempenho no inglês relacionando-o com a baixa apreciação que tinham de si mesmos; e ao mesmo tempo, acreditavam que os colegas que falavam bem inglês iriam julgá-los e criticálos. Essa é uma situação muito comum em sala de aula, que a psicanalista Melanie Klein chama de Identificação Projetiva ${ }^{8}$. É o processo pelo qual o indivíduo vê suas tendências agressivas, censuradoras e destrutivas no outro (geralmente o mais achegado: pais, marido ou mulher), passando a atacá-lo, como se fosse o culpado de todos os seus problemas (KEPPE, 2001, p. 110).

Tal problema é facilmente identificável nos alunos quando atacam severamente os colegas, os professores e a escola, geralmente sem fundamento. Se um professor tiver conhecimento desses fatores emocionais projetivos teomânicos, possivelmente terá mais ferramentas para uma intervenção pedagógica mais confiante e poderá evitar problemas de disputas desnecessárias no ambiente escolar. Nesse sentido, volto a expressar a necessidade de mais estudos dos fatores emocionais no processo educacional para habilitarmos educadores no âmbito emocional e evitar as identificações com a problemática dos alunos.

Precisaríamos de mais estudos nesta linha para ajudar os educadores no momento que só a objetividade de sua matéria não é suficiente para a resolução de conflitos no espaço de ensino. Um aluno teomânico, por exemplo, que se acha um "reizinho", normalmente mostra ao mesmo tempo uma grande fragilidade interna; se for confrontado, vai tender a se fechar e a pensar que os outros não gostam dele porque ele sabe mais, e que estão com inveja dele. Assim, quando uma pessoa que tem pouca sabedoria se julga sábia, pode ser uma indicação que ela não quer ter percepção da própria falta de conhecimento.

Partindo da minha própria experiência, temos de ir com cuidado, tentando mostrar-lhe o valor dos grandes autores, escritores e artistas, a grandeza das coisas, da natureza e de Deus. E, sobretudo a importância da humildade. Lembrando novamente o exemplo em inglês da

\footnotetext{
${ }^{8}$ Publicação em 1946 na Sociedade Britânica de Psicanálise: Notas Sobre Alguns Mecanismos Esquizoides
} 
palavra "understand" (entender) em que "Under" significa embaixo, e "stand", ficar. Portanto, só o indivíduo que fica embaixo, que tem humildade, consegue entender o mundo e a si mesmo. Assim, Keppe (2010) elucida:

Por exemplo, sempre pensamos que temos a vida dentro de nós e não que estejamos dentro da vida - em uma ideia teomânica de doadores da existência. Esta maneira de pensar leva-nos a uma terrível tensão, causa das doenças, envelhecimento e perecimento rápido. (p.235).

No ambiente escolar, geralmente, o aluno arrogante e teomânico apresenta também muita força. Se o professor conseguir ajudá-lo a se conscientizar, ele pode vir a ser um bom líder social. Através da consciência, podemos incentivar o que há de melhor em cada indivíduo. Na entrevista com Denis, por exemplo, à página 81, quando ele diz: “eu fíco agindo e não deixo isso (asma) ficar no meu corpo porque estou agindo..." mostra o poder da consciência advinda da ação boa (KEPPE, 1977).

Entendemos que o objetivo da docência é promover uma educação consciente para formar cidadãos inteligentes e felizes. Acreditamos na combinação do poder do conhecimento subsidiário de Polanyi (1958) com o mundo explícito, podemos provocar entendimentos antecipados que promovem uma inteligência criativa. E é isso que podemos explorar em nossos alunos, a partir do momento que a psicopatologia for conscientizada.

Devido às alterações incessantes que em cada momento manifestamente renovam o estado das coisas no mundo, as nossas antecipações devem sempre encontrar coisas que, em certa medida, são novas e sem precedentes. Logo, descobrimos que nos baseamos simultaneamente nas nossas antecipações, e na nossa capacidade para as readaptar a situações novas e sem precedentes. (...) a capacidade para continuarmos a enriquecer e avivar o nosso próprio quadro conceptual, pela assimilação de novas experiências, é a marca da nossa personalidade inteligente. (POLANYI, 2013, p. 106)

O aluno teomânico é o tipo que irrita muito a nós professores porque um problema frequente na nossa categoria é a arrogância (teomania). Basta prestar atenção nos intervalos na sala dos professores. A conversa é sempre sobre um aluno difícil, sobre a escola que não lhe dá condições de se desenvolver, etc. Porém, o professor é sempre esforçado, faz somente o correto, realiza sempre mais do que deveria etc. Dificilmente os professores admitem um erro, que precisam melhorar, que seria interessante fazer cursos de aprimoramento ou se submeterem às normas da escola. Dessa forma, como lidar com a megalomania do aluno, se o professor muitas 
vezes é pior que ele? Vai ser impossível e os confrontos serão inevitáveis. Por isso Pacheco (2001) diz:

Ou seja, se o grau de idealização (teomania) que a pessoa faz de si mesma for muito grande, sua censura será também muito forte e não terá tolerância em admitir os seus erros, pois ela gostaria de se ver como um "anjo" ou um "Deus", de preferência, que não comete enganos, nem tem más intenções, maus pensamentos e atos.(p.56)

Podemos concluir que o poder é igual a uma doença psíquica, pois se a pessoa não breca suas atitudes patológicas, cada vez mais se afunda nelas até chegar a um ponto inconciliável, seja com os familiares, com os colegas de trabalho ou com amigos. A cada ano há um grande contingente de professores afastados do trabalho por transtornos emocionais. Pesquisa mostra que $71 \%$ dos profissionais ouvidos já deixaram de trabalhar em razão de problemas psicológicos e psiquiátricos (ARCOVERDE, 2017). O caso é realmente preocupante.

A questão é que somente com nossas argumentações lógicas, só com a preocupação com o ensino de nossas matérias estudadas não se chega a nenhuma resolução de conflitos porque não vamos à origem dos problemas que nos afligem e que afligem os nossos alunos. É por isso que Keppe (2001) diz:

Infelizmente, tenho de admitir que o ser humano está realmente em uma enorme enrascada: quer ser feliz e não consegue; pensa que sabe, mas não sabe; e o pior de tudo é que é extremamente doente, não tendo a menor ideia disso. O que fazer com um ser assim? Enquanto ele não se colocar em seu próprio nível, aceitando a convivência humana normal, não conseguirá ter o equilíbrio necessário para viver (p.04).

Talvez, aqui seja o momento de procurar estabelecer que a alternativa é, como defende Polanyi (1958, p. 108): “assumir as nossas convicções não provadas sem os disfarces objetivistas" e ter a coragem de ajudar nossos alunos sem as convicções do provar científico. É por isso que, talvez, o indivíduo só entenda até onde o seu ser se desenvolveu, desde que colocou um obstáculo entre os seus conhecimentos subsidiários (essenciais) e a sua existência, reduzindo sobremaneira todos os mecanismos de base intuitiva que poderia usar. $\mathrm{O}$ verdadeiro conhecimento se constrói a partir de bases tácitas; quando privilegiamos o raciocínio (objetivismo) e o intelectualismo, desvios começam a ocorrer os quais poderão impedir completamente a percepção do sujeito.

Um aluno certa vez me perguntou porque a língua inglesa usava tanto "do". "Do" na pergunta, "Do" na resposta. Naquele momento, muitas respostas gramaticais vieram à minha 
mente. No entanto, depois de um instante de reflexão, voltei a pergunta para ele e o aluno respondeu que achava a língua mais bonita sem o "do". Naquele momento, percebi que ele sabia usar o ponto gramatical, mas simplesmente o achava feio. Passamos boa parte da aula discutindo a beleza e a estética na língua, poesia, prosa, etc. Foi muito bonito. Eu dei espaço para o aluno e não para minhas explicações gramaticais objetivas. Talvez, esse exemplo possa esclarecer a necessidade de buscar o mistério e magia que há nas coisas pelas quais a objetividade positivista corta.

Se o professor der espaço para compreender a perguntas dos alunos numa atitude mais humilde de escuta, uma explosão de vida acontece e podem-se criar muitas coisas novas. Por isso, Machado (2015) diz:

Particularmente no que se refere aos valores, por exemplo, o papel dos momentos de explicitação é muito discreto, quando comparado com o da assimilação tácita, decorrente da sua vivência efetiva, cultura e prática. Aulas explícitas sobre valores quando não são associadas a uma prática consentânea, esmaecem todo o benefício conceitual e favorecem a consolidação de cinismos de diferentes matizes (p.39).

Muitas vezes, só pelo fato de alguma emoção ser manifesta em sala de aula, de um aluno se manifestar de uma maneira mais calorosa que outros, professores mais rígidos já desqualificam a situação dando a entender que há um desequilíbrio pairando no ar. No entanto, a emoção é um elemento constitutivo de nossa estrutura (DAMÁSIO, 2001)(PACHECO, 2001) e a intransigência com ela é que mostra um desequilíbrio.

O nosso objeto de trabalho é o próprio sujeito, portanto não podemos separar de um lado a razão e de outro o afeto. No campo de ensino e aprendizagem de línguas estrangeiras, junto com o afeto aparecem as emoções negativas que vão se manifestar e nosso trabalho é lidar com elas para que busquemos mais significados nas nossas aulas. Na verdade, nossa atuação como docente, e enquanto instituição escolar, tem papel crucial no reequilíbrio emocional desse aluno.

É o que ficou explícito no trecho abaixo, quando o entrevistado Denis relatou sua chegada na escola; contou sobre seus problemas emocionais e estabeleceu relação entre as melhoras dos seus problemas e a metodologia aplicada na escola em que estuda.

- Entrevistadora: E como você chegou aqui na escola?

(...) E ele (o pai) ficou doente quando eu estava no primeiro colegial junto com a separação da minha mãe. Me abala de certa forma, mesmo sem eu ter a convivência com eles. E eu desenvolvi algumas doenças, 
tipo de pele que é totalmente emocional. Todos os meus problemas de saúde são mais para o lado emocional. Bronquite, por exemplo, é totalmente emocional. Se eu fico nervoso ou ansioso, dá um ataque e este problema de pele que é totalmente emocional. Daí eu entrei aqui na escola, quando isso começou a desaparecer. Esses problemas todos deu uma recuperada!

- Entrevistadora: Como você explica passo por passo como isso aconteceu?

Eu acho que quando eu entrei aqui eu tinha todos aqueles problemas. Aqui a escola foi tratando desses problemas com a consciência de seu lugar no mundo, com a sua consciência do seu relacionamento com a sociedade e esses problemas eu percebi que nem tudo assim... todos os problemas eram causados pelas outras pessoas, mas também por mim. Numa tentativa de esconder esses problemas. Acho que foi isso, mais ou menos, tratando esses problemas numa consciência maior de mim mesmo.

As marcas na minha pele é (são) bem claro. Eu tinha questões como mesmo e tratando esta consciência, entendendo que talvez eu estivesse atacando o meu próprio corpo, é que eu consegui ver o problema e consegui tratar dentro de mim mesmo. Esse problema que estava aparecendo em minha pele era um problema comigo mesmo. A partir do momento que eu percebi que era dentro de mim mesmo, que eu estava atacando o meu próprio corpo. Daí foi isso, eu comecei a me curar de dentro para fora.

- Entrevistadora: Como foi isso?

Não foi de um dia para o outro.

- Entrevistadora: Como você chegou a esta visão?

Foi em algumas aulas, principalmente quando você trabalha mais o relacionamento com as outras pessoas e como isso te afeta e como eu afeto os outros. Ah.. eu acho que foi isso.

Outro exemplo de inconscientização e sua presença na aprendizagem é o trecho da fala da aluna Ana, também coletada para esta pesquisa. Verifica-se que a escolha do texto didático trabalhado na aula de ensino de língua suscita uma reflexão por parte da aluna.

Uma semana depois da aula de inglês em que havíamos estudado um texto curto sobre associação de ideias de Karl Gustave Jung, Ana nos contou o relato abaixo:

- Entrevistadora: Você pode falar um pouquinho da situação na aula, esse exemplo que você deu sobre o seu pai? O que aconteceu? 
- A gente estava numa aula. Num exercício de associação onde você pediu para que a gente escrevesse 5 palavras e fizesse uma rápida associação dessas 5 palavras com 5 outras palavras, sem que a gente pensasse muito, sem que a gente bloqueasse nenhuma das palavras. E a primeira palavra que eu disse foi "pai”. E a primeira associação livre que eu fiz foi "ausente". Aí para mim aquilo era muito claro: meu pai era ausente. E aí depois que o exercício foi se desenrolando e ouvindo outras pessoas, eu mergulhei neste pensamento, tentar entender porque a ausência dele e eu o culpei a vida inteira por estar ausente e percebi que, talvez, eu estivesse ausente. E que a responsabilidade disso fosse minha e não dele. Então, no dia seguinte, eu liguei para ele e falei: "Olha, aconteceu isso. Eu fiz o exercício e queria conversar com você porque eu sinto você muito ausente e ele disse: "Mas eu tô tentando contato com você! Eu te mando o WhatsApp, mas por alguma razão o meu WhatsApp não chega! E aí eu me dei conta que eu tinha bloqueado ele no WhatsApp. Então, jamais ele ia conseguir falar comigo. Seja por telefone, seja por mensagem porque ele não tinha como chegar a mim. E de fato como a gente não se vê e não mora perto. Não era coisa que dava para ir um na casa do outro. Então, assim, as poucas maneiras que ele tinha de me contatar, eu bloqueei e aí deu essa ausência e o buraco deste tamanho e aí percebi que a responsabilidade não era dele, era minha.

- Entrevistadora: Quem era ausente, na realidade?

- Eu! Totalmente eu! Engraçado que meu nome é Ana Batista Gomes. E o "Gomes" é dele (do meu pai) e eu evito usar. Então, agora eu sou Ana Batista Gomes!

Encontrar maneiras de suscitar consciências de nossas problemáticas, em uma ressignificação pedagógica que permita a visão de um resgate de nossas possibilidades interiores, deve ser o interesse de qualquer educador.

Polanyi (1958) assumiu como importância vital uma nova maneira de ver o sujeito e respeitá-lo em sua integridade, já que o julgamento cognitivo depende, no final das contas, de elementos conhecidos apenas tacitamente por uma mente em ação, e são conhecimentos pessoais não articuláveis em palavras, resgatando a posição epistemológica ignorada na modernidade que é justamente o coração da filosofia dele.

Apesar de colocar a ação como ponto importante de conexão entre o conhecimento tácito e o explícito, ele não gostava de ser confundido com o pensamento pragmático americano (John Dewey e outros) em ter um ímpeto de querer resolver um problema em um tipo de 
praticidade, mas preferencialmente uma paixão em atingir compreensivos significados em qualquer situação em que um indivíduo estivesse envolvido. Segundo Prosch (1986).

Ele via os organismos como centros primordiais de busca de significado, já orientados para o objetivo de encontrar ou alcançar entidades holísticas estruturalmente ordenadas, dentro e fora de si, quer fossem ou não necessários todos esses conjuntos para restaurar a atividade contínua (pp. 7-8). (Tradução minha.)

É neste sentido que Aragão (2008) coloca a necessidade de elementos extracartesianos no ensino aprendizagem de línguas estrangeiras:

Necessita-se de um processo de autoconhecimento no qual se possa questionar sua própria conduta em relação ao seu meio contextual e agir em conexão a ela, com a compreensão de uma experiência e desejo. "Durante essa atividade o aluno passa a ser o autor de sua própria história, ao compreendê-la em sua forma processual (p. 2660).

Atentando para um contexto de correção de pronúncia de inglês em sala de aula, por exemplo, os professores devem levar em consideração que no momento em que o aluno está tentando se manifestar numa língua estrangeira, é muito importante que o professor não o corrija continuamente porque pode justamente inibir a parte mais subjetiva dele. Portanto, nesses momentos em que o aluno está exercitando a língua - mesmo que com erros-, que a aprendizagem está sendo processada; se o professor corrige demais, numa tentativa objetiva de fazer o estudante falar corretamente, vai cair no engano de tolher o desempenho do aluno (LEFFA, 2008).

Vemos que nos novos tempos da Pós-Modernidade, plena de novas perspectivas futuristas e disruptivas dos padrões da modernidade, somos impelidos a uma postura de cautela diante do novo que está a nossa frente. Souza Santos (1988) nos apresenta a seguinte perspectiva para o futuro:

A ciência moderna legou-nos um conhecimento funcional do mundo que alargou extraordinariamente as nossas perspectivas de sobrevivência. No futuro não se tratará tanto de sobreviver como de saber viver. Para isso é necessária uma outra forma de conhecimento, um conhecimento compreensivo e íntimo que não nos separe e antes nos una pessoalmente ao que estudamos. A incerteza do conhecimento, que a ciência moderna sempre viu como limitação técnica destinada a sucessivas superações, transfora-se na chave do entendimento de um mundo que mais do que controlado tem de ser comtemplado. Não se trata do espanto medieval perante uma realidade hostil possuída do sopro da divindade, mas antes da prudência perante um mundo 
que, apesar de domesticado, nos mostra cada dia a precariedade do sentido da nossa vida por mais segura que esteja ao nível da sobrevivência. A ciência do paradigma emergente está parecendo ser mais ligada a fatores subjetivos que objetivos. A qualidade do conhecimento afere-se menos pelo que ele controla ou faz funcionar no mundo exterior do que pela satisfação pessoal que dá a quem a ele acede e o partilha (p.68).

Cada vez mais se faz necessário que o processo educacional atual leve em conta os aspectos particulares do conhecimento subjetivo e debata os impeditivos emocionais de alunos e professores manifestos em sala de aula. A nossa contribuição na discussão aqui foi mais especificamente a teomania e o processo de inconscientização na seara da síntese da objetividade/subjetividade. 


\section{CONSIDERAÇÕES FINAIS}

A minha experiência docente; as dificuldades relatadas por colegas da mesma profissão; e, a observação da relação com o conhecimento de alunos, amigos e familiares fizeram-me refletir e direcionar o escopo da minha pesquisa para essa área dos bloqueios emocionais no ensino/aprendizagem de línguas estrangeiras- uma área ainda pouco estudada. Na busca de respostas às minhas indagações, comecei a constatar a influência forte que a objetividade exerce sobre nossa maneira de ser e estar no mundo, de forma a produzir diversos significados que minam a própria criatividade dos sujeitos.

Passando pelo estudo de Vico e Pascal já visualizamos considerações interessantes que apontam outros modos de se compreender a realidade. Ao dialogarmos com os textos de Michael Polanyi (1958) descobrimos verdadeiramente uma teoria que problematiza diversas questões importantes para este trabalho. Afinal, não há como falar de emoções sem considerar nossas subjetividades, elas são transformadoras e nos constituem enquanto sujeitos. Este próprio trabalho de dissertação me transformou, pois tive que passar por um processo íntimo de partilha de ideais e de vivências.

Esse processo de transformação começa na síntese representada pelos estudos de Polanyi (1958), que considera a importância do conhecimento pessoal tácito para que ocorra incorporações (Indwelling) e se manifeste o conhecimento explícito. De acordo com Polanyi (1958), não há outro caminho a seguir se quisermos salvar a ciência e o ser humano, a não ser levarmos em consideração os aspectos interiores subsidiários de conhecimento - o que nos impede de vivê-los - ou, estaremos fadados a uma educação gerada pela excessiva consideração do objetivismo em nossas escolas e universidades. Talvez seja o momento de articularmos, mesmo que minimamente, elementos de composição de uma metodologia ou um caminho de explicitação de nosso conhecimento pessoal tácito. É nele que encontraremos competências hábeis, já que para Polanyi, o conhecimento é latente e somos "subsidiariamente conscientes" (1958, p. 60) dele, mas não podemos incorporá-lo de maneira objetiva.

Delineia-se, portanto, a necessidade de uma metodologia que dê chances e oportunidades para que alunos e professores possam readequar seus quadros conceituais e possam desenvolver paixões intelectuais a partir do seu comprometimento com elas. Por estarmos lidando com aspectos subjetivos - subsidiários-, e por não termos um controle intelectual total sobre as combinações e antecipações, não podemos contar com metodologias que se contentem apenas com análises racionais, pois assim estamos diminuindo a percepção e a intuição e todo esse conhecimento subsidiário. Também não é um laissez-faire didático sem 
nenhuma objetividade. Na ausência de modelos pré-determinados, julgamos que a confiança deve estar em nossas bases subsidiárias não articuladas de nossa inteligência, como um “conhecer competente" a partir de um "fazer hábil” (POLANYI, 2013, p. 67). E assim trabalhar com elementos que instaurem competências subjetivas.

No campo do ensino e aprendizagem de línguas estrangeiras, percebemos que os obstáculos à aprendizagem (bloqueios) são apresentados por uma grande quantidade de alunos. Logo, nossa responsabilidade como professores tem de ir além da transmissão de conhecimentos explícitos. Nós temos que ser promotores de incorporações de novas ideias (Indwelling) pelos alunos, fazendo com que eles sejam "caçadores de significados" e pensadores críticos.

O professor de línguas, levando em conta os aspectos mencionados nesta pesquisa, deve permitir que o seu aluno erre uma, duas, três vezes; deixando espaço para o estudante experimentar a dança do seu nível tácito com o explícito. É melhor o aluno errar, mas adquirir confiança, do que saber pronunciar muito bem palavras esparsas e não conseguir se expressar na língua estudada. Em sala de aula, precisamos pensar que temos um conhecedor tácito em nossa frente que busca o conhecimento explícito (falar a língua). Nossa possível função deverá ser a de identificar e valorizar esses conhecimentos subsidiários, colocá-los em ação para a busca da expressão explícita. Todos nós carregamos uma gama de conhecimentos subsidiários muito grande, mas muitos não sabem como expressá-los ou os expressam de maneira mínima, não tendo noção de toda a possibilidade maior.

Em um determinado momento, notamos que não era apenas uma questão de encontrar uma metodologia mais adequada para promoção de Indwellings (incorporações) e, por conseguinte, promover a aprendizagem. Notamos que a questão seria melhor reformulada se entendêssemos os fatores emocionais que nos impedem de termos maior contato com o nosso interior (subsidiário), promovendo nossas paixões intelectuais.

Notamos, portanto, a necessidade de buscar a leitura de outros autores, como Alfred Adler para entender a noção de Complexo de Inferioridade e assim construir ideias para que alunos e professores possam se conhecer mais, e possam aprender e ensinar de maneira mais harmônica. Compreendemos, então, que o aluno imbuído de teomania pode ignorar a ideia de limites e dessa forma pode mostrar uma postura poderosa, incoveniente. A vontade de resistir a qualquer bem ou progresso apresentado ou restrição a seu querer, o reduz a uma identidade que não lhe convém, impedindo-o de ter uma atitude de resiliência e de consciência diante de suas incapacidades (ADLER, 1977). Devemos, portanto, nos debruçar mais intensamente em 
estudos que possibilitem a identificação e análise da influência de sentimento de inferioridade em nossos alunos e em nós mesmos, que provoca seu oposto (megalomania).

Já em Norberto Keppe (1980), percorremos um caminho mais profundo ao perceber que o nervosismo, a neurose, a psicose e as doenças físicas são causadas por uma batalha que levamos a cabo contra a verdade, a beleza e a bondade. A partir dessa composição, constatou uma base de cunho megalômano no indivíduo, necessitando de um certo grau de humildade para retornar ao contato com esse interior bom.

$\mathrm{Na}$ teomania, o indivíduo não aceita conscientizar-se de sua realidade, com seus problemas, antes prefere viver num constante fantasiar-se de perfeito e grande. Neste caso, o indivíduo teomânico tende a se isolar, seja dos colegas de classe, seja de outros professores porque nota que os outros não acompanham e não concordam com suas ideias de grandeza.

Esse sentimento patológico da teomania ao mesmo tempo que dá uma sensação de poder ao seu portador, também pode causar um violento sentimento de frustração ao ser impedido de realizar qualquer coisa, causando muita tensão no ambiente. Entendemos que se um educador tiver um certo grau de humildade, souber identificar essas atitudes teomânicas em si próprio, nos alunos e nos colegas, já produzirá ações com efeitos muito mais positivos no ambiente escolar e acadêmico (KEPPE, 2001, p. 11).

Ao ensinar uma língua estrangeira, deparamos com dificuldades mais claramente expressas pela natureza inerente de ensinar línguas. O aluno tem que se expressar numa outra estrutura linguística que não é a materna, forçando-se a lidar com uma contingência de estrutura grande e nova que ele não domina; isso o coloca em cheque a cada momento com suas inferioridades.

Encontramos alunos que se frustram muito facilmente e dizem que não são bons em línguas, que têm pânico ao ter que falar com um nativo, que se veem arrasados quando não entendem uma conversa simples e logo vem "aquele branco" indesejado. Quando estudam anos a fio e não conseguem articular expressões simples da língua estudada. Tudo isso é o mundo das emoções dominando o indivíduo sem muitas vezes ele ter nenhuma razão aparente objetiva para tal.

Podemos falar, então, de um método que propicie a análise e o estudo dos impedimentos de nossos indwelling e a consequente problemática emocional? Esse parece ser um território quase inexplorado, carecendo urgentemente de novas pesquisas. No entanto, vale frisar mais uma vez que uma metodologia objetiva para esse campo nos afastaria justamente dos nossos estudos e seria até mesmo contraditória. Precisamos, portanto, pensar em uma outra via de ação. 
O professor tem uma grande missão, pois ele acaba entrando na vida da criança, do jovem e do adulto e o seu poder de transformação é absoluto. Partindo do nosso entendimento dos valores subsidiários, aumenta o nosso compromisso nas mudanças de nossos alunos. Os desafios são grandes, mas quando ajudamos uma criança, e ela coloca para fora as suas capacidades tácitas desenvolvendo-se, especialmente quando trabalha seus problemas emocionais, isso nos faz querer vencer os desafios e acreditar no ser humano. Isso é o que nos leva adiante como educadores.

Partindo da frase de Keppe (2001, p. 5), já mencionada anteriormente: “O mais importante é o conhecimento daquilo que impede o próprio conhecimento", vemos que o autoconhecimento não é mais uma possibilidade de desenvolvimento, é muito mais um modo de sobrevivência no mundo atual. É nesse sentido que é necessário também discutir o fator inconsciente no processo de ensino/aprendizagem também de línguas estrangeiras, já que no campo educacional, esse assunto assume uma importância maior pois os elementos interiores e exteriores têm uma atuação na conformação da identidade e do caráter do indivíduo. Portanto, o papel do professor, e de qualquer educador, deve ser principalmente de um investigador para estudar e tentar descobrir por que o aluno não está indo bem, e possivelmente verificar os fatores inconscientizados por trás dos problemas de aprendizagem.

Não é mais possível apresentar as desculpas dantes aceitáveis para os nossos infortúnios tais como: "foi um trauma de infância", "foi por causa de meu pai", "só se for inconsciente" (visto como impulsos não controláveis e tendências desconhecidas) etc. A irresponsabilidade inconsciente não está mais encontrando muito espaço atualmente. Como literalmente o tempo está indo muito rápido, e pela inviabilidade de vacilarmos em nossas existências, está surgindo a necessidade de uma responsabilidade maior na participação mais direta e atuante no que tange à consciência plena (FORBES, 2012).

Assim, constata-se a necessidade de estudos mais aprofundados sobre a subjetividade para que entendamos melhor o funcionamento de nosso conhecimento para além da objetividade. Ou seja, compreender quais os fatores emocionais que impedem o acesso aos nossos níveis subsidiários de apreensão da realidade para realizar nossas paixões intelectuais e por consequência viver uma vida mais saudável.

Seria, portanto, muito importante termos mais estudos e propostas sobre o assunto para contribuir com o desenvolvimento de mecanismos de percepção emocional para atingirmos o nosso fantástico conhecimento subsidiário. As ideias desta dissertação apontam alguns caminhos para uma longa e complexa discussão necessária ao aprimoramento e direcionamento 
das práticas pedagógicas para o bem-estar nas nossas instituições de ensino, carentes de entendimentos no âmbito emocional. 


\section{REFERÊNCIAS}

ABBAGNANO, N. Dicionário de filosofia. 4. ed. Martins Fontes: São Paulo, 2003.

ADLER, A. L'éducation des enfants. Éditions Payot: Paris, 1977.

ARAGÃO, R. A dimensão afetiva no ensino e na aprendizagem de L2. Revista Múltiplas Perspectivas em Linguística, p 2655, 2008.

ARAGÃO, R. Cognição, emoção e reflexão na sala de aula: por uma abordagem sistêmica do ensino/aprendizagem de inglês. Revista Brasileira de Linguística Aplicada, v. 5, n. 2, p. 101-120, 2005.

ARAGÃO, R. São as histórias que nos dizem mais: emoção, reflexão e ação na sala de aula. 2007. Tese (Doutorado em Estudos Linguísticos) - Faculdade de Letras, Universidade Federal de Minas Gerais, Belo Horizonte, 2007.

ARANTES, A. A. (org.). Afetividade na Escola. Alternativas Teóricas e Práticas. São Paulo: Summus Editorial, 2003.

ARCOVERDE, L; FRANCO, E; GALVÃO, D; PRADO, G. Número de professores afastados por transtornos em SP quase dobra em 2016 e vai a 50 mil. GloboNews. São Paulo, nov. 2017.

AVELINO, B. A.; CAMPOS, C. A Terapia em Sala de Aula. 2. ed. São Paulo: Próton Editora, 2011.

CARDOSO, L.; CARDOSO, P. Para uma revisão da teoria do conhecimento de Michael Polanyi. Revista Portuguesa de Pedagogia, ano 41-1, Coimbra, 2007. Versão online. Disponível em: https://digitalisdsp.uc.pt/bitstream/10316.2/4527/1/5\%20-\%20Para\%20uma\%20revisao\%20da\%20teoria\%20 do\%20conhecimento\%20de\%20Michael\%20Polanyi.pdf. Acesso em: 25 set. 2018.

CUNHA, W. Q. A História em Vico e suas Contribuições à Contemporaneidade In: III Encontro Nacional da Pesquisa na Graduação em Filosofia da UFPA. Anais [...]. Universidade Federal do Pará, 2013.

DAMÁSIO, A. R. O Erro de Descartes. São Paulo: Companhia das Letras, 2001.

DARWIN, C. Autobiografia de Charles Darwin. Rio de Janeiro: Contraponto, 2000.

DESCARTES, R. As Paixões da Alma. São Paulo: La Fonte, 2012.

DESCARTES, R. Regras para a Direcção do Espírito. Lisboa, Portugal: Edições 70, 2002.

DUBOC, A. P. M. Avaliação da aprendizagem de línguas e os multiletramentos. Estudos em Avaliação Educacional, São Paulo, v. 26, n. 63, p. 664-687, set./dez 2015. 
DUBOC, A. P. M. Atitude Curricular. Letramentos Críticos nas Brechas da Sala de Aula de Línguas Estrangeiras. São Paulo: Paco Editorial, 2015.

FORBES, J. Inconsciente e Responsabilidade Psicanálise do Século XXI. São Paulo: Manole, 2012.

FREUD, S. Sobre a Psicopatologia da Vida Cotidiana. Porto Alegre: L\&PM Editores, 2018.

KEPPE, M.A. Vida e Obra de Norberto Keppe - A História da Trilogia Analítica. São Paulo, Proton Editora, 1988.

KEPPE, N. A origem das enfermidades: psíquicas, orgânicas e sociais. 2. ed. São Paulo: Proton Editora, 2001.

KEPPE, N. Auto-sentimento. São Paulo: Proton Editora, 1977.

KEPPE, N. O reino do homem. 2. ed. São Paulo: Proton Editora, 2010.

KEPPE, N. A Libertação pelo Conhecimento - A Idade da Razão. 2. ed. São Paulo: Proton Editora, 2001.

KEPPE, N. From Freud to Victor Frankl. São Paulo: Proton Editora, 1980.

LEFFA, V. (org.). O Professor de Línguas Estrangeiras Construindo a profissão. 2. ed. Pelotas: EDUCAT Editora da Universidade Católica de Pelotas, 2008.

LISPECTOR, C. A Descoberta do Mundo. Rio de Janeiro: Rocco, 1999.

MACHADO, N. J. Epistemologia e didática. São Paulo: Cortez, 1995.

MACHADO, N. J. Educação Competência e Qualidade. São Paulo: Escrituras, 2009.

MACHADO, N. J. O Conhecimento como um Valor. São Paulo: Editora Livraria da Física, 2015.

MACHADO, N. J. Objetividade e subjetividade na construção do conhecimento. In:

ARANTES, Valéria Amorim (Org.) Afetividade na escola - alternativas teóricas e práticas. São Paulo: Summus, 2003.

MARINA, J. A. Teoria da Inteligência Criativa. Rio de Janeiro: Guarda Chuva, 2009.

MERTON, T. A Vida Silenciosa. Petrópolis, Rio de Janeiro: Ed. Vozes, 1960.

MISKOLCI, R. Notas sobre o Microfascismo nas Redes Sociais. Revista Cult Site. São Paulo, SP, 2017. Disponível em: https://revistacult.uol.com.br/home/redes-de-ressentimentonotas-sobre-o-microfascismo-nas-redes-sociais/. Acesso em: 06 mar. 2018.

MORENO, Ana Carolina. Brasil cai três posições em índice de proficiência em inglês e sai do top 40. Site. Revista Educação Online. São Paulo, 04 nov. 2015. Disponível em: 
https://g1.globo.com/educacao/noticia/apesar-de-pontuacao-menor-brasil-sobe-em-rankingde-proficiencia-em-ingles.ghtml. Acesso em: 17 ago. 2018.

NETO, J.O.C.. A Odisseia da Trilogia, Vol. I, A Origem. Ed. do Autor, São Paulo, 2016

PACHECO, C. A Cura Pela Consciência - Teomania e Estress. 4. ed. São Paulo: Editora Proton, 2001.

PACHECO, C. ABC da Trilogia Analítica. 11. ed. São Paulo: Editora Proton, 2016.

PACHECO, C. Psicoterapias Alienantes. 2. ed. São Paulo: Editora Proton, 2005.

PASCAL, B. Pensamentos. São Paulo: Abril Cultural, 1973.

POLANYI, M. The Tacit Dimension. Gloucester: Peter Smith, 1983.

POLANYI, M. Conhecimento Pessoal : por uma filosofia pós-crítica. Portugal, Inovatec, 2013.

POLANYI, M. Personal knowledge: towards a post-critical philosophy. London: Routledge \& Kegan Paul, 1958.

POLANYI, M. e PROSCH, H. Personal knowledge: a critical exposition. Albany, NY, 1986.

POPPER, K.R. La Lógica de la Inverstigación Científica. Madrid, Editorial Tecnos, S.A., 1980.

POPPER, K. R. Conhecimento Objetivo. São Paulo, Edusp/Itatiaia, 1975.

POPPER, K. R. Em Busca de um Mundo Melhor. Portugal: Fragmentos, 2006.

ROESER, R.; ECCLES, J. Handbook of Development Psychopathology. 2nd. Ed. New York: Plenum Publishers, 2000.

SOUZA SANTOS, B. A Crítica da Razão Indolente, Contra o Desperdício da Experiência. São Paulo: Cortez Editora, 2011.

SOUZA SANTOS, B. Um discurso sobre as ciências na transição para uma ciência pósmoderna. Estudos Avançados, v.2, n.2, São Paulo, maio/ago. 1988.

SOUZA, V. A História e a Filologia na Ciência Nova de Giambattista Vico. Fragmentos, n. 33, p. 293-307, Florianópolis, jul-dez. 2007.

TERRA, R. Mito no basquete, Jordan foi um fiasco no beisebol. Site. Terra Esportes. Online. São Paulo, 04 nov. 2015. Disponível em: 2 de janeiro de 2005:

http://esportes.terra.com.br/noticias/0,,OI458809-EI1137,00-

Mito+no+basquete+Jordan+foi+um+fiasco+no+beisebol.html. Acesso em: 30 dez. 2018. 
VICO, G. Princípios de (uma) Ciência Nova (Acerca da Natureza Comum das Nações). Editora: Victor Civita, 1974.

WALlON, H. Les Origines de la Pensée chez l'Enfant. París: Universitaire de France PUF, 1989.

YASUKATA, Y. English as an international lingua franca: from societal to individual. World Englishes, v. 28, n. 2, May. 2009.

ZEMBYLAS, M. Challenges and Possibilities in a Postmodern Culture of Emotions in Education. Interchange, v. 37, n. 3, p. 251, 2006. 